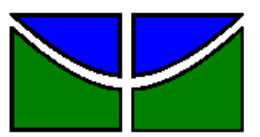

Universidade de Brasília (UnB)

Faculdade de Economia, Administração, Contabilidade e Gestão de Políticas Públicas (FACE)

Programa de Pós-graduação em Administração (PPGA)

Curso de Mestrado Acadêmico

\title{
O INCENTIVO DE GOVERNO E DE ESCOLAS À COPRODUÇÃO DO ENSINO FUNDAMENTAL PÚBLICO POR FAMILIARES DE ALUNOS
}

GUILHERME FERREIRA SOARES

Brasília - DF

2017 
Universidade de Brasília (UnB)

Faculdade de Economia, Administração, Contabilidade e Gestão de Políticas Públicas (FACE)

\section{O INCENTIVO DE GOVERNO E DE ESCOLAS À COPRODUÇÃO DO ENSINO FUNDAMENTAL PÚBLICO POR FAMILIARES DE ALUNOS}

\section{GUILHERME FERREIRA SOARES}

Projeto de Dissertação de Mestrado submetido ao Programa de Pós-Graduação em Administração da Universidade de Brasília como requisito parcial para a obtenção do grau de Mestre em Administração.

Aprovado pela seguinte Comissão Examinadora:

Prof $^{a}$ Dr $^{a}$ JOSIVANIA SILVA FARIAS

Orientadora (Universidade de Brasília - PPGA/UnB)

\section{Prof $^{a}$ Dr $^{a}$ MARIA ELENA LEÓN OLAVE}

Examinadora Externa (Programa de Pós-Graduação em Administração da Universidade Federal de Sergipe- PROPADM-UFS/SE)

Prof. Dr. ADALMIR DE OLIVEIRA GOMES

Examinador Interno (Universidade de Brasília - PPGA/UnB)

$\operatorname{Prof}^{\mathrm{a}} \mathrm{Dr}^{\mathrm{a}}$ MARINA FIGUEIREDO MOREIRA

Examinadora (Universidade de Brasília - PPGA/UnB) Membro Suplente 


\section{RESUMO}

Esta dissertação se propôs a identificar como o incentivo à coprodução da educação pública tem se dado pelo governo e escolas, e investigar a influência do perfil sociodemográfico da família nas formas de coprodução. Os incentivos foram levantados por meio de pesquisa documental acerca da legislação vigente, e de 10 entrevistas em profundidade com gestores escolares, com amostragem definida por saturação teórica. Os gestores escolares foram questionados quanto às formas de coprodução promovidas pelas escolas. Posteriormente, com o objetivo de identificar a influência do perfil de familiares de alunos nas formas pelas quais coproduziam e/ou estavam dispostos a coproduzir, foi realizado um survey com 269 familiares de alunos de diversas regiões administrativas do Distrito Federal, analisadas a partir de regressão linear e logística. A coleta de dados foi realizada entre os meses de maio e dezembro de 2016. Identificou-se um amplo aparato legislativo que incentiva a coprodução provendo benefícios aos familiares que apoiam os alunos no processo educativo, como o Programa Bolsa Família; mas pincipalmente definindo punições para os que não o fazem, como perda da tutela; e, ainda, garantindo ambientes de participação, como conselhos escolares e reunião de pais. As escolas buscam incentivar a coprodução com a utilização de políticas governamentais e promovendo aproximação de familiares com a escola, como eventos, mas também lançando mão de aparatos legais em casos de negligência, particularmente em relação à coprodução de suporte básico, forma de participação da família não identificada nos estudos realizados em países europeus. A pesquisa com familiares mostrou que a coprodução do tipo pedagógica é a mais frequente, seguida da coprodução social, e que não há diferença significativa entre a frequência da coprodução individual e a coletiva. A coprodução individual é influenciada principalmente pelo nível de instrução do familiar e pelos hábitos domésticos, em especial o hábito de leitura e teatro, indicando que políticas de incentivo à educação superior podem ter efeitos positivos na coprodução da educação básica, em especial no suporte econômico e pedagógico. Como contribuições, a pesquisa traz o entendimento de como a coprodução de serviços públicos ocorre em países em desenvolvimento, e de como o perfil do usuário do serviço impacta a coprodução da educação pública. Os resultados criam uma base sobre a qual políticas públicas de incentivo à coprodução podem ser formuladas e implementadas de forma mais consciente acerca de fatores relevantes à coprodução da educação pública por familiares de alunos.

Palavras-chave: coprodução de serviços públicos; educação pública; setor público; governo. 


\begin{abstract}
This study aims to identify how the government and schools has encourage the co-production of public education by, and to investigate the influence of the sociodemographic profile of the families of students in the forms of coproduction. The data gathering happened at the end of 2016. The incentives were identified through documentary research on the current legislation, and 10 in-depth interviews with school managers, using theoretical saturation as sampling method. The school managers were questioned about the forms of coproduction promoted by the schools. In order to identify the influence of the family profile of students in the forms of coproduction and / or were willing to coproduce, a survey was carried out with 269 families of students from different administrative regions of the Federal District, analyzed by linear and logistics regression. Has been identified a broad legislative apparatus that: encourages coproduction by providing benefits to family members who support students in the educational process, such as the Bolsa Família Program; defining punishments for those who do not, such as a loss of guardianship; end also ensuring participation environments, such as school councils and parents' meetings. The schools encourage coproduction by using government policies and bringing family members closer to the school, such as events, but using legal devices in cases of families' negligence, especially in relation to the coproduction of basic support, a form of family participation unidentified in studies conducted in European countries. The survey conducted with students' families has shown that pedagogical coproduction is the most frequent, followed by social coproduction, and that there is no significant difference between the frequency of individual and collective coproduction. Individual coproduction is influenced mainly by the level of education of the family member and by domestic habits, especially the habit of reading and going to theater, indicating that public policies to encourage higher education may positively effect on the coproduction of elementary education, especially in the economic and pedagogical. This study adds the understanding of how coproduction of public services occurs in developing countries, and how the user profile of service impacts the coproduction of public education. The results provide a basis on which public policies to encourage coproduction can be formulated and implemented.
\end{abstract}

Keywords: public services coproduction; citizen engagement; public sector; government. 


\section{LISTA DE ABREVIAÇÕES}

ECA

Estatuto da Criança e Do Adolescente

LDB

Lei de Diretrizes e Bases da Educação 


\section{LISTA DE ILUSTRAÇÕES}

Figura 1: Framework de incentivo à coprodução da educação pública ...................................39

Figura 2: Comparação da explicação dos resultados escolares em diferentes estudos em pontos percentuais - adaptado de Christophe et al. (2015) ...........................................28 


\section{LISTA DE QUADROS}

Quadro 1 - Divisão do Esforço entre Profissionais e Usuários, adaptado de Bovaird (2007).. 16

Quadro 2 - Diferenciação entre coprodução e cocriação de serviços - Adaptado de Chathoth et

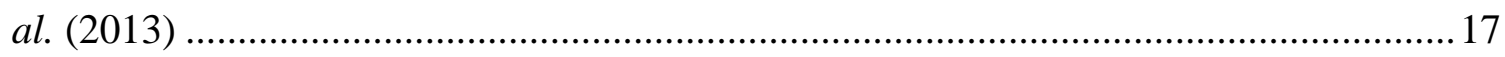

Quadro 3 - Principais conceitos de coprodução …................................................................ 17

Quadro 4 - Tipos de contribuição da educação segundo Pestoff (2006) ..................................22

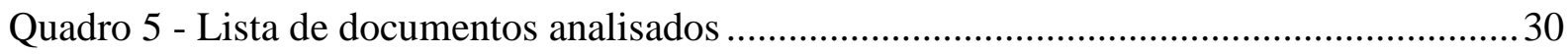

Quadro 6 - Quantidade de escolas por Coordenação Regional de Ensino do GDF (fonte:

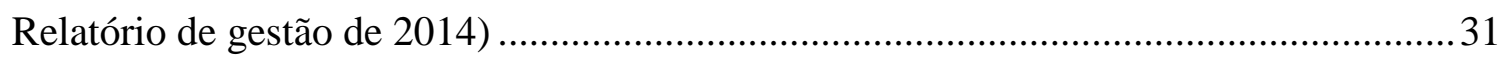

Quadro 7 - Perfil de gestores escolares entrevistados ......................................................... 32

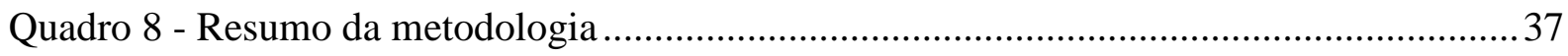

Quadro 9 - Registro da inclusão e confirmação de categorias de mecanismos formais de

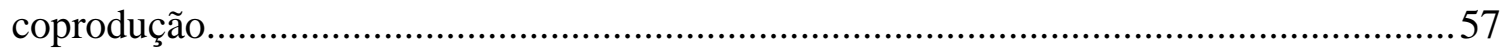

Quadro 10 - Relação de categorias e exemplos observados de mecanismos formais de coprodução. 59

Quadro 11 - Registro da inclusão e confirmação de categorias de estratégias de incentivo à coprodução. 64

Quadro 12 - Relação de categorias e exemplos observados de estratégias de incentivo à de coprodução. 65

Quadro 13 - Registro da inclusão e confirmação de categorias de formas de coprodução da educação pública..

Quadro 14 - Relação de categorias e exemplos observados de formas de coprodução da educação pública 


\section{LISTA DE TABELA}

Tabela 1 - Questão: A quais das atividades a seguir você se dedica voluntariamente para

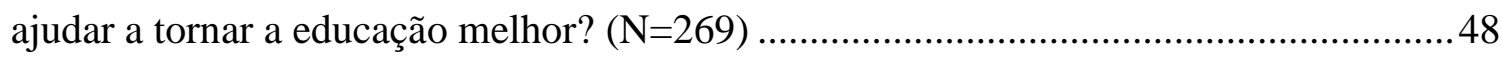

Tabela 2 - Caraterização da coprodução entre a família e a escola $(\mathrm{N}=269)$.........................48

Tabela 3 - Caraterização e comparação da coprodução coletiva e individual entre a família e a

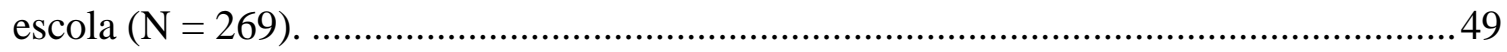

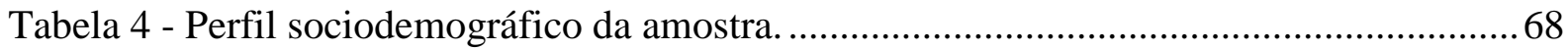

Tabela 5 - Caraterização da amostra quanto aos hábitos familiares......................................69

Tabela 6 - Escolaridade dos familiares vs. expectativa quanto à escolaridade dos alunos. .....71

Tabela 7 - Modelos de regressão logística com a coprodução social e a coprodução política

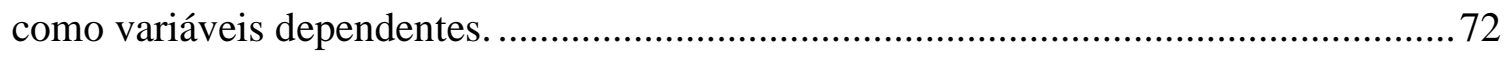

Tabela 8 - Modelos de regressão logística com cada um dos 2 itens da coprodução pedagógica

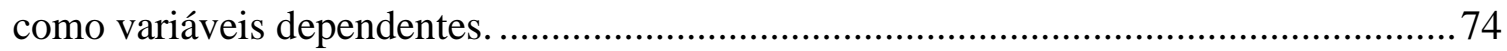

Tabela 9 - Modelos de regressão logística com cada um dos 2 itens da coprodução econômica

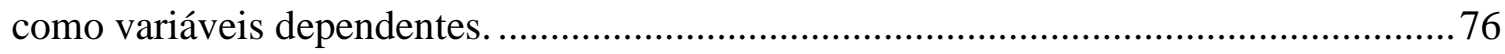

Tabela 10 - Modelos de regressão linear com a coprodução coletiva e a coprodução individual como variáveis dependentes. 


\section{SUMÁRIO}

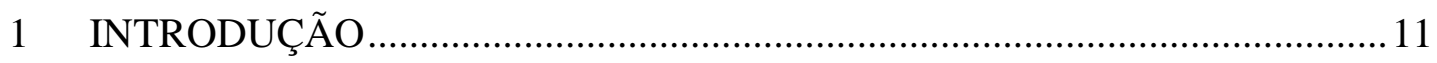

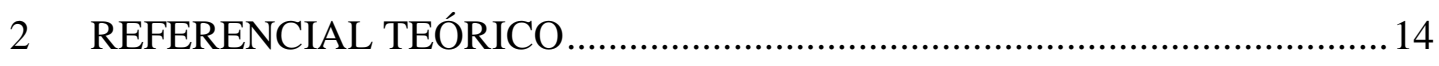

2.1 Ações de incentivo à coprodução promovidas pelo prestador de serviço ...........18

2.2 Relação entre a coprodução e o perfil do usuário.............................................20

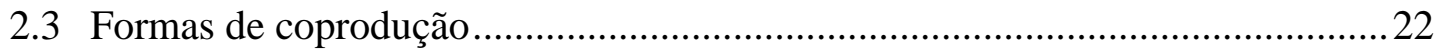

2.4 Framework demonstrativo do incentivo à coprodução na educação pública......38

3 MÉTODOS E TÉCNICAS DA PESQUISA ....................................................26

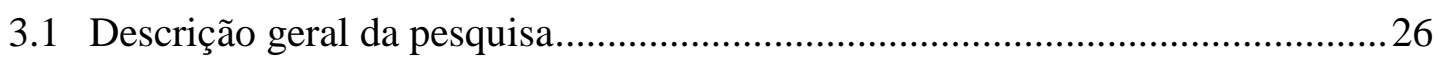

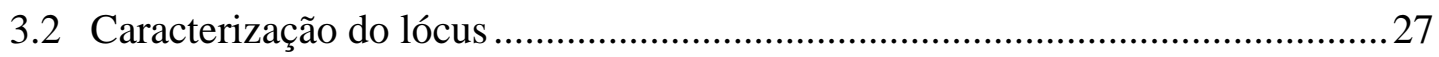

3.3 Procedimentos de coleta, população e amostra ..................................................29

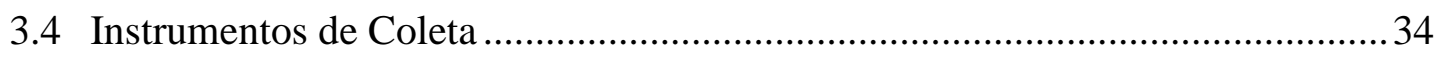

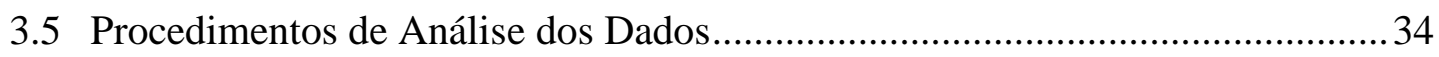

3.6 Quadro resumo da métodos e técnicas de pesquisa........................................37

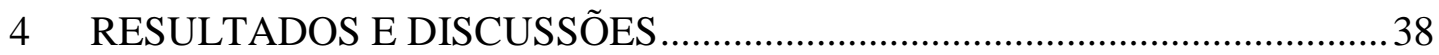

4.1 Políticas de incentivo à colaboração de familiares pelos governos federal e

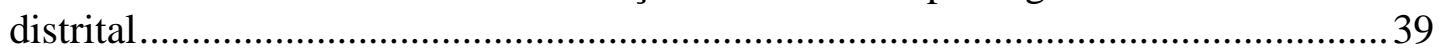

4.2 Ações das escola de Incentivo à coprodução da educação .................................56

4.3 Formas de coprodução da oferta do ensino fundamental por familiares de alunos 39

4.4 Influência do perfil do usuário nas formas de coprodução .67

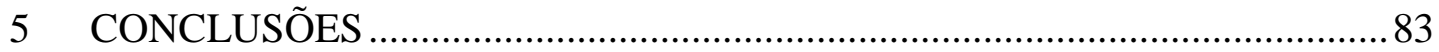

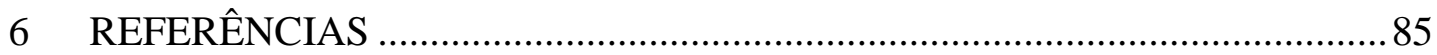

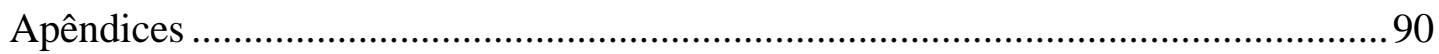

Apêndice A - TCLE e Roteiro da Entrevista ............................................................90

Termo de Consentimento Livre e Esclarecido - Entrevista ..................................... 90 
Roteiro de entrevista com gestores de escolas de ensino fundamental do Distrito

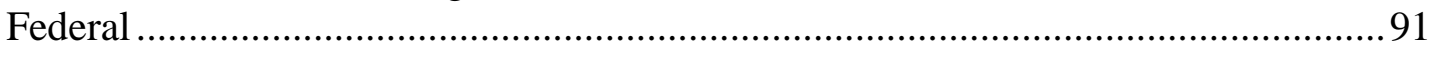

Apêndice B - Questionário de entendimento do perfil e formas de coprodução da educação para aplicação junto a familiares ..............................................................99

Termo de Consentimento Livre e Esclarecido - TCLE - Questionário ......................93 


\title{
1 INTRODUÇÃO
}

\author{
"No market can survive without extensive public goods provided by \\ governmental agencies. No government can be efficient and equitable \\ without considerable input from citizens." \\ Elionor Ostrom
}

A interação entre clientes e fornecedores de serviços é amplamente discutida por diversas linhas de pesquisa, como marketing e inovação, e também na administração pública, quando o cliente em questão é o cidadão. Uma importante forma de interação é aquela onde o esforço do usuário contribui com a prestação do serviço, para a qual Ostrom e Ostrom (1977) cunharam o termo coprodução.

A coprodução vem sendo estudada desde as décadas de 70 e 80 focando principalmente a exploração do conceito, nível de importância do usuário, ao momento de participação (concepção ou prestação do serviço), tipo de colaboração (individual ou coletiva), entre outros. Para tanto foram investigados casos de serviços prestados nos quais a participação dos usuários era essencial (Ostrom \& Ostrom, 1977; Withaker ,1981; Parks, Baker, Kiser, Oakerson, Ostrom, Ostrom, Percy, Vandivort, Whitaker \& Wilson, 1981; Sharp, 1980; Rosentraub \& Sharp, 1982). A partir dos anos 90 foram realizadas pesquisas com objetivo de aprofundar o entendimento desse fenômeno, sendo alcançados resultados quanto às motivações para a coprodução, as formas pelas quais ela ocorre, bem como seus efeitos para a qualidade dos serviços e satisfação dos clientes. (Davis \& Ostrom, 1991, Bovaird, 2007, Bovaird \& Loeffler, 2012; Alford, 1998, 2002, 2002B, 2009; Edvardsson, Gustafsson, Kristensson, \& Witell, 2010; Pestoff, 2012, 2014; Osborne \& Strokosch, 2013). Ostrom (1996) iniciou a exploração das políticas promovidas pelas prestadoras para motivar o engajamento dos usuários na produção de serviços. Já a produção acadêmica empírica com fins explicativos se iniciou no fim da primeira década dos anos 2000, com um estudo de ampla amostra distribuída em cinco países europeus (Alemanha, Reino Unido, França, República Tcheca e Dinamarca), abordando os serviços de saúde, segurança pública e cuidado com o ambiente, conduzido Loeffler, Parrado, Bovaird e Van Ryzin (2008) com o objetivo de 
entender as circunstâncias em que a coprodução ocorre. Com o mesmo método Alford e Yates (2015) buscaram entender o comportamento da coprodução na Austrália.

A literatura da coprodução de serviços públicos ainda necessita de desenvolvimento em diversos caminhos, como um maior entendimento das formas de colaboração, das políticas de incentivo, da sua efetividade e de como elas se relacionam com o perfil do usuário e do serviço (Osborne \& Strokosch, 2013; Pestoff, 2014; Alford, 2015). São levantadas assim questões como: por quais formas a coprodução ocorre em países de nível de desenvolvimento brasileiro? Dado que a coprodução ocorre, como o governo pode incentivá-la?

Nesse sentido, o objetivo geral deste trabalho é identificar como o governo e escolas têm fomentado o ensino fundamental público por meio do incentivo à coprodução de familiares de alunos, e como o perfil destes familiares influencia as formas de coprodução.

Para alcançar o objetivo geral deste trabalho, foram definidos os objetivos específicos:

a) Elaborar um framework de incentivos à coprodução de serviços públicos;

b) Identificar formas pelas quais a coprodução de familiares ocorre na oferta do ensino fundamental;

c) Identificar políticas de incentivo à coprodução dos familiares no ensino fundamental promovidas pelos governos federal e do distrito federal;

d) Identificar as ações de incentivo à coprodução do ensino fundamental promovidas pelas escolas;

e) Verificar a influência do perfil de familiares de alunos nas formas de coprodução.

As formas de coprodução e as políticas de incentivo promovidas pela prestadora do serviço demandam uma investigação empírica abrangendo diferentes países, mas com um mesmo serviço (Pestoff, 2006) e de um entendimento que abranja esse fenômeno junto a usuários de baixa renda, pois, como defendido por Ostrom (1996), estes cidadãos tendem a ser os maiores beneficiários da coprodução. Os anos iniciais do ensino fundamental se mostram uma oportunidade temporal condizente com os propósitos deste estudo, por ter na participação 
de familiares de alunos um fator essencial para a produção do serviço, uma vez que os alunos de até os onze anos possuem alta dependência de suporte da família.

Especialmente no Brasil, onde a educação é considerada um direito do cidadão conforme a Constituição Federal, e um dos desafios atuais é a universalização do ensino, conforme o Plano Nacional de Educação, o entendimento da coprodução por familiares da oferta do ensino fundamental público se mostra essencial, uma vez que parcela relevante tem perfil socioeconômico diferente de famílias já estudadas por Pestoff (2006, 2012), que focalizou países ricos, e Ostrom (1996), que focalizou países mais pobres.

A partir de um maior entendimento das formas de incentivo à coprodução de familiares espera-se contribuir para a gestão do ensino fundamental ao subsidiar o trabalho dos diretores escolares e formuladores de políticas educacionais. 


\section{REFERENCIAL TEÓRICO}

Ostrom, Parks, Whitaker e Percy (1978) introduzem a participação do cliente na produção do serviço como uma alternativa para lidar com a dificuldade de satisfazer usuários de serviços coletivos. Os autores utilizam o termo coprodução, que representa os casos em que o esforço inteligente e motivado do usuário do serviço é essencial, de forma que sem ele o serviço pode perder seu valor ou se tornar um produto indiferente.

Parks (1981) utiliza a conhecida história de Robinson Crusoé para elucidar o conceito de coprodução. Crusoé consumia apenas o que conseguia produzir ou coletar. Ao contrário da perspectiva de consumo na vida em sociedade, onde os indivíduos tendem a se especializar, de forma que em sua maioria trocam seus produtos por dinheiro para no futuro adquirir diferentes produtos. Esses indivíduos são chamados por Parks (1981) de Produtores Regulares. Todavia, às vezes os indivíduos vão trabalhar fora do seu papel de produção regular para contribuir com produtos ou serviços que irão consumir. Nesses casos, atuam como Produtores Consumidores. O autor conclui que em vários casos a produção do consumidor é essencial para o resultado do trabalho, sendo essa a característica da maioria dos serviços públicos. O autor apresenta, dessa forma, uma das primeiras definições de coprodução, como o trabalho no qual o indivíduo servido é inevitavelmente parte do processo de produção, sendo o resultado do trabalho fruto de esforço conjunto.

No setor público, Whitaker (1980) apresenta, em um contexto onde a participação era comumente vista como tentativa de influenciar a formulação de políticas públicas, a ideia de que cidadãos de fato exercem importante influência nas políticas por meio da participação na sua execução. Sharp (1980) propõe um modelo de coprodução, baseado no conceito de Whitaker (1980), em que as competências do cidadão devem ser desenvolvidas e aproveitadas para uma boa prestação de serviços públicos. Este modelo viria como uma alternativa ao tradicional, no qual o governo tem o papel de executar sozinho o serviço, ao passo que o cidadão tem o papel de demandar e cobrar sua boa execução.

Já Brudney e England (1983) avançaram no conceito ao apresentar uma tipologia de coprodução levando em consideração o nível de interação entre os envolvidos (individual, 
com grupos e coletiva). A coprodução individual representa o esforço do usuário do serviço empreendido com objetivo de gerar valor aproveitado pelo próprio coprodutor. Com grupos, é apresentado pelos autores, como a coprodução que envolve várias pessoas, pode necessitar de coordenação formal, e tem um impacto em um grupo de usuários do serviço. A coletiva, por sua vez, envolve benefícios a todos os possíveis usuários do serviço, como, por exemplo, um mutirão para limpeza de um parque.

O grau de importância da participação do consumidor na prestação de serviço também foi utilizado como critério de tipificação da coprodução. Bitner, Faranda, Hubbert e Zeithaml (1997) segmentaram os serviços em três categorias a partir deste critério: na primeira o consumidor é apenas um recurso produtivo; na segunda, seu esforço é importante para a qualidade, satisfação e valor do serviço; e na terceira, o papel do consumidor poderia potencialmente substituir o papel da organização prestadora.

Já sob a lente da produção acadêmica focada em serviços, Gallouj e Weinstein (1997) discutem a participação do cliente a partir da inclusão da influência das suas características no modelo de previsão da qualidade do serviço. Os autores apontam que a participação do consumidor no desenvolvimento e produção de um serviço seria um dos principais fatores determinantes do seu resultado. Esse modelo foi amplamente aceito e desenvolvido, como por Windrum e Garcia-Goñi (2008), que incluíram características de diversos agentes como preditoras das características do serviço, tais como: competências de produção, competências de tratamento do usuário e preferências do provedor do serviço, características do serviço, competências e preferências dos responsáveis por políticas públicas e dos usuários.

Já Edvardsson et al. (2010) diferenciam os conceitos de produção e coprodução, apresentando o primeiro como o trabalho totalmente realizado pela empresa e seus empregados, sem a participação dos clientes, e o segundo como a interação e participação do cliente na produção do serviço. Os autores inserem ainda um terceiro nível de participação do consumidor, na qual a produção é totalmente realizada pelo cliente, sem a participação da organização ou de seus colaboradores, e a nomeia de Produção do Consumidor. Dessa forma, o nível de participação do cliente estaria nos extremos, Produção e Produção do Consumidor, e um nível intermediário que seria a coprodução.

Bovaird (2007) contribui com a organização do conceito de coprodução ao propor uma matriz na qual os eixos representam as atividades de planejar e prestar o serviço. Cada atividade é dividida em três categorias, a primeira representa profissionais como responsáveis, 
a segunda profissionais e usuários como responsáveis e a terceira apenas usuários como responsáveis, como explicitado no Quadro 1 - Divisão do Esforço entre Profissionais e Usuários, adaptado de Bovaird (2007). A matriz mostra que, sem o envolvimento do usuário na prestação do serviço, o nível de interação pode aumentar até a participação conjunta no planejamento ou concepção do serviço, que segundo o autor caracterizaria uma cocriação. $\mathrm{O}$ autor titula de Coprodução completa pelo usuário/profissional a situação na qual tanto o profissional quanto o usuário participam tanto do planejamento quanto da prestação do serviço. No extremo do envolvimento do usuário no serviço, o autor apresenta as comunidades auto organizadas, nas quais tanto o planejamento quanto a prestação são de inteira responsabilidade do consumidor do serviço.

Quadro 1 - Divisão do Esforço entre Profissionais e Usuários, adaptado de Bovaird (2007)

\begin{tabular}{|c|c|c|c|}
\hline & $\begin{array}{l}\text { PROFISSIONAIS } \\
\text { COMO } \\
\text { PLANEJADORES } \\
\text { ÚNICOS DO } \\
\text { SERVIÇO }\end{array}$ & $\begin{array}{l}\text { USUÁRIO DO SERVIÇO E / } \\
\text { OU COMUNIDADE COMO } \\
\text { COPLANEJADORES }\end{array}$ & $\begin{array}{l}\text { NENHUMA } \\
\text { ENTRADA DE } \\
\text { PROFISSIONAIS NO } \\
\text { PLANEJAMENTO } \\
\text { DE SERVIÇOS }\end{array}$ \\
\hline $\begin{array}{l}\text { Profissionais como } \\
\text { prestadores únicos do } \\
\text { serviço }\end{array}$ & $\begin{array}{l}\text { Prestação de serviço } \\
\text { profissional } \\
\text { tradicional }\end{array}$ & $\begin{array}{l}\text { Prestação de serviço profissional } \\
\text { tradicional com usuários e } \\
\text { comunidades envolvidas no } \\
\text { planeamento e concepção (por } \\
\text { exemplo, o orçamento participativo) }\end{array}$ & $\mathrm{N} / \mathrm{D}$ \\
\hline $\begin{array}{l}\text { Profissionais e } \\
\text { usuários/ } \\
\text { comunidades como } \\
\text { coprestadores do } \\
\text { serviço }\end{array}$ & $\begin{array}{l}\text { Usuário coprestador } \\
\text { dos serviços criados } \\
\text { por profissionais }\end{array}$ & $\begin{array}{l}\text { Coprodução completa pelo usuário/ } \\
\text { profissional }\end{array}$ & $\begin{array}{l}\text { Usuário / comunidade } \\
\text { coprestação de serviços } \\
\text { com profissionais, com } \\
\text { pouco planejamento formal } \\
\text { ou projeto }\end{array}$ \\
\hline $\begin{array}{l}\text { Usuários/ } \\
\text { comunidades como } \\
\text { distribuidores } \\
\text { exclusivos }\end{array}$ & $\begin{array}{l}\text { Entrega usuário / } \\
\text { comunidade de } \\
\text { serviços } \\
\text { profissionalmente } \\
\text { planejados }\end{array}$ & $\begin{array}{l}\text { Entrega usuário / comunidade de } \\
\text { serviços coplanejados ou cocriados }\end{array}$ & $\begin{array}{l}\text { Prestação tradicional } \\
\text { comunidade auto- } \\
\text { organizada }\end{array}$ \\
\hline
\end{tabular}

Com o propósito de entender as possibilidades de interação com o cliente, Alford (2015) coloca a visão de os serviços serem necessariamente coproduzidos sob uma perspectiva crítica, defendendo que a coprodução é variável. A extensão, segundo o autor, varia de opcional a essencial, à medida que a proposta de valor e o serviço variam. Assim, existem diversos arranjos de interação com o cliente, sendo a coprodução uma delas, assim como a cocriação. Chathoth, Altinay, Harrington, Okumus e Chan (2013) diferenciam os conceitos de coprodução e cocriação, defendendo que as firmas não precisam se posicionar em apenas uma perspectiva, sendo possível um meio termo, o que dá sentido à sua analogia de uma linha contínua cujos extremos vão da coprodução, até a cocriação de serviços, e a estratégia de interação com o cliente pode se posicionar em qualquer ponto dessa linha. Para os autores, a coprodução se diferencia da cocriação em termos de criação de valor, papel do 
consumidor, participação e expectativas do consumidor, foco, inovação e comunicação, como apresentado no Quadro 2 - Diferenciação entre coprodução e cocriação de serviços Adaptado de Chathoth et al. (2013).

Quadro 2 - Diferenciação entre coprodução e cocriação de serviços - Adaptado de Chathoth et al. (2013)

\begin{tabular}{lll}
\hline & COPRODUÇÃO & COCRIAÇÃO \\
\hline 1) Criação de valor, & O aumento da qualidade do serviço & Serviço customizado \\
\hline 2) Papel do consumidor & Passivo & Ativo \\
\hline $\begin{array}{l}\text { 3) Participação e expectativa } \\
\text { do consumidor }\end{array}$ & $\begin{array}{l}\text { Atuando no fim da cadeia de valor } \\
\text { adaptando o serviço às suas necessidades. }\end{array}$ & $\begin{array}{l}\text { Ao longo de toda a cadeia de valor } \\
\text { como um ator chave }\end{array}$ \\
\hline 4) Foco & Processo da própria firma & Cliente e sua experiência \\
\hline 5) Inovação & Firma responsável por gerar inovações & Tornando-o central para a inovação \\
& & \\
\hline 6) Comunicação & A partir da coleta da percepção dos & A partir de um diálogo constante \\
& consumidores & \\
\hline
\end{tabular}

Já Osborne e Strokosch (2013), utilizando o conceito de coprodução como referente apenas à participação na execução e entrega do serviço, cruzaram níveis de participação (individual e interorganizacional) com as diferentes etapas da prestação de serviços (planejamento e entrega) com foco no setor público como prestador. O resultado foi uma classificação na qual o planejamento pode ser apresentado como individual (coprodução participante ou ampliada) ou organizacional (cogovernança), e a entrega pode ser individual (coprodução de consumo) ou organizacional (cogestão). O Quadro 3 - Principais conceitos de coproduçãoresume os conceitos de coprodução de serviços mais utilizados.

Quadro 3 - Principais conceitos de coprodução

\begin{tabular}{ll}
\hline $\begin{array}{l}\text { REFERENCIA (autor, } \\
\text { ano) }\end{array}$ & CONCEITO DE COPRODUÇÃO \\
\hline Etgar 2008 & Participação do consumidor no desempenho das etapas da prestação do serviço. \\
\hline $\begin{array}{l}\text { Ostrom, 1996; Osbourne e } \\
\text { Strokosch, 2013; Pestoff } \\
(\mathbf{2 0 0 6 , 2 0 1 2 , 2 0 1 4 )}\end{array}$ & $\begin{array}{l}\text { Coprodução implica em cidadão podendo exercer um papel ativo na produção } \\
\text { serviços públicos. }\end{array}$ \\
\hline Bovaird, 2007 & A coprodução do usuário ou da comunidade e o provimento de um serviço a \\
& partir de uma relação regular e de longo prazo entre profissionais provedores \\
& do serviço e usuários ou outros membros da comunidade, onde todas as partes \\
& contribuem substancialmente. \\
\hline Parks, 1981 & $\begin{array}{l}\text { Trabalho no qual o indivíduo servido é inevitavelmente parte do processo de } \\
\text { produção, sendo o resultado do trabalho fruto de esforço conjunto }\end{array}$ \\
\hline Edvardsson et al., 2010 & Coprodução é a prestação do serviço com a interação entre o cliente e o \\
& profissional prestador. \\
\hline Brudney e England, 1983 & $\begin{array}{l}\text { A coprodução ocorre quando a coordenação do trabalho da prestadora de } \\
\text { serviço e do usurário não é regida apenas por feedbacks, mas sim ocorrem } \\
\text { quase simultaneamente. }\end{array}$ \\
\hline
\end{tabular}


Verschuere, Brandsen e Pestoff (2012) sistematizam a agenda de pesquisa recente sobre coprodução em três grupos de resultados, sendo o primeiro o entendimento das circunstâncias nas quais as pessoas coproduzem; o segundo, como a coprodução funciona e quais as variáveis relacionadas à sua efetividade; e, por último, o entendimento do efeito da coprodução na qualidade do serviço e satisfação do consumidor. Os autores apontam a necessidade de pesquisas empíricas e comparativas, que permitam testar se a coprodução, por exemplo, gera capital social, novas relações e comportamento cooperativo, maior qualidade nos serviços públicos, redução de custos e maiores benefícios para a prestadora e usuários. É defendida também a necessidade da utilização de uma gama metodológica mais diversa, quantitativa e comparada.

\subsection{Ações de incentivo à coprodução promovidas pelo prestador de serviço}

Ostrom (1996) estudou dois casos de coprodução procurando entender, entre outros fatores relacionados, as ações das organizações governamentais relacionadas ao fomento à coprodução de serviços públicos. No primeiro, a autora descreveu a evolução da infraestrutura de saneamento básico no Brasil ao longo da década de 1980 e 1990 a partir do compartilhamento de responsabilidade e investimento entre o governo e os cidadãos usuários do serviço, identificando que os agentes governamentais convidaram os cidadãos a participar desde o início do planejamento do serviço, ou seja, na definição de como seria o sistema de saneamento, a partir da promoção de diversas reuniões de vizinhança. Nesta etapa eram tomadas decisões que impactavam o custo, local de implantação do sistema e a forma de manutenção, essa última, sob responsabilidade do dono da residência. A autora cita a importância nesse contexto do amplo provimento de informação aos cidadãos, bem como da ajuda na mediação do diálogo que levou às tomadas de decisão. Posteriormente, os agentes governamentais ficavam responsáveis por monitorar as linhas de transmissão de água e esgoto e acionar os cidadãos em caso de necessidade de manutenção.

Outro caso citado por Ostrom (1996) é a educação básica da Nigéria. O governo nigeriano ao passar por diversos momentos intercalados de crescimento e de crise econômica, bem como instabilidade política, mudou constantemente as políticas públicas de educação, e com isso viu a participação das famílias de alunos perder força. Em alguns momentos o 
governo centralizou o serviço (governo militar em 1976 e em 1988), em outros dividiu a responsabilidade, devido aos choques do petróleo no início da década de 1980 e no início da década de 1990, quando a responsabilidade de financiamento passou totalmente para os governos locais. Houve anos em que livros didáticos eram repassados às escolas e, sem aviso, houve anos em que não havia o repasse. Todas essas mudanças não levaram em consideração a opinião de familiares e professores, o que levou a autora a concluir que a coprodução deste serviço foi amplamente prejudicada por essa postura mais autoritária do governo, que não tomava as decisões junto a quem de fato fazia a educação. É citado o caso de uma escola com participação relevante dos pais na educação, onde voluntariamente refizeram o sistema de saneamento e de outra com alta frequência de alunos, na qual a associação de pais e professores estava ativa desde 1970 .

Alford (2009), ao tratar das relações entre o setor público e o cidadão na coprodução do serviço, identificou uma categoria de consumidores que seriam obrigados a coproduzir. No caso, o usuário do serviço não necessariamente receberia um valor em serviço ou mercadorias, mas sim estaria suscetível a sofrer ônus do órgão público responsável pela prestação do serviço.

Thaler e Sunstein (2009) discutem como os órgãos públicos podem levar os cidadãos a agir de forma a gerar benefícios públicos a partir do entendimento das limitações nas tomadas de decisão dos mesmos. Os autores indicam que o setor público pode lançar mão de "nudges", que pode ser traduzido como "empurrãozinho", mas que melhor se traduz com "incentivos sutis". Eles levantam cinco formas de incentivar o cidadão à decisão preferida pelo governo: definição desta decisão como padrão, ou seja, o cidadão automaticamente escolhe essa opção, mas pode optar por alguma alternativa; identificação dos possíveis erros na tomada de decisão e estabelecimento de mecanismos que informem e eduquem rapidamente o usuário do serviço para prevenir erros futuros; padronização de feedbacks tempestivos sobre as consequências das escolhas do cidadão; atenção aos fatores levados em consideração pelos cidadãos na decisão e indicação de fatores que se mostram favoráveis à decisão preferida do governo; e por último, criação de contextos de debate entre grupos de cidadão relacionados na decisão, uma vez que as pessoas tendem a considerar opiniões dos pares. Apesar de não citar casos da educação básica, Thaler e Sunstein (2009) apresentam que esses mecanismos de incentivo seriam aplicáveis a quaisquer contextos. John, Smith e Stoker (2009) trazem uma visão alternativa à de Thaler e Sunstein (2009). Os autores levantam que os incentivos dados aos usuários dos serviços em tomar determinadas decisões deveriam se 
embasar na forma fundamentada no debate com pares, uma vez que esta não toma o que o governo acha que é melhor para o cidadão como verdade, mas sim, da flexibilidade para que qualquer decisão profícua para o serviço público como um todo seja tomada.

Buscando entender incentivos à coprodução, Bovaird, Van Ryzin, Loeffler e Parrado (2015) estudaram fatores relacionados à coprodução a partir de um survey junto a usuários de serviços públicos - segurança pública, cuidado com o meio ambiente, saúde e bem-estar social - na Inglaterra e no País de Gales. Para isto, proviam a alguns grupos da amostra informações sobre a coprodução: exemplos de serviço onde o esforço do cidadão era relevante para a qualidade, ou falavam quanto esforço outros cidadãos despendiam na coprodução daquele serviço. A pesquisa mostrou que o provimento das informações aumentou a propensão de coproduzir no combate ao crime em dois terços das cidades onde o serviço foi pesquisado, em especial quando se tratava de colaboração coletiva, porém o efeito não foi considerado forte pelos pesquisadores.

\subsection{Relação entre a coprodução e o perfil do usuário}

A produção acadêmica referente à motivação do usuário de serviços para coproduzir está desenvolvida a ponto de já estarem testadas as variáveis-chave, como gênero, idade, percepção de eficácia do cidadão e percepção de eficácia do governo, e seus efeitos na propensão à coprodução, como, por exemplo, as pesquisas de Pestoff (2012), Bovaird, Stoker, Jones, Loeffler, e Rocancio (2015) e de Alford e Yates (2015).

A partir de estudo de um caso de êxito da coprodução e de outro caso com poucos resultados, Ostrom (1996) apresentou dois desafios para o engajamento dos cidadãos:1) a organização dos cidadãos e o cumprimento das promessas coletivamente; 2) a capacidade de trabalho de equipe por parte do governo, e a coordenação efetiva entre cidadão e a agência governamental. Ao comparar a participação de familiares em escolas de vilas nigerianas, a autora concluiu que a coprodução é desencorajada quando o governo é centralizador, ao passo que uma vez que o cidadão tem um sentimento de dono quanto ao serviço, tende a colaborar mais. A pesquisa aponta o papel essencial da coprodução para a redução da corrupção, uma vez que reduz o capital oriundo do governo, aumentando o capital vindo do cidadão 
beneficiário do serviço. Ao contrário do sugerido por Rosentraub e Sharp (1981), que apontam a maior instrução das classes mais ricas como fator positivo à coprodução, Ostrom (1996) assinala que, a despeito da menor instrução das classes mais carentes da sociedade, estas são as maiores beneficiárias da coprodução, uma vez que os serviços públicos tradicionais, na prática, tendem a atender melhor as classes mais favorecidas.

Pestoff (2006) estudou a coprodução no serviço de pré-escola a partir de uma pesquisa em oito países europeus: Bélgica, Bulgária, Inglaterra, França, Alemanha, Itália, Espanha e Suíça, concluindo que o engajamento de familiares na escola ainda se mostrava como um desafio para as organizações públicas e privadas, assim como a abertura dos profissionais a coproduzir. Esses desafios teriam sido superados apenas por organizações do terceiro setor, como cooperativas de pais, onde a coprodução exerce um papel central. Esse resultado foi reafirmado por Pestoff (2012), que incluiu como lócus de pesquisa a educação infantil na Suíça.

Alves, Nogueira, Marques e Freitas (2013), ao investigarem a participação da família no provimento de ensino fundamental, estudaram a relação do aprendizado com as variáveis: 1) Indicador de Nível Sócio Econômico das Escolas (INSE); 2) Tipo de escola (municipal, estadual, federal ou privada); 3) Conhecimento do sistema de ensino; 4) Posse de bens culturais; 5) Práticas cotidianas de escrita; e 6) Ordem racional doméstica (costume da família de se planejar e gerir, evidenciado pelo uso de lista de compras, caderno de receitas, lista de coisas pra fazer, entre outros); (7) práticas familiares de leitura; (8) ambição escolar (expectativa que a família tem de aprendizado do aluno); e (9) interação pais e filhos. O estudo foi realizado a partir de uma partir de uma pesquisa que coletou entre os anos de 2005 e 2008 a proficiência dos alunos em língua portuguesa e matemática e as variáveis supracitadas. Após remover o quintil superior considerando o contexto socioeconômico para diminuir o efeito desta variável, a amostra considerada foi de 299 famílias. A partir da análise dos dados foi identificada correlação significativa entre as seis variáveis e o aprendizado.

Bovaird et al. (2015) investigaram o comportamento de cidadãos no contexto de coprodução a partir de um estudo em cinco países europeus, a saber: Alemanha, Reino Unido, França, República Tcheca e Dinamarca, e identificaram fatores-chave relacionados à propensão de cidadãos a colaborar com serviços públicos, a saber: variáveis sociodemográficas (idade, gênero, nível educacional, profissão, residência urbana ou rural); percepção de eficácia do usuário (o quanto o cidadão acredita que seu trabalho pode 
contribuir com a qualidade do serviço); e a percepção do cidadão quanto à eficácia do governo. Foi ressaltada a maior propensão à coprodução em contextos nos quais o esforço do cidadão é independente de terceiros, ou seja, quando a colaboração é individual. Os autores identificaram também o desejo dos cidadãos em colaborar mais com os serviços públicos, porém não foi apresentado o fator que os motivaria a fazê-lo.

\subsection{Formas de coprodução}

As diferentes formas de coprodução de serviços vêm sendo estudadas desde a gênese do conceito. Começando pela organização do usuário do serviço, que pode ser um ator individual ou trabalhar em grupos informais ou mesmo organizações, como apresentado por Brudney e England (1983).

Outra contribuição às formas de coprodução foi feita por Ostrom (1996), que ao estudar a coprodução da educação primária identificou vários projetos empreendidos por familiares para melhorar a estrutura física e condições sanitárias das escolas. Ao investigar a educação infantil na Europa, Pestoff (2006) identificou quatro tipos de contribuição de familiares para a educação de alunos, tais como: econômicas, políticas, pedagógicas e sociais, cada um destes apresentando diferentes maneiras pelas quais se dava a coprodução, cujos exemplos são apresentados no Quadro 4 - Tipos de contribuição da educação segundo Pestoff (2006).

Quadro 4 - Tipos de contribuição da educação segundo Pestoff (2006)

\begin{tabular}{ll}
\hline Tipo de Contribuição & Exemplos de Coprodução \\
\hline Econômica & $\begin{array}{l}\text { Tempo em reuniões da escola e atividades de suporte a reformas ou eventos } \\
\text { pedagógicos, dinheiro referente a taxas, compra de materiais e doações. }\end{array}$ \\
\hline Política & $\begin{array}{l}\text { Participação nas decisões dos conselhos escolares, conselhos municipais de } \\
\text { educação, associação de pais e professores. }\end{array}$ \\
\hline Pedagógico & Interação com o aluno no dia-a-dia, acompanhamento nas tarefas de casa. \\
\hline Social & Promoção e participação em eventos culturais da escola. \\
\hline
\end{tabular}

Na pesquisa de Alves et al. (2013) sobre a influência de familiares no desempenho do aluno, além das variáveis independentes referentes ao contexto, citadas no item 2.2. - 1) Indicador de Nível Sócio Econômico das Escolas (INSE); 2) Tipo de escola (municipal, estadual, federal ou privada); 3) Conhecimento do sistema de ensino; 4) Posse de bens culturais; 5) Práticas cotidianas de escrita; e 6) Ordem racional doméstica (costume da família de se planejar e gerir, evidenciado pelo uso de lista de compras, caderno de receitas, lista de 
coisas pra fazer, entre outros) - foram consideradas três variáveis independentes referentes à forma de coprodução da educação: (7) práticas familiares de leitura; (8) ambição escolar (expectativa que a família tem de aprendizado do aluno); e (9) interação pais e filhos. O estudo confirmou a influência de todos os aspectos listados no desempenho do aluno, assim como a alta correlação entre eles, além de identificar a importância das desigualdades sociais na contribuição da família para o aprendizado. O modelo testado com as práticas familiares de leitura (além do nível sócio econômico) apresentou um $\mathrm{R}^{2}$ ajustado de $36 \%$. O modelo testado com ambição escolar (além do nível sócio econômico) apresentou um $\mathrm{R}^{2}$ ajustado de $36 \%$. $\mathrm{O}$ modelo testado com a interação entre pais e filhos (além do nível sócio econômico) apresentou um $\mathrm{R}^{2}$ ajustado de $35 \%$. Chubb e Moe (1990) também defendem que os lares das crianças que frequentam as melhores escolas tendem a ter familiares que encorajam os alunos a aprender, auxiliando intensamente nas lições de casa e mantendo maior expectativa quanto ao aprendizado da criança.

Ostrom (2009) apresentou as seguintes variáveis relacionadas ao sucesso da coprodução:

a) Tamanho do grupo envolvido: a coprodução pode ser individual, em grupo, social.

b) Possibilidade de escassez dos benefícios: aqueles cuja exploração por um indivíduo pode gerar o risco de escassez do serviço, como água, pesca etc.

c) Heterogeneidade do serviço conforme o consumidor, ou seja, quando indivíduos ou grupos participam em uma mesma intensidade, geram resultados diferentes.

d) Comunicação presencial.

e) Informações sobre ações passadas também são relevantes, como na interação entre vizinhos que moram próximos há muito tempo ou familiares de alunos que permanecem bastante tempo em certa escola.

f) Rede de relacionamento é um resultado natural de interações de logo prazo em serviços duradouros.

g) Por último, a possibilidade de escolha em coproduzir.

Alford (2015) apresenta um framework para indicar as possibilidades (opcional ou inevitável) de escolha da organização em coproduzir, tendo como condições que determinam essas possibilidades a substitutibilidade e a interdependência. A substitutibilidade representa a capacidade da organização de substituir a coprodução pelo esforço dos colaboradores se este for mais econômico, ao passo que a interdependência representa a inexistência de execução 
das tarefas da prestadora sem a execução da tarefa do usuário, ou vice-versa. O autor aponta que os fatores que determinam a interdependência são a extensão na qual o usuário monopoliza as habilidades e recursos necessários à coprodução; a centralidade da contribuição do usuário; o grau de integração entre o trabalho da organização e o do cliente; e, por último, o quanto o coprodutor está aberto a se modificar de alguma forma ao longo do consumo do serviço.

Dentre os focos das pesquisas sobre coprodução de serviços, as que avaliam seu impacto são mais raras (Vershuere et al., 2012), todavia algumas pesquisas demonstraram impacto positivo da coprodução na satisfação do consumidor (Bitner et al., 1997; Dadfar, Brege, Sarah \& Semnani, 2013). Bitner et al. (1997) a partir de estudo conduzido em diferentes serviços - vigilantes do peso, centro de saúde da mulher - identificaram maior satisfação de consumidores que foram melhor orientados quanto ao seu papel na prestação do serviço e melhor informados anteriormente e ao longo da prestação. Já Dadfar et al. (2013) identificaram que os impactos variam conforme a natureza e o contexto da prestação. Se o serviço é complexo (como a construção de uma ponte) a coprodução levou a um mau funcionamento em alguns casos, em especial quando os requisitos das construções repassados à prestadora do serviço eram inadequados. Todavia, há também casos onde os autores identificaram efeitos positivos relevantes, como no desenvolvimento de software. Na mesma linha de Bitner et al. (1997), Dafar et al. (2013) identificaram casos onde um provimento extensivo de informação para o usuário, em especial antes da prestação, teve impacto positivo na qualidade final do serviço.

Troye e Supphellen (2012) concluíram a partir dos resultados de três estudos experimentais com foco em autosserviço que a participação do usuário tem efeito positivo na sua percepção de qualidade, tanto dos insumos oferecidos pela prestadora do serviço, quanto do valor gerado. A relação entre a coprodução e a percepção de qualidade do serviço por parte do consumidor também foi resultado da pesquisa de Pestoff (2012), que concluiu que o efeito é positivo da coprodução também na percepção dos consumidores da qualidade dos serviços públicos.

Davis e Ostrom (1991) defendem a importância da coprodução ao afirmar que o serviço de educação não pode ser prestado apenas com o esforço da escola. Ressaltam insumos essenciais oriundos de usuários, a saber: 1) tempo e esforço dos estudantes; 2) tempo e esforço das famílias; e 3) recursos que os familiares e alunos gastam para adquirir os 
materiais necessários. Eles citam esse esforço, por exemplo, sendo gasto em motivar as crianças e ajudá-las a aprender. Os autores ainda tratam de uma participação semelhante à categorizada por Pestoff (2006) como política, ao afirmar que no sistema público de educação, os familiares tendem a ter poder de voto em decisões da escola - apesar de colocarem essa participação como pouco efetiva.

Segundo Pestoff (2014), se mostra essencial o desenvolvimento de pesquisas sobre coprodução que possibilitem:

a) Comparar custos e benefícios da coprodução individual, coletiva e mista no setor público, de modo a melhor entender e facilitar a coprodução sustentável;

b) Desenvolver novos modelos e métodos para melhor entender a relação entre a coprodução individual e coletiva e a mista na duração de serviços de bem-estar;

c) Comparar coprodução em diferentes serviços públicos para discernir quais melhor se encaixam na coprodução individual, coletiva e mista.

d) Comparar a participação e coprodução do cidadão para diferentes tipos de provedores de serviços, públicos, privados com e sem fins lucrativos, cooperativas, para diferenciar como aumentar a participação na forma de provimento do serviço onde esta é menor.

e) Comparar a coprodução e a participação do cidadão no provimento de serviços públicos em diferentes países em um mesmo serviço, como educação, cuidado de idosos, para diferenciar quais arranjos institucionais promovem maior participação do cidadão;

f) Comparar a sustentabilidade da coprodução do cidadão em diferentes regimes de gestão pública, como o tradicional e a Nova Gestão Pública, para entender como e por que um regime possui um desempenho melhor que o outro em facilitar e sustentar a coprodução.

g) Comparar diferentes arranjos institucionais e legais para entender se e como estes facilitam a participação e coprodução sustentável do cidadão no provimento de serviços contínuos. 


\section{MÉTODOS E TÉCNICAS DA PESQUISA}

Neste capítulo são detalhados a descrição geral da pesquisa, a caracterização do lócus, a caracterização de sujeitos e amostra, os instrumentos utilizados, além dos procedimentos de coleta, tratamento e análise dos dados.

\subsection{Descrição geral da pesquisa}

Apesar de ter surgido na década de 1970, o conceito de coprodução, as ações para incentivá-la e a circunstâncias na quais ocorre foram pouco explorados em contextos economicamente desfavoráveis. Em especial na educação pública, cujos usuários são majoritariamente cidadãos de baixa renda. Portanto, um estudo exploratório-descritivo, entendendo a coprodução do ponto de vista do provedor do serviço, representado pelo Diretor da escola, bem como por familiares de alunos, pode gerar grandes contribuições ao entendimento do tema.

A pesquisa se iniciou a partir de uma busca documental com o objetivo de entender quais as ações promovidas pelo governo de incentivo à coprodução de familiares que já foram formalizadas. Dessa forma, identificou-se a atenção dada pelo governo, tanto a nível federal quanto distrital, e das escolas à coprodução.

Para a obtenção dos dados qualitativos, a pesquisa utilizou-se a técnica da entrevista, que pode ser caracterizada como a obtenção de dados primários de uma amostra de indivíduos, cujas características, ações ou opiniões se deseja conhecer para, mediante a interpretação do pesquisador à luz da teoria e com o uso de técnicas qualitativas de análise, obter as conclusões correspondentes aos dados coletados. Foram realizadas entrevistas com a equipe de gestão de escolas responsáveis pelos anos iniciais do ensino fundamental do Brasil, atendendo aos objetivos de descrever formas de coprodução de familiares adotadas no serviço de ensino fundamental para os anos iniciais e descrever as estratégias de incentivo à coprodução. 
Alford (2015) aponta que há pouca informação quantitativa sobre a coprodução, e quase nenhuma das pesquisas que possuem esses dados promoveram surveys junto aos usuários de serviços. Para melhor descrever circunstâncias nas quais a coprodução ocorre, foi promovido um survey junto aos usuários coprodutores, no caso desta pesquisa, familiares responsáveis pelo aluno. O survey pode ser caracterizado, conforme Hair, Black, Babin, Anderson e Tatham (2005), como a obtenção de dados primários de uma grande amostra de indivíduos, cujas características, ações ou opiniões se deseja conhecer para, mediante análise quantitativa, obter as conclusões correspondentes aos dados coletados.

\subsection{Caracterização do lócus}

O ensino fundamental é, no Brasil, direito de todo cidadão, assim como a garantia desse serviço é um dever do Estado e dos responsáveis pelas crianças. Segundo a Lei de Diretrizes Básicas da Educação, essa etapa de ensino está sob responsabilidade dos estados e municípios. Todavia, a partir dos anos 2000, os municípios têm se especializado na educação infantil (crianças até cinco anos) e nos anos iniciais do ensino fundamental (6 a 10 anos), ao passo que as unidades federativas têm se especializado nos anos finais (11 a 14 anos) e no ensino médio.

O Brasil conta, segundo dados do Censo da Educação Básica realizado pelo INEP em 2014, com 115.252 escolas públicas de ensino fundamental, distribuídas em 5.570 municípios, tendo nos anos iniciais 13.025.165 alunos. Já o Distrito Federal conta com 524 escolas públicas de ensino fundamental, tendo nos anos iniciais 154.631 alunos. Este público é atendido pelas Escolas Classe, segundo o Regimento Escolar da Rede Pública de Ensino do Distrito Federal, publicado em junho de 2015:

"Escola Classe: destinada a atender os anos iniciais do ensino fundamental, podendo, excepcionalmente, oferecer a Educação Infantil: creche, pré-escola, os $6^{\circ}$ e $7^{\circ}$ anos do ensino fundamental e o $1^{\circ}$ e $2^{\circ}$ segmento da Educação de Jovens e Adultos, de acordo com as necessidades da Rede Pública de Ensino do Distrito Federal" 
O desempenho dessas escolas é mensurado pelo Índice de Desenvolvimento da Educação Básica, o IDEB, que leva em consideração em seu cálculo o resultado da Prova Brasil, realizada a cada dois anos, e o indicador de fluxo de alunos, que explicita o percentual de aprovação das turmas, calculado anualmente pelo Censo da Educação Básica.

Esse desempenho é amplamente influenciado pela forma pela a qual os usuários colaboram. Segundo Christophe, Elacqua, Martinez, Araújo e Oliveira (2015) a sociologia da educação, desde a década de 1960, entende que há um importante papel dos familiares no aprendizado. Diversas pesquisas foram realizadas com o objetivo de quantificar essa importância. A influência da coprodução no aprendizado, representado pela participação dos pais e comunidade, varia entre $43 \%$ e $66 \%$ nos estudos de Herneman e Loxley (1983), Baker, Groesling e Gerald (2002), Gamoran e Long (2007) e Chedgar e Luschei (2009), como apresentado na parte cinza das barras da

Figura 1: Comparação da explicação dos resultados escolares em diferentes estudos em pontos percentuais - adaptado de Christophe et al. (2015).

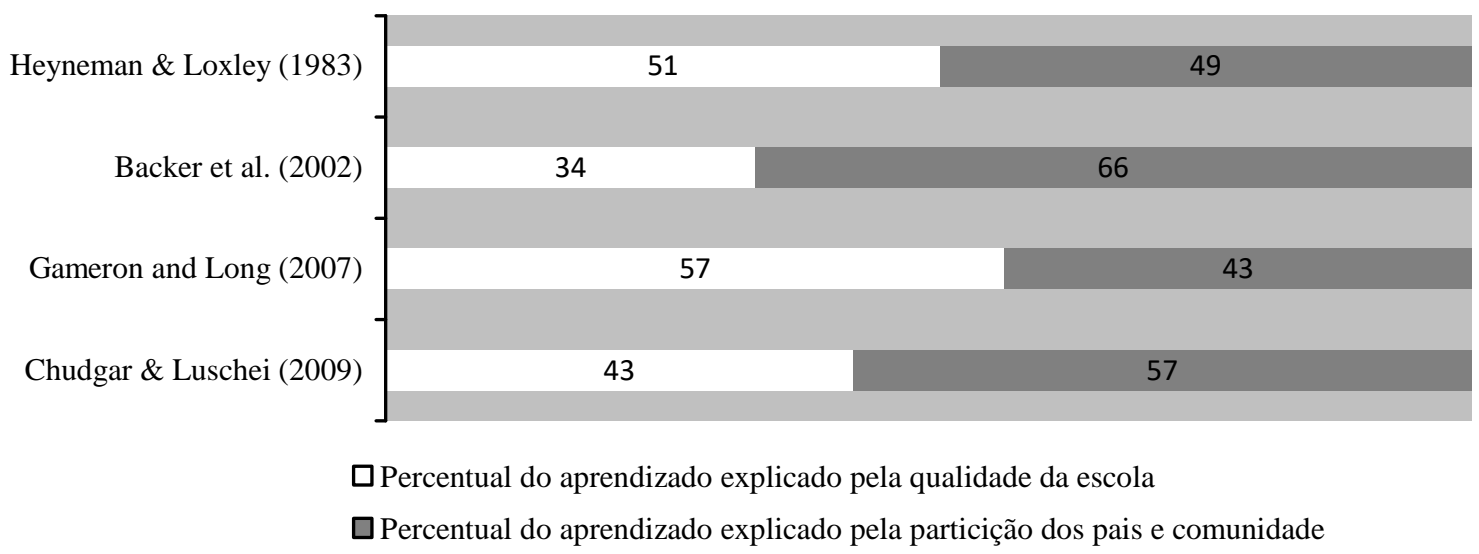

Figura 1: Comparação da explicação dos resultados escolares em diferentes estudos em pontos percentuais adaptado de Christophe et al. (2015)

Vale ressaltar que não é apenas a família quem coproduz o ensino fundamental, mas também fundações de apoio à educação, associações de pais e professores entre outros, podendo este entendimento de outros atores ser objetivo de investigações futuras (Nelson \& Gazley, 2014). 


\subsection{Procedimentos de coleta, população e amostra}

Para cumprimento do objetivo de (a) elaborar um framework de incentivos à coprodução de serviços públicos foi feita uma busca documental nos principais periódicos focados em serviços públicos.

Para (b) identificar formas pelas quais a colaboração de familiares ocorre na oferta do ensino fundamental foram utilizados os dados coletados na entrevista com gestores escolares e no survey com familiares.

Para (c) identificar políticas de incentivo à colaboração dos familiares no ensino fundamental promovidas pelos Governos Federal e do Distrito Federal foi realizada uma busca documental nos sites e publicações do Governo Federal e do Distrito Federal, cujo método é detalhado no item 3.3.1.

Para (d) identificar as ações de incentivo à coprodução do ensino fundamental promovidas pelas escolas foi realizada uma série de entrevistas com gestores escolares, cujo método é detalhado no item 3.3.2.

Para (e) verificar a relação entre o perfil do usuário e as formas de coprodução, foi realizado um survey com familiares de alunos, cujo método está descrito no item 3.3.3.

Anteriormente à coleta de dados, o projeto de pesquisa foi submetido à aprovação do Comitê de Ética da Universidade de Brasília e da Escola de Aperfeiçoamento dos Profissionais da Educação do Governo do Distrito Federal, que aprovou a pesquisa e recomendou que as escolas que concordassem, fizessem parte da amostra.

\subsubsection{Pesquisa documental}

A pesquisa se iniciou a partir de uma busca documental na qual foram utilizados sites e publicações oficiais do Ministério da Educação e da Secretaria de Educação do Distrito Federal como fontes de dados. Através dos mecanismos de buscas dessas fontes foram pesquisados os termos "pais e responsáveis", "familiares" e "família". Como resultado, chegou a 16 documentos listados no Quadro 5 - Lista de documentos analisados. 
Quadro 5 - Lista de documentos analisados

\begin{tabular}{|c|c|c|c|c|}
\hline $\begin{array}{l}\text { DOCU- } \\
\text { MENTO }\end{array}$ & NOME DO DOCUMENTO & TIPO & $\begin{array}{l}\text { POLÍTICA } \\
\text { PÚBLICA } \\
\end{array}$ & OBJETIVO DA POLÍTICA \\
\hline D1 & $\begin{array}{l}\text { Artigo } 3^{\circ} \text { da Constituição } \\
\text { Federal }\end{array}$ & $\begin{array}{l}\text { Constituição } \\
\text { Federal }\end{array}$ & Educação pública & $\begin{array}{l}\text { Definir as regras básicas da educação } \\
\text { brasileira }\end{array}$ \\
\hline D2 & $\begin{array}{l}\text { Lei } n^{\circ} 9.394, \text { de } 20 \text { de } \\
\text { dezembro de } 1996 \text { (LDB) }\end{array}$ & Lei Federal & Educação pública & $\begin{array}{l}\text { Estabelecer as diretrizes e bases } \\
\text { da educação nacional }\end{array}$ \\
\hline D3 & $\begin{array}{l}\text { Lei } n^{\circ} 8.069, \text { d } 13 \text { de junho } \\
\text { de } 1990 \text { (ECA) }\end{array}$ & Lei Federal & $\begin{array}{l}\text { Estatuto da criança } \\
\text { e do adolescente }\end{array}$ & $\begin{array}{l}\text { Dispor sobre o Estatuto da Criança } \\
\text { e do Adolescente e dar } \\
\text { outras providências }\end{array}$ \\
\hline D4 & $\begin{array}{l}\text { Lei } n^{\circ} 10.836 \text { de } 9 \text { de janeiro } \\
\text { de } 2004\end{array}$ & Lei federal & Bolsa Família & $\begin{array}{l}\text { Criar o programa Bolsa família e dá } \\
\text { outras providências }\end{array}$ \\
\hline D5 & $\begin{array}{l}\text { Decreto } 5.209 \text {, de } 17 \mathrm{de} \\
\text { setembro de } 2004\end{array}$ & $\begin{array}{l}\text { Decreto de lei } \\
\text { Federal }\end{array}$ & Bolsa Família & $\begin{array}{l}\text { Alterar artigos do programa Bolsa } \\
\text { Família }\end{array}$ \\
\hline D6 & $\begin{array}{l}\text { Decreto 6.916, de } 30 \text { de julho } \\
\text { de } 2009\end{array}$ & $\begin{array}{l}\text { Decreto de lei } \\
\text { Federal }\end{array}$ & Bolsa Família & $\begin{array}{l}\text { Alterar artigos do programa Bolsa } \\
\text { Família }\end{array}$ \\
\hline D7 & $\begin{array}{l}\text { Lei } n^{\circ} 11.947 \text {, de } 16 \text { de junho } \\
\text { de } 2009\end{array}$ & Lei Federal & $\begin{array}{l}\text { Programa Dinheiro } \\
\text { Direto na escola }\end{array}$ & $\begin{array}{l}\text { Dispor sobre o atendimento à } \\
\text { alimentação escolar e Programa } \\
\text { Dinheiro Direto na Escola }\end{array}$ \\
\hline D8 & $\begin{array}{l}\text { Manual de orientação para } \\
\text { constituição de unidade } \\
\text { executora própria }\end{array}$ & Manual & $\begin{array}{l}\text { Programa Dinheiro } \\
\text { Direto na Escola }\end{array}$ & $\begin{array}{l}\text { Descrever informações importantes } \\
\text { de serem levadas em consideração no } \\
\text { PDDE }\end{array}$ \\
\hline D9 & $\begin{array}{l}\text { Resolução n }{ }^{\circ} 03 \text {, de } 01 \text { de } \\
\text { abril de } 2010 \text { - Manual } \\
\text { operacional do programa } \\
\text { escola aberta }\end{array}$ & Manual & $\begin{array}{l}\text { Escola de Porta } \\
\text { Aberta }\end{array}$ & $\begin{array}{l}\text { Descrever informações importantes } \\
\text { de serem levadas em consideração no } \\
\text { Escola de Porta Aberta }\end{array}$ \\
\hline D10 & $\begin{array}{l}\text { Relatório de atividades } \\
\text { 2008/2011 }\end{array}$ & Relatório & $\begin{array}{l}\text { Mobilização Social } \\
\text { pela Educação }\end{array}$ & $\begin{array}{l}\text { Relatar os avanços da Mobilização } \\
\text { Social pela Educação }\end{array}$ \\
\hline D11 & $\begin{array}{l}\text { Resolução } n^{\circ} 3 \text {, de } 1^{\circ} \text { de abril } \\
\text { de } 2010\end{array}$ & Resolução & $\begin{array}{l}\text { Programa Dinheiro } \\
\text { Direto na Escola e } \\
\text { Escola de Porta } \\
\text { Aberta }\end{array}$ & $\begin{array}{l}\text { Dispõe sobre os processos de adesão } \\
\text { e habilitação e as formas de execução } \\
\text { e prestação de contas referentes ao } \\
\text { Programa Dinheiro Direto na Escola } \\
\text { (PDDE), e dá outras providências }\end{array}$ \\
\hline D12 & $\begin{array}{l}\text { Lei Distrital } \mathrm{n}^{\circ} 449 \text { de } 17 \text { de } \\
\text { maio de } 1993\end{array}$ & Lei Distrital & $\begin{array}{l}\text { Abono dos } \\
\text { familiares por } \\
\text { reunião de pais }\end{array}$ & $\begin{array}{l}\text { Instituir Abono de Ponto Bimestral, } \\
\text { para pais e responsáveis de crianças } \\
\text { em idade escolar. }\end{array}$ \\
\hline D13 & Projeto de lei $s / n^{\circ}$ de 2015 & $\begin{array}{l}\text { Projeto de Lei } \\
\text { Federal }\end{array}$ & $\begin{array}{l}\text { Abono dos } \\
\text { familiares por } \\
\text { reunião de pais }\end{array}$ & $\begin{array}{l}\text { Dispõe sobre o acompanhamento } \\
\text { pedagógico de crianças e } \\
\text { adolescentes na escola pelos pais ou } \\
\text { responsáveis legais }\end{array}$ \\
\hline D14 & $\begin{array}{l}\text { Projeto Político Pedagógico } \\
\text { Professor Carlos Mota - } \\
\text { SEEDF }\end{array}$ & $\begin{array}{l}\text { Projeto } \\
\text { Político } \\
\text { Pedagógico }\end{array}$ & Educação Pública & $\begin{array}{l}\text { Planejar, orientar e construir } \\
\text { diretrizes para a rede pública de } \\
\text { ensino do Distrito Federal }\end{array}$ \\
\hline D15 & $\begin{array}{l}\text { Planejamento estratégico da } \\
\text { SEEDF 2015-2018 }\end{array}$ & $\begin{array}{l}\text { Planejamento } \\
\text { Estratégico }\end{array}$ & Educação Pública & $\begin{array}{l}\text { Definir a visão, a missão, os } \\
\text { objetivos estratégicos, as estratégias } \\
\text { e as metas desta Secretaria para o } \\
\text { desenvolvimento da Educação }\end{array}$ \\
\hline D16 & $\begin{array}{l}\text { Relatório de Gestão SEEDF } \\
2015\end{array}$ & $\begin{array}{l}\text { Relatório de } \\
\text { Gestão }\end{array}$ & Educação Pública & $\begin{array}{l}\text { Relatar os avanços das políticas } \\
\text { públicas de educação do Distrito } \\
\text { Federal }\end{array}$ \\
\hline
\end{tabular}

\subsubsection{Entrevista com gestores escolares}

O artigo $7^{\circ}$ da seção III do Regimento Escolar da Rede Pública de Ensino do Distrito

Federal, publicado em junho de 2015, descreve que "a equipe gestora é composta por Diretor, Vice-diretor, Supervisores e Chefe de Secretaria, conforme a modulação de cada unidade 
escolar, em consonância com as deliberações do Conselho Escolar, respeitadas as disposições legais". Ou seja, o papel de gestão na escola é dividido por quatro perfis profissionais, variando conforme a escola. Dessa forma, o profissional entrevistado a cada unidade foi definido conforme a distribuição de atribuições. Em suma, foram entrevistados os gestores responsáveis pelo engajamento de familiares nas atividades educacionais.

A população de gestores escolares municipais de escolas responsáveis pelos anos iniciais do ensino fundamental, segundo a Censo da Educação Básica de 2014 é de 574 em todo o Distrito Federal.

Quadro 6 - Quantidade de escolas por Coordenação Regional de Ensino do GDF (fonte: Relatório de gestão de 2014)

\begin{tabular}{llll}
\hline $\begin{array}{l}\text { COORDENAÇÃO REGIONAL DE } \\
\text { ENSINO }\end{array}$ & $\begin{array}{l}\text { QUANTIDADE } \\
\text { ESCOLAS }\end{array}$ & $\begin{array}{l}\text { DE } \\
\text { DE ENSINO }\end{array}$ & $\begin{array}{l}\text { QUEANTIDADE } \\
\text { DEE ESCOLAS }\end{array}$ \\
\hline BRAZLÂNDIA & 29 & RECANTO DAS EMAS & 29 \\
\hline CEILÂNCIA & 98 & SÃO SEBASTIÃO & 23 \\
\hline GAMA & 49 & SAMAMBAIA & 49 \\
\hline GUARÁ & 27 & SANTA MARIA & 31 \\
\hline NÚCLEO BANDEIRANTE & 32 & SOBRADINHO 1 e 2 & 37 \\
\hline PARANOÁ & 31 & TAGUATINGA & 63 \\
\hline
\end{tabular}

Para chegar aos gestores foi selecionada uma escola por coordenação regional de ensino e a mesma foi contatada por telefone para marcação de entrevista presencial conduzida pelo pesquisador. Para as escolas cujo contato telefônico não teve sucesso, foi escolhida outra unidade da mesma coordenação regional.

Para garantir respostas de diferentes contextos foi selecionada aleatoriamente uma escola em cada uma das 14 coordenações regionais de ensino. Para tanto, utilizou-se a ferramenta Microsoft Excel, com a fórmula "ALEATÓRIOENTRE”, que gera um valor inteiro aleatório entre limites previamente definidos, superior e inferior. O limite superior definido foi igual à quantidade de escolas da regional de ensino, conforme apresentado na Quadro 6 - Quantidade de escolas por Coordenação Regional de Ensino do GDF (fonte: Relatório de gestão de 2014), e o inferior, igual a um. As regionais de ensino são diversas quanto ao contexto socioeconômico, com regionais de grupos com níveis de renda superiores, 
como Plano Piloto e Cruzeiro, e de grupos com níveis de renda inferiores, como Recanto das Emas. Dessa forma, escolhendo uma escola por coordenação regional, esperou-se coletar insumos para a pesquisa que abrangendo a diversidade do Distrito Federal. O critério de escolha da escola dentro da coordenação regional, aleatório, tem como objetivo retirar qualquer viés que um possível critério, como nível socioeconômico da escola ou resultado de aprendizagem, poderia trazer.

Após o contato com as 14 primeiras escolas selecionadas, oito aceitaram participar da pesquisa, três se negaram alegando indisponibilidade da equipe de gestão, e três não atenderam às ligações. Das seis levantadas no segundo sorteio, duas aceitaram participar da pesquisa, três se negaram por indisponibilidade e uma não atendeu às ligações. Na terceira seleção aleatória de escolas, das quatro selecionadas, duas atenderam à ligação, mas não aceitaram participar. A amostra foi fechada com as dez escolas que aceitaram participar. Uma das escolas solicitou a remarcação da entrevista por seis vezes, tornando-se inviável a sua participação, e uma das escolas que havia se colocado como indisponível, reconsiderou sua participação, resultando na participação de duas escolas da mesma Coordenação Regional de Ensino. Dessa forma, a amostra da pesquisa contemplou dez escolas públicas de ensino fundamental do Distrito Federal, representando nove coordenações regionais de ensino. $\mathrm{O}$ Quadro 7 - Perfil de gestores escolares entrevistados, a seguir, apresenta o perfil dos gestores escolares entrevistados, dispostos conforme a ordem de realização das entrevistas, considerando sua função na escola, gênero, idade, experiência e o código a ele atribuído para realização de menções ao longo da análise de conteúdo e das discussões de resultados.

Quadro 7 - Perfil de gestores escolares entrevistados

\begin{tabular}{lllccc}
\hline ESCOLA & FUNÇão & GÊNERO & IDADE & EXPERIÊNCIA & $\begin{array}{c}\text { CóDIGO DO } \\
\text { GESTOR }\end{array}$ \\
\hline Escola 1 & Diretor & Masculino & 40 & 10 & G.E.1 \\
\hline Escola 2 & Diretor & Feminino & 46 & 6 & G.E.2 \\
\hline Escola 3 & Vice-diretor & Feminino & 42 & 6 & G.E.3 \\
\hline Escola 4 & Diretor & Feminino & 46 & 16 & G.E.4 \\
\hline Escola 5 & Diretor & Feminino & 52 & 15 & G.E.5 \\
\hline Escola 6 & Diretor & Masculino & 51 & 25 & G.E.6 \\
\hline
\end{tabular}




\begin{tabular}{llllll}
\hline Escola 7 & Diretor & Feminino & 36 & 3 & G.E.7 \\
\hline Escola 8 & Diretor & Feminino & 56 & 8 & G.E.8 \\
\hline Escola 9 & $\begin{array}{l}\text { Supervisor } \\
\text { Pedagógico }\end{array}$ & Feminino & 43 & 17 & G.E.9 \\
\hline Escola10 & Vice-diretor & Feminino & 52 & 8 & G.E.10 \\
\hline
\end{tabular}

Para a obtenção da percepção de gestores escolares quanto à coprodução dos familiares, as entrevistas foram realizadas a partir do roteiro descrito no item 3.5.

\subsubsection{Survey realizado com participantes que eram familiares de alunos}

Para atender ao objetivo específico de verificar a relação entre o perfil do usuário e as formas de coprodução de familiares dos alunos do ensino fundamental, foi aplicado um survey. Após a seleção de dez escolas públicas entre nove coordenações regionais de ensino do Distrito Federal para terem seus respectivos gestores entrevistados, foi questionado a estes sobre possibilidade de aplicação do questionário. A aplicação se deu por dois meios, o envio do questionário impresso para a família, via agenda dos alunos, e a entrega do questionário aos familiares nas reuniões de pais. A escolha do meio pelo qual o questionário foi aplicado, bem como da quantidade de questionários a serem aplicados, foi feita pelo gestor escolar entrevistado. No total foram distribuídos 720 questionários, dos quais retornaram 270 respondidos. Cabe ressaltar o possível viés gerado pelo método de coleta, uma vez que tanto a presença na reunião de pais, quanto as respostas às comunicações feitas pelas agendas dos alunos, tendem a ser atitudes de familiares mais engajados com a educação, entretanto, tal limitação do estudo se mostrou inevitável frente às condições estabelecidas pelos gestores escolares. 


\subsection{Instrumentos de Coleta}

Para atender aos objetivos de entendimento das políticas de incentivo e das formas de coprodução na educação foram realizadas as entrevistas com a equipe de gestão de escolas. Para tanto, foram utilizados o Termo de Consentimento Livre e Esclarecido e o roteiro de entrevista - expostos no Apêndice A, elaborado com base nos estudos anteriores sobre coprodução de serviços públicos, coprodução na educação e incentivos à coprodução, a citar: Alford et al. (2002, 2009, 2015), Parrado, Van Ryzin, Bovaird e Loeffler (2013), Loeffler et al. (2008), Bovaird et al. (2014, 2015), Pestoff (2006), Ostrom (1996), Bitner et al. (1997) e Dafar et al. (2013). O roteiro foi dividido em duas partes: itens contextuais e itens sobre formas e incentivo à coprodução.

Para atender aos objetivos de verificar a relação entre perfil do usuário com as formas de coprodução de familiares dos alunos do ensino fundamental, foram utilizados o Termo de Consentimento Livre e Esclarecido e o questionário - expostos no Apêndice $\mathrm{B}$, que conterá duas partes, a saber: a primeira levantou o perfil sociodemográfico de familiares responsáveis pelos alunos; a segunda levantou as formas de coprodução por meio das quais os familiares e/ou responsáveis de aluno atualmente colaboram.

\subsection{Procedimentos de Análise dos Dados}

Os dados oriundos da pesquisa documental, por sua natureza qualitativa, foram objeto de análise documental, o que Bardin (2009, p. 45) coloca como "uma operação ou um conjunto de operações visando representar o conteúdo de um documento sob uma forma diferente da original, a fim de facilitar num estado ulterior, a sua consulta e referenciação". Esse método permitiu a identificação, compilação e interpretação dos documentos identificados, e dessa forma a caracterização do serviço, a identificação dos elementos constituintes da coprodução e as formas pelas quais ela é incentivada.

A análise de conteúdo foi utilizada na análise dos dados oriundos das entrevistas visando atender os objetivos de identificar as formas de incentivo das escolas, bem como as formas de coprodução da educação por parte das famílias. As formas de incentivo foram 
divididas em duas análises, uma abordando os mecanismos formais de incentivo à coprodução, ou seja, aquelas motivadas e regidas por leis; e em estratégias de incentivo à coprodução, aquelas motivadas pelas decisões da equipe gestora da escola e não regidas por legislação.

A análise de conteúdo fundamentou a saturação teórica do estudo, uma vez que a análise foi realizada à medida que as entrevistas ocorriam, com o objetivo de identificar o momento no qual "a entrevista ou a observação não acrescenta nada ao que já se conhece sobre o fenômeno ou categoria investigado (saturação teórica), suas propriedades e suas relações com outras categorias" (Thiry-Cherques, 2009, p. 22).

Cada análise passou por duas etapas, sendo a primeira um levantamento na literatura sobre o objeto e realização de uma categorização. Nota-se que, uma vez que esse procedimento foi realizado antes da coleta dos dados, é considerado como uma análise $a$ priori (Thiry-Cherques, 2009). De posse dos dados, foi realizada a análise de conteúdo das entrevistas em busca da confirmação das categorias já identificadas e a inclusão de novas até a saturação teórica - categorização a posteriori (Thiry-Cherques, 2009). Segundo Bardin (2009, p. 119), "a categorização tem como primeiro objetivo fornecer, por condensação, uma representação simplificada dos dados brutos".

A análise estatística dos dados foi realizada com o programa IBM SPSS (Statistical Package for the Social Sciences), versão 22 para Windows. As variáveis quantitativas foram caraterizadas através da média e desvio-padrão e as qualitativas através de frequências absolutas e relativas.

Para a análise da significância das associações entre variáveis foram utilizados os testes de independência do Qui-quadrado (associação entre duas variáveis qualitativas) e o Coeficiente de Correlação de Spearman (correlação entre pelo menos duas variáveis ordinais. Foi também utilizado o Teste de Wilcoxon para comparar a distribuição das variáveis coprodução coletiva e coprodução individual.

$\mathrm{O}$ estudo dos fatores que influenciam as diferentes formas de coprodução foi feito com modelos de regressão. No caso em que a variável dependente era quantitativa, foram utilizados modelos de regressão linear, após a verificação normalidade através dos coeficientes de assimetria e curtose (foram considerados os critérios referidos por Marôco (2011): valores dos coeficientes inferiores a 1 garantem a aproximação à normalidade). Quando a variável dependente era dicotômica, foram utilizados modelos de regressão logística. 
Para a decisão quanto aos resultados dos testes estatísticos foi considerado um nível de significância de $5 \%(\mathrm{p}<0.05)$.

No tratamento da base de dados, houve a exclusão de um caso por só ter como registros os dados relativos às variáveis de perfil sociodemográfico. 


\subsection{Quadro resumo da métodos e técnicas de pesquisa}

Quadro 8 - Resumo da metodologia

\begin{tabular}{|c|c|c|c|c|c|}
\hline ETAPA & OBJETIVOS & FONTES DOS DADOS & TIPO DE DADO COLETADO & TÉCNICA DE COLETA & TÉCNICA DE ANALISE \\
\hline 1 & $\begin{array}{l}\text { Elaborar framework de incentivo à } \\
\text { coprodução de serviços públicos }\end{array}$ & $\begin{array}{l}\text { Literatura de coprodução de } \\
\text { serviços públicos }\end{array}$ & $\begin{array}{l}\text { Artigos publicados em } \\
\text { periódicos }\end{array}$ & Pesquisa documental & Análise de conteúdo \\
\hline 2 & $\begin{array}{l}\text { Identificar políticas de incentivo à } \\
\text { colaboração de familiares de alunos } \\
\text { do ensino fundamental promovidas } \\
\text { pelos governos federal e distrital }\end{array}$ & $\begin{array}{l}\text { Leis, sites do poder } \\
\text { executivo (MEC e } \\
\text { Secretaria do GDF) }\end{array}$ & $\begin{array}{l}\text { Políticas de incentivo à } \\
\text { colaboração da família }\end{array}$ & Pesquisa documental & Análise de conteúdo \\
\hline 3 & $\begin{array}{l}\text { Descrever as ações de incentivo à } \\
\text { coprodução do ensino fundamental } \\
\text { promovidas por escolas }\end{array}$ & Gestores escolares & $\begin{array}{l}\text { Ações promovidas pela direção } \\
\text { da escola para o incentivo à } \\
\text { colaboração da família }\end{array}$ & $\begin{array}{l}\text { Entrevista } \\
\text { semiestruturada com } \\
\text { gestores escolares }\end{array}$ & $\begin{array}{l}\text { Análise de conteúdo das } \\
\text { entrevistas }\end{array}$ \\
\hline 4 & $\begin{array}{l}\text { Identificar as formas pelas quais a } \\
\text { colaboração de familiares no ensino } \\
\text { fundamental ocorre }\end{array}$ & $\begin{array}{l}\text { Gestores escolares } \\
\text { (diretores ou vice-diretores) } \\
\text { e Familiares de alunos }\end{array}$ & $\begin{array}{l}\text { Percepção dos coprodutores e } \\
\text { gestores escolares quanto à } \\
\text { forma de coprodução de cada } \\
\text { usuário }\end{array}$ & $\begin{array}{l}\text { Entrevista } \\
\text { semiestruturada com } \\
\text { gestores escolares; } \\
\text { Survey com familiares }\end{array}$ & $\begin{array}{l}\text { Análise de conteúdo e } \\
\text { Estatística descritiva }\end{array}$ \\
\hline 5 & $\begin{array}{l}\text { Verificar influência do perfil do } \\
\text { usuário nas formas de coprodução }\end{array}$ & Familiares de alunos; & $\begin{array}{l}\text { Perfil dos coprodutores e forma } \\
\text { de coprodução }\end{array}$ & $\begin{array}{l}\text { Survey com familiares } \\
\text { dos alunos }\end{array}$ & $\begin{array}{l}\text { Estatística descritiva; } \\
\text { regressão linear e } \\
\text { logística }\end{array}$ \\
\hline
\end{tabular}




\section{RESULTADOS E DISCUSSÕES}

Os resultados da pesquisa foram divididos em duas partes, a primeira tratando dos objetivos específicos que tangem ao incentivo à coprodução da educação pública - (a) elaborar um framework de entendimento dos incentivos à coprodução de serviços públicos; (b) identificar formas pelas quais a colaboração de familiares ocorre na oferta do ensino fundamental; (c) identificar políticas de incentivo à colaboração dos familiares no ensino fundamental promovidas pelos governos federal e do distrito federal, (d) identificar as ações de incentivo à coprodução do ensino fundamental promovidas pelas escolas; e a segunda parte tratando dos objetivos que abordam as formas de coprodução e sua relação com o perfil dos usuários do serviço e (e) verificar a influência do perfil do usuário nas formas de coprodução.

\subsection{Framework demonstrativo do incentivo à coprodução na educação pública}

Foi identificada a existência de três níveis de incentivo às diversas formas de coprodução da educação pública por parte de familiares de alunos: as políticas governamentais, geradas pelas esferas superiores do governo (federal e distrital) e materializados em leis, estatutos, regimentos, entre outros (Ostrom, 1996; Alford, 2009); os mecanismos formais, resultantes dessas regulamentações, adaptados e implementados pelas escolas (Pestoff, 2006, Thaler e Sunstein 2009; John et al., 2009); e as estratégias empreendidas pelas escolas de forma independente às políticas promovidas pelo governo (Ostrom, 1996; Thaler e Sunstein 2009; John et al., 2009; Bovaird et al. 2015).

A despeito do esforço promovido pelo setor público, a literatura mostra que as formas de coprodução são amplamente influenciadas pelo perfil dos usuários do serviço, como apresentado por Pestoff (2012), Bovaird et al. (2015), Alford e Yates (2015), Rosentraub e Sharp (1981), Pestoff (2006) e Alves et al. (2013).

Nesse contexto, para compreender o incentivo de governo e de escolas à coprodução do ensino fundamental público, se mostra necessário entender: (A) as políticas governamentais de incentivo; (B) os mecanismos formais e as estratégias adotadas pela escola; (C) o perfil dos usuários; e (D) a forma pela qual os usuários coproduzem, como apresentado na Figura 2: Framework de incentivo à coprodução da educação pública. Para 
construir o framework cada conjunto de variáveis foi colocado em uma caixa e as setas representam a direção de influência de dessas variáveis, ou seja, as políticas governamentais influenciam os mecanismos formais de incentivo à coprodução, que, junto das estratégias das escolas e do perfil dos usuários, influenciam as formas de coprodução. É importante ressaltar que neste estudo apenas a influência do perfil do usuário nas formas de coprodução está sendo abordada estatisticamente.

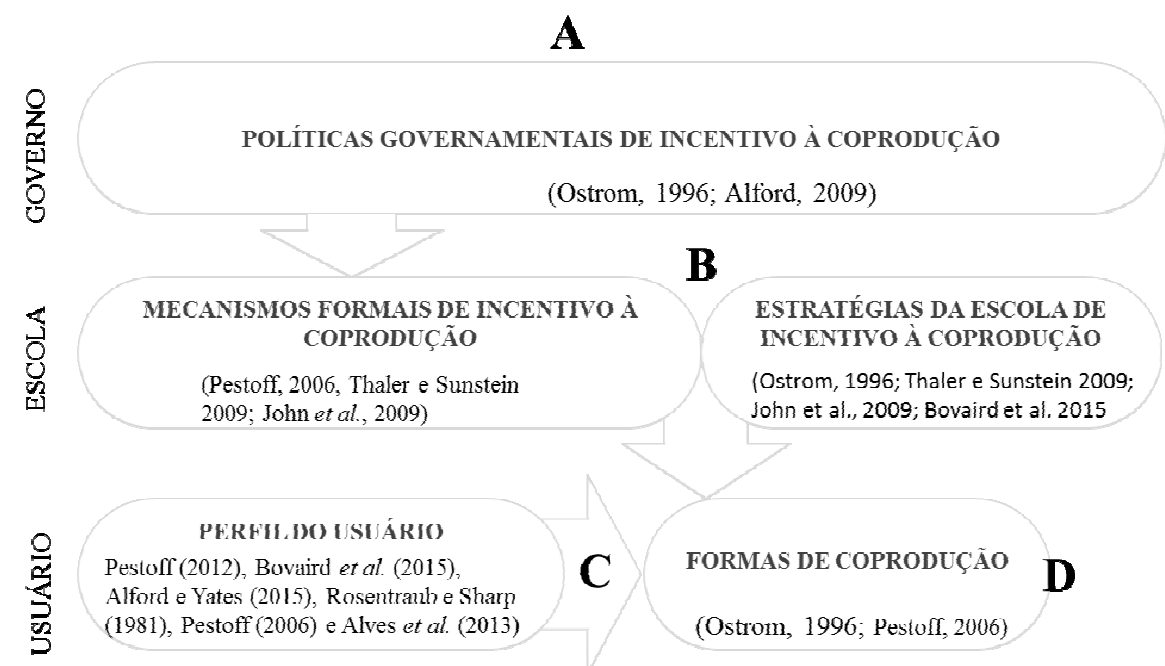

Figura 2: Framework de incentivo à coprodução da educação pública

\subsection{Formas de coprodução da oferta do ensino fundamental por familiares de alunos}

Com o objetivo de identificar formas pelas quais a coprodução de familiares ocorre na oferta do ensino fundamental, perguntou-se a gestores escolares se os familiares de alunos participam do processo educacional e quais as formas dessa participação. Para a análise dos resultados foi realizada uma categorização a priori, utilizando o que Pestoff (2006) identificou como quatro tipos de contribuição de familiares para a educação de alunos: econômicas, políticas, pedagógicas e sociais. Davis e Ostrom (1991) ressaltam insumos essenciais para o serviço oriundos dos familiares, a saber: tempo e esforço das famílias coprodução pedagógica e econômica; recursos gastos para adquirir os materiais necessários coprodução econômica; e escolhendo e votando em decisões da escola - coprodução política.

O entrevistado G.E.1 relatou formas de participação dos familiares dentro das quatro categorias delineadas com base em Pestoff (2006). Dentro do que o autor coloca como 
coprodução econômica o gestor escolar citou a participação a partir da doação em dinheiro para a escola. Os familiares doam certa quantia no início do ano para prover recursos que são despendidos sob chancela da associação de pais e mestres. Pestoff (2006) ainda explica que a contribuição econômica extrapola a doação em espécie, e inclui tempo e esforço, além de outros materiais necessários para a escola funcionar plenamente. Ostrom (1996) também identificou essa categoria de coprodução ao estudar a educação primária nigeriana, onde havia vários projetos empreendidos por familiares para melhorar a estrutura física e condições sanitárias das escolas.

Quanto à categoria de coprodução política, que é apresentada por Pestoff (2006) como a participação dos familiares nas tomadas de decisão institucionais (que impactam na escola) e individuais (que impactam no aluno), foi identificada pelo entrevistado a existência do conselho escolar. Segundo o gestor G.E.1 o conselho escolar desempenha o papel de tomar decisões relevantes para a escola, como aprovação de orçamentos e prestação de contas, tendo entre seus sete representantes: professores, gestores e funcionários da escola, além de familiares dos alunos. Ostrom (1996) identificou em um estudo de caso relativo ao serviço de saneamento no Brasil a importância do amplo provimento de informação aos cidadãos, bem como da participação dos mesmos no planejamento do serviço. A autora ainda concluiu que a coprodução é desencorajada quando o governo é centralizador, evidenciando o impacto positivo da coprodução política nas demais, uma vez ao passo que uma vez que o cidadão tem um sentimento de dono quanto ao serviço, tende a colaborar mais.

O entrevistado G.E.1 apresentou formas de coprodução da educação dentro da categoria que Pestoff (2006) coloca como pedagógica. A participação pedagógica dos pais é fenômeno natural, à medida que o crescimento e aprendizado do estudante é, em grande parte, impactado pelo relacionamento com os familiares em casa (Christophe et al., 2015). O autor ainda extrapola o ambiente do lar ao defender que a coprodução pedagógica se dá também na escola, uma vez que a família pode participar de atividades nas aulas ou atividades complementares de ensino. As formas de coprodução da categoria listadas pelo gestor G.E.1 foram a comunicação pela agenda, onde os familiares por vezes realizam atividades junto aos alunos que geram aprendizado, assim como a reunião de pais, onde os familiares conversam com a professores e juntos definem as melhores formas de fazer o aprendizado da criança acontecer. 
A última categoria proposta por Pestoff (2006) - coprodução social da educação -, foi evidenciada na entrevista pela participação da família em eventos da escola. O G.E.1 apontou que a participação da família em eventos promovidos pela escola, como festas juninas, das mães e de fim de ano, é muito importante para o clima escolar. Pestoff (2006) explica que essa coprodução pode ocorrer de diversas formas, como o auxílio na organização desses eventos, trazendo outros membros da comunidade (vizinhos), ou apenas estando presente nos momentos de integração promovidos pela escola. Apenas o último caso foi relatado pelo G.E.1.

Além de relatar estratégias referentes às quatro formas identificadas por Pestoff (2006), o G.E.1 enfatizou a importância de outra forma de coprodução, o que ele chamou de "amparo" e "rede de proteção", na qual os familiares tratam do provimento de cuidados básicos para o aluno.

"As crianças que apresentam dificuldades, se a família não
está junto dessa criança com uma rede de proteção na área de
saúde, médica, psicológica, com os professores, com o
reforço escolar, as crianças não vão vencer essas
dificuldades." (G.E.1)

O entrevistado ainda trouxe à tona outra ação correlata da família, que na sua opinião é essencial para a escola: trazer para os professores e pedagogos problemas do aluno fora da escola, mas que impactam no aprendizado. É visível nessas preocupações trazidas pelo G.E.1 a necessidade de participação da família provendo o suporte básico para o aluno, que a priori poderia ser entendida como algo tão trivial que qualquer familiar proveria - o que não ocorre de fato. Dessa forma, se mostrou necessário o delineamento de outra categoria de forma de coprodução dos familiares, não identificada no estudo em oito países europeus por Pestoff (2006), a "Coprodução por Suporte Básico”. Uma hipótese a ser verificada em estudos futuros é a de que essa categoria não foi evidenciada em países com nível socioeconômico alto devido ao fato de neste contexto esse tipo de participação não é uma variável, sendo plenamente provido por todos os familiares de alunos do ensino fundamental.

Da entrevista com o G.E.2, até a entrevista com o, G.E.5, nenhuma categoria foi incluída. O G.E.6 confirmou as cinco categorias previamente identificadas. A econômica, por meio da contribuição em espécie para a Associação de Pais e Mestres, que é feita por cerca de um décimo das famílias. A política, por meio da participação nas decisões do Conselho Escolar, Associação de pais e mestres e Assembleia Geral. A pedagógica, por meio do acompanhamento e auxílio nas atividades de casa do aluno. A social, por meio da participação em festas e eventos em geral, além da coprodução pelo suporte básico, por meio de 
provimento dos valores básicos necessários para a criança conviver bem na escola, como o respeito ao próximo. Essa última foi ressaltada pelo gestor escolar 6 como uma participação muito importante do ponto de vista da escola. Dentro do suporte básico, o gestor escolar citou o provimento de amparo por meio de consultas médicas e remédios aos alunos que possuem essas necessidades. Por último, foi identificada uma forma de coprodução que não se encaixou em nenhuma das categorias previamente delineadas. Foram relatados casos de grupos de familiares (mães de alunos) que se uniram para fazer pressão em autoridades do governo para conseguir recursos necessários para a escola, num caso relatado, transporte escolar. Dessa forma, foi delineada a categoria coprodução por influência.

$\mathrm{Na}$ sexta entrevista foi alcançada a saturação teórica da categoria, uma vez que nas quatro seguintes nenhuma nova categoria foi identificada, como apresentado no Quadro 13.

Quadro 9 - Registro da inclusão e confirmação de categorias de formas de coprodução da educação pública

\begin{tabular}{|c|c|c|}
\hline CATEGORIA & INCLUIU & CONFIRMOU \\
\hline Entrevista 1 & 5. Suporte Básico & $\begin{array}{l}\text { 1. Econômica } \\
\text { 2. Política } \\
\text { 3. Pedagógica } \\
\text { 4. Social }\end{array}$ \\
\hline Entrevista 2 & & $\begin{array}{l}\text { 2. Política } \\
\text { 3. Pedagógica } \\
\text { 4. Social } \\
\text { 5. Suporte básico }\end{array}$ \\
\hline Entrevista 3 & & $\begin{array}{l}\text { 1. Econômica } \\
\text { 2. Política } \\
\text { 3. Pedagógica } \\
\text { 4. Social }\end{array}$ \\
\hline Entrevista 4 & & $\begin{array}{l}\text { 2. Política } \\
\text { 3. Pedagógica } \\
\text { 4. Social }\end{array}$ \\
\hline Entrevista 5 & & $\begin{array}{l}\text { 2. Política } \\
\text { 3. Pedagógica } \\
\text { 4. Social } \\
\text { 5. Suporte básico }\end{array}$ \\
\hline Entrevista 6 & 6. Influência & $\begin{array}{l}\text { 1. Econômica } \\
\text { 2. Política } \\
\text { 3. Pedagógica } \\
\text { 4. Social } \\
\text { 5. Suporte básico }\end{array}$ \\
\hline
\end{tabular}




\begin{tabular}{ll}
\hline Entrevista 7 & 3. Pedagógica \\
& 4. Social \\
& 5. Suporte básico \\
& \\
\hline Entrevista 8 & 2. Política \\
& 3. Pedagógica \\
& 4. Social \\
& 5. Suporte básico \\
\hline Entrevista 9 & 3. Pedagógica \\
& 4. Social \\
& \\
\hline Entrevista 10 & 3. Pedagógica \\
& 4. Social \\
\hline
\end{tabular}

As quatro categorias propostas por Pestoff (2006) foram confirmadas, a econômica em quatro entrevistas, a política em oito, a pedagógica e a social em 10. Foi identificada ainda a categoria suporte básico, que teve formas de coprodução explícitas em seis das 10 entrevistas, mostrando sua relevância do ponto de vista dos gestores escolares. Dentro de cada categoria foram identificadas diversas formas de coprodução de familiares como apresentado no Quadro 10 - Relação de categorias e exemplos observados de formas de coprodução da educação pública.

Quadro 10 - Relação de categorias e exemplos observados de formas de coprodução da educação pública

\begin{tabular}{lllllll}
\hline CATEGORIAS & $\begin{array}{l}\text { ECONÔMICA } \\
\text { (Pestoff, 2006) }\end{array}$ & $\begin{array}{l}\text { POLÍTICA } \\
\text { (Pestoff, 2006) }\end{array}$ & $\begin{array}{l}\text { PEDAGÓGICA } \\
\text { (Pestoff, 2006) }\end{array}$ & $\begin{array}{l}\text { SOCIAL } \\
\text { (Pestoff, 2006) }\end{array}$ & $\begin{array}{l}\text { SUPORTE } \\
\text { BÁSICO }\end{array}$ & $\begin{array}{l}\text { INFLUÊN } \\
\text { CIA }\end{array}$ \\
\hline
\end{tabular}




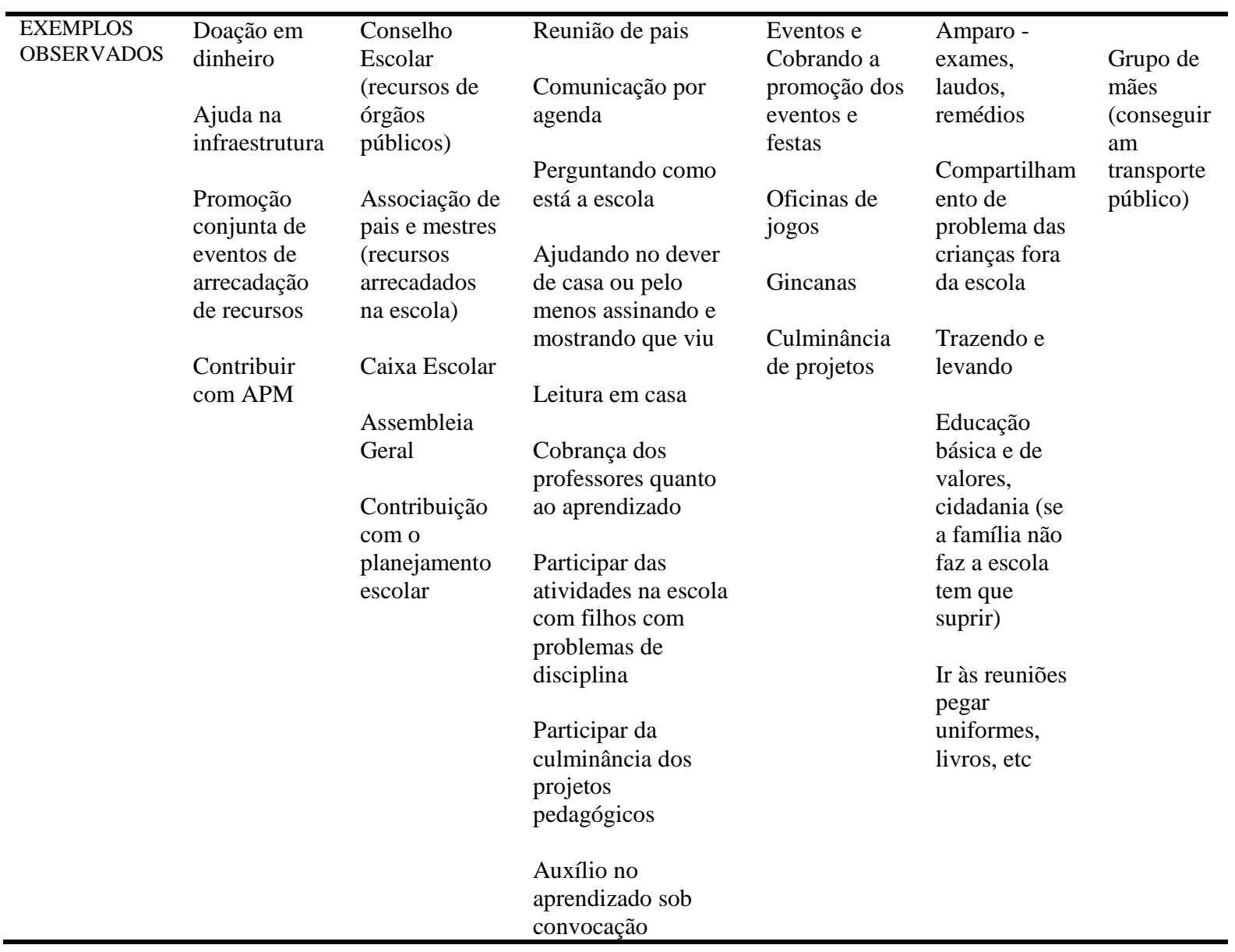

Para entender essas formas de coprodução da educação se mostra pertinente a observação sob diversas perspectivas já utilizadas na literatura, como o nível de interação entre os envolvidos - individual (com benefício ao usuário coprodutor), com grupos (envolvendo várias pessoas, podendo necessitar de coordenação e beneficiando mais de um usuário) e coletiva (coordenada e beneficiando todos os potenciais usuários do serviço) incialmente estudada por Brudney e England (1983); voluntária ou involuntária, como apresentado por Alford (2009) e Osborne (2016); e opcional ou inevitável, como apresentado por Alford (2015).

Os recursos da educação pública no Brasil devem ser plenamente providos pelo estado, que tem o dever de garantir que o serviço ocorra. Desde a construção das escolas, fornecimento de equipe pedagógica, aquisição de equipamentos até a manutenção da estrutura estão sob responsabilidade do governo. Mesmo neste contexto, os gestores escolares entrevistados apontaram a necessidade imperativa de captação de recursos alternativos, uma vez que todo o recurso oriundo de órgãos públicos responsáveis pela educação deve ser planejado com grande antecedência e tem seu destino rigidamente definido. Nas escolas 
públicas, entretanto, a demanda por recursos pode não ser tão previsível, seja devido à quebra de algum equipamento, seja devido à necessidade de aquisição de materiais para alguma atividade pedagógica não planejada com antecedência. Assim as escolas buscam recursos com o ator com o qual estão envolvidas, que tem maior interesse no sucesso do serviço - os familiares dos alunos.

Dentre as entrevistas surgiram como exemplos de contribuição econômica (Pestoff, 2006) a doação em dinheiro diretamente para a escola, a ajuda na infraestrutura por meio de doações de materiais e serviços, bem como na promoção de eventos de arrecadação recursos, como bazares, festas juninas, entre outros. Naturalmente, a própria participação desses familiares nessas festas foi apontada como uma importante fonte de recursos para as escolas.

Nota-se que ao analisar a coprodução econômica sob a perspectiva de Brudney e England (1983), ela se enquadra primariamente como individual, uma vez que cada familiar tem seu próprio recurso para prover, apesar de também ocorrer em grupo, nas promoções de eventos de arrecadação. Sob a perspectiva da voluntariedade (Alford, 2009), esta forma de coprodução pende fortemente para o espectro voluntário, uma vez que não há obrigação alguma do familiar em coproduzir. Por último, nota-se que, uma vez que a escola já possui recursos e serviço providos pelo estado, esse tipo de coprodução é substituível pelo esforço do órgão público e, portanto, opcional (Alford, 2015) por parte da instituição, todavia reconhecida como valiosa pelos gestores.

Já a participação dos familiares nas tomadas de decisão das escolas - Coprodução Política - é recorrentemente citada na legislação federal brasileira e do distrito federal Constituição Federal, LDB, Lei do Fundeb, entre outras. Dentre os dez gestores escolares entrevistados, nove citaram esse tipo de coprodução, oito deles com exemplos de órgãos internos à escola com responsabilidade de aprovar suas finanças e com participação obrigatória da família. O entrevistado G.E.7, que não citou esse tipo de coprodução, explicou que existe o conselho escolar, porém ao longo dos últimos anos, uma vez que os alunos cujos familiares engajados no órgão foram saindo da escola, a participação da família no conselho cessou.

Foi apresentada ainda a participação em decisões estratégicas da escola, por meio da participação na assembleia geral e na aprovação do planejamento anual. Nesses fóruns são aprovados os Projetos Políticos Pedagógicos das escolas e com eles todas as diretrizes que guiarão a equipe de gestão.

A coprodução política (Pestoff, 2006) tem na sua essência o caráter coletivo, uma vez que os familiares elegem seus representantes, que por sua vez dão voz aos usuários nas 
decisões escolares; bem como voluntário (Alford, 2009) uma vez que não há quaisquer ônus aplicados aos familiares que não participarem. Já do ponto de vista da escola, a coprodução política não é opcional, uma vez que está na legislação que as finanças escolares devem ser aprovadas por unidade executora com representação da comunidade escolar, sob pena de não aprovação das contas ou transferências de recursos.

Nota-se que ao descrever as formas de coprodução da educação pública um dos poucos pontos de unanimidade é que a Coprodução Pedagógica é a mais importante para a escola. Ela tem um caráter fundamental e insubstituível, nas palavras do entrevistado G.E.8: “a escola sozinha não dá conta de trabalhar com os alunos e dar o máximo de aprendizagem”.

A coprodução pedagógica se evidenciou de diversas formas. Por meio do diálogo e planejamento junto aos professores, nas formas de incentivar o aprendizado no aluno (reunião de pais, conversas a parte sobre o aprendizado sob convocação, bem como a comunicação pela agenda escolar). Por meio da demonstração de interesse e até cobrança pelo aprendizado, junto ao aluno - perguntando como está a escola - e junto ao professor - cobrando o desenvolvimento dos alunos. Também por meio de atividades que intensificam o aprendizado em casa, como elaboração das tarefas junto ao aluno e lendo e incentivando a leitura. Ainda por meio de atividades na própria escola, na participação nos projetos pedagógicos executados pelos alunos, em especial na sua culminância - momento no fim de cada projeto pedagógico feito ao longo do ano no qual os resultados destes são apresentados pelos alunos - e nas atividades mais ordinárias da escola em contexto onde isso melhora o comportamento do aluno e assim seu aprendizado.

A coprodução pedagógica demonstra caráter predominantemente individual. Quanto à voluntariedade, a despeito de a legislação federal colocar a educação como dever da família (Constituição Federal e LDB), é notável que apenas parcela dos familiares coproduzem pedagogicamente. Vários gestores escolares citaram como recorrentes famílias que veem a escola como "uma creche, que só serve para cuidar da criança enquanto o pai trabalha, e não um lugar onde ela vai aprender" (G.E. 1). Apesar de parcela relevante das famílias não cumprirem plenamente este tipo de coprodução, ela não possui caráter opcional. A coprodução pedagógica é um imperativo para o desenvolvimento dos alunos - fato evidenciado por todos os gestores escolares que citaram tal forma de coprodução e enfatizaram sua relevância.

Ao analisar o serviço público educação, sob a perspectiva da escolha do prestador de serviço em coproduzir proposta por Alford (2015), deve-se levar em consideração a substitutibilidade da participação da família, ou seja, a capacidade da escola em substituir 
aquela atividade, como no provimento de infraestrutura escolar, bem como a interdependência, ou seja, a existência de atividades que necessariamente precisem do prestador e do usuário, como a reunião de pais. Dentre as categorias de coprodução identificadas, a que apresentou menor grau de substitutibilidade foi a coprodução básica, ou seja, aquelas atividades sob responsabilidade da família que são premissas para que a educação ocorra. Nas entrevistas com gestores escolares, os exemplos citados desse tipo de coprodução foram o amparo à saúde física e psicológica do aluno por meio de exames, laudos e remédios; a execução da logística necessária para o aluno estar na escola sempre que necessário (levar e buscar); o desenvolvimento no aluno de um comportamento que permita que o mesmo seja educado sem atrapalhar a educação dos demais, com exemplos de valores e cidadania; organizar os materiais escolares (como livros e uniformes) e auxiliar os alunos a utilizá-los.

Essa forma de coprodução tem caráter amplamente individual, uma vez que esse suporte básico se dá na relação entre família e aluno. Por outro lado, essa coprodução, uma vez que prevista em lei, é fortemente involuntária. Dentre os motivos pelos quais os gestores escolares lançam mão de estratégias de Exposição e Acionamento de Mecanismos Legais, todos se relacionam à negligência familiar ao participar nesta forma de coprodução.

É notável que na pesquisa que muniu o framework de formas de coprodução proposto por Pestoff (2006) não foram identificadas formas de coprodução desta categoria, todavia nesta pesquisa, seis dos dez gestores escolares apontaram exemplos. Isso indica a necessidade de checar, em estudos posteriores, se a diferença se deve ao nível de desenvolvimento dos países.

Por último, também se identificou uma forma de coprodução que não se encaixou nas categorias anteriores, na qual os familiares dos alunos se juntam em grupos para influenciar órgãos da educação em prol das necessidades escolares. A observação da pesquisa foi de um grupo de mães, que por meio de contatos com o Governo do Distrito Federal conseguiu explicitar a necessidade de mudanças na forma como o transporte escolar funcionava na escola, e tais necessidades foram atendidas. Tal forma de coprodução se enquadrada na categoria coprodução pela influência das famílias - não identificada na literatura de coprodução de serviços públicos, cabendo futuras investigações mais aprofundadas sobre o fenômeno.

No questionário aplicado junto a familiares de alunos foram tratadas seis formas de coprodução, representando as quatro categorias propostas por Pestoff (2006), como observado 
na Tabela 1 - Questão: A quais das atividades a seguir você se dedica voluntariamente para ajudar a tornar a educação melhor? $(\mathrm{N}=269)$

Tabela 1 - Questão: A quais das atividades a seguir você se dedica voluntariamente para ajudar a tornar a educação melhor? ( $\mathrm{N}=269)$

\begin{tabular}{llc}
\hline TIPO DE COPRODUÇÃO & FORMA DE COPRODUÇÃo & OCORRÊNCIAS \\
(PESTOFF, 2006) & & 68 \\
\hline COPRODUÇÃO ECONÔMICA & $\begin{array}{l}\text { Executar atividades de desenvolvimento da escola } \\
\text { (trabalhar em reformas, eventos) }\end{array}$ & 81 \\
\cline { 2 - 3 } & Doar recursos financeiros ou de outros tipos (materiais & 201 \\
\hline COPRODUÇÃO SOCIAL & etc.) & 205 \\
(N=201) & Participar de festas e eventos promovidos pela escola & 117 \\
\hline COPRODUÇÃO PEDAGÓGICA & Apoiar na elaboração das tarefas de casa & 103 \\
\cline { 2 - 3 }$(\mathrm{N}=230)$ & Pedir conselhos da escola sobre como auxiliar o filho & \\
\hline COPRODUÇÃO POLÍTICA & Participar do Conselho escolar ou Associação de Pais e & \\
$(\mathrm{N}=103)$ & Professores & \\
\hline
\end{tabular}

Nota-se que todas as formas de coprodução foram observadas em pelo menos 68 ocorrências, ou $25 \%$ dos familiares. As mais frequentes foram o Apoio na elaboração das tarefas de casa (coprodução pedagógica) e Participar de festas e eventos promovidos pela escola (coprodução social), ambas com respostas positivas em cerca de três quartos das observações.

$\mathrm{Na}$ Tabela 2 - Caraterização da coprodução entre a família e a escola $(\mathbf{N}=\mathbf{2 6 9})$. são apresentados os resultados da coprodução entre a família e a escola agrupadas pelo tipo de coprodução - individual e coletiva. Quanto à coprodução coletiva, cerca de 3 em cada 4 familiares $(74.7 \%)$ referiu participar de festas e eventos promovidos pela escola. Uma menor percentagem participa do Conselho escolar ou Associação de Pais e Professores (38.3\%) ou executa atividades de desenvolvimento da escola (trabalhar em reformas, eventos) (25.3\%). Já na coprodução individual, cerca de 3 em cada 4 familiares (76.2\%) apoiam o estudante na elaboração das tarefas de casa. Uma menor percentagem pede conselhos da escola sobre como auxiliar o tutelado $(43,5 \%)$ ou doa recursos financeiros ou de outros tipos (materiais etc.) (30.1\%).

Tabela 2 - Caraterização da coprodução entre a família e a escola $(\mathrm{N}=269)$.

\begin{tabular}{lll}
\hline VARIÁVEIS & n & $\%$ \\
\hline
\end{tabular}




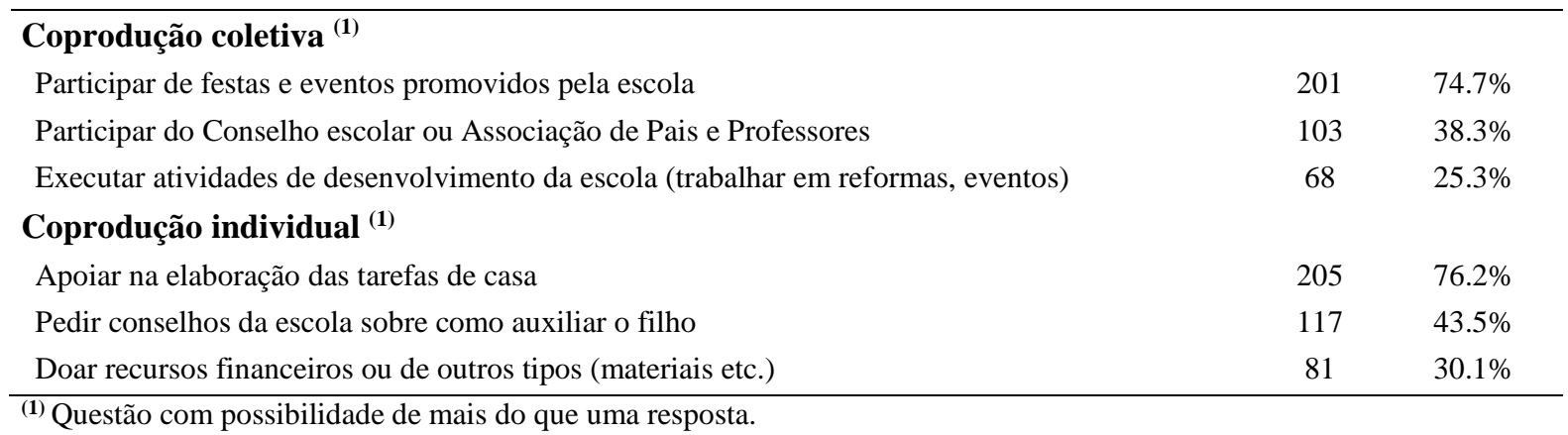

Para avaliar a coprodução coletiva, a coprodução individual e a coprodução como um todo, e com o objetivo de comparar as duas formas de coprodução, foram criadas variáveis quantitativas que representam o número de formas de coprodução em que os familiares de alunos participaram. Estas variáveis podem variar de zero (não refere nenhuma forma de coprodução) a três (refere as três formas de coprodução), no caso da coprodução individual e coletiva. No caso da coprodução total, a variável pode variar de zero a seis (refere as 6 formas de coprodução).

Em média, cada familiar de aluno referiu 2.9 dos seis itens de coprodução apresentados. Apenas três (1.1\%) não referiram nenhum, sendo mais frequentes os que se referiram a dois $(30.1 \%)$ ou três $(28.3 \%)$ itens relativos à coprodução. Quanto à coprodução coletiva, predominaram os que referiram a um item (49.4\%) ou dois itens (29.4\%), sendo que 11.2\% não referiram a nenhuma das 3 atividades. Em média, cada familiar de aluno se referiu a 1.4 das três formas de coprodução coletiva. Relativamente à coprodução individual, predominaram também os familiares que referiram a um item (41.3\%) ou dois itens (34.2\%), sendo que também $11.2 \%$ não se referiram a nenhuma das 3 atividades. Em média, cada familiar de aluno se referiu a 1.5 das três formas de coprodução individual, conforme apresentado na Tabela 3 - Caraterização e comparação da coprodução coletiva e individual entre a família e a escola $(\mathrm{N}=269)$.

Tabela 3 - Caraterização e comparação da coprodução coletiva e individual entre a família e a escola $(\mathrm{N}=269)$.

\begin{tabular}{cccc}
\hline $\begin{array}{l}\text { Número de formas de } \\
\text { coprodução }\end{array}$ & $\begin{array}{c}\text { Coprodução total } \\
(\mathrm{N}=169)\end{array}$ & $\begin{array}{c}\text { Coprodução coletiva } \\
(\mathrm{N}=169)\end{array}$ & $\begin{array}{c}\text { Coprodução individual } \\
(\mathrm{N}=169)\end{array}$ \\
\hline Zero & $3(1.1 \%)$ & $30(11.2 \%)$ & $30(11.2 \%)$ \\
$\mathbf{1}$ & $32(11.9 \%)$ & $133(49.4 \%)$ & $111(41.3 \%)$ \\
$\mathbf{2}$ & $81(30.1 \%)$ & $79(29.4 \%)$ & $92(34.2 \%)$ \\
$\mathbf{3}$ & $76(28.3 \%)$ & $27(10.0 \%)$ & $36(13.4 \%)$ \\
$\mathbf{4}$ & $45(16.7 \%)$ & - & - \\
$\mathbf{5}$ & $19(7.1 \%)$ & - & - \\
$\mathbf{6}$ & $13(4.8 \%)$ & - & $\mathbf{1 . 5 ( \mathbf { 0 . 9 } )}$ \\
\hline Média (desvio-padrão) & $\mathbf{2 . 9 ( 1 . 3 )}$ & $\mathbf{1 . 4 ( 0 . 8 )}$ & \\
\hline
\end{tabular}

Teste do Wilcoxon para comparação da coprodução coletiva e individual: $p=0.080$. 
O Teste de Wilcoxon para a comparação da distribuição da coprodução coletiva com a coprodução individual mostrou que não existem diferenças significativas entre as duas variáveis $(p=0.080)$.

\subsection{Políticas de incentivo à colaboração de familiares pelos governos federal e distrital}

Devido à importância da participação dos familiares da educação pública, como apresentado por Christophe et al. (2015), o esforço do estado em garanti-la pode ser identificado desde os documentos fundamentais da federação, como na Constituição de 1988, até o dia a dia das escolas, em ações empreendidas pelos diretores das escolas públicas.

A Constituição Federal de 1988 tem seu terceiro capítulo dedicado à educação, esporte e cultura, definindo no artigo 205 que a educação é de responsabilidade compartilhada entre o estado e a família, explicitando a importância da coprodução deste serviço público pelo usuário: "a educação, direito de todos e dever do Estado e da família, será promovida e incentivada com a colaboração da sociedade, visando ao pleno desenvolvimento da pessoa, seu preparo para o exercício da cidadania e sua qualificação para o trabalho". Apesar de explicitar a coprodução como diretriz da educação, pelo caráter de política fundamental, a constituição não chega a explicitar incentivos à coprodução. O documento também explicita a gestão democrática como básica na educação no seu artigo 206, em que o sexto princípio básico da educação é a "gestão democrática do ensino público, na forma da lei”. O documento não descreve o que seria a "gestão democrática" no contexto da educação, todavia isso vem a ser apresentado na Lei federal $n^{\circ}$ 9.394, conhecida como Lei de Diretrizes e Bases da Educação (LDB).

A LDB reafirma a Constituição ao apresentar a educação como "dever da família e do estado" no Ar.t $2^{\circ}$, e no Art. $14^{\circ}$ explicita o que é entendido por gestão democrática na legislação brasileira:

Art. 14. Os sistemas de ensino definirão as normas da gestão democrática do ensino público na educação básica, de acordo com as suas peculiaridades e conforme os seguintes princípios:

I - participação dos profissionais da educação na elaboração do projeto pedagógico da escola;

II - participação das comunidades escolar e local em conselhos escolares ou equivalentes. 
Dessa forma, ao colocar a participação da comunidade local nos conselhos, a legislação federal abre caminho para a participação da comunidade na escola, apesar de não explicitar como deve se dar essa participação, nem quem são os atores que são considerados na comunidade. Os documentos federais que regulamentam o que a LDB coloca como papel dos "conselhos escolares ou equivalente", bem como a forma de participação é a Lei $\mathrm{n}^{\circ} 11.947$, de 16 de junho de 2009, que dispõe sobre o Programa Dinheiro Direto na Escola, bem como o Manual de orientação para constituição de unidade executora própria. Este manual apresenta que:

\begin{abstract}
Independentemente da denominação que a escola e sua comunidade escolham, a ideia é a participação de todos na sua constituição e gestão pedagógica, administrativa e financeira. O importante é que ao constituir sua Unidade Executora, a escola congregue pais, alunos, funcionários, professores e membros da comunidade, de modo que esses segmentos sejam representados em sua composição.
\end{abstract}

Dessa forma, fica explícita a participação de familiares, nesse texto representados pela palavra "pais", como parte da comunidade e assim dos conselhos das escolas. Quanto aos papéis desses conselhos, o Manual aponta que a Unidade Executora tem como atribuições:

1. administrar recursos transferidos por órgãos federais, estaduais, distritais e municipais;

2. gerir recursos advindos de doações da comunidade e de entidades privadas;

3. Controlar recursos provenientes da promoção de campanhas escolares e de outras fontes;

4. Fomentar as atividades pedagógicas, a manutenção e conservação física de equipamentos e a aquisição de materiais necessários ao funcionamento da escola;

5. prestar contas dos recursos repassados, arrecadados e doados

Das formas de coprodução apresentadas por Pestoff (2006) - ficam explícitas nessa lista de atribuições a coprodução política, uma vez que os conselhos têm como atribuições administrar, gerir e controlar recursos; pedagógica, identificada na atribuição de fomentar atividades pedagógicas; e financeira, dado que os conselhos administram recursos provenientes das comunidades e campanhas escolares. 
A Lei de Diretrizes e Bases da Educação apresenta ainda no artigo 12 que as escolas têm a incumbência de "articular-se com as famílias e a comunidade, criando processos de integração da sociedade com a escola", e no Art. 13 que os docentes têm a incumbência de “colaborar com as atividades de articulação da escola com as famílias e a comunidade". Percebe-se nesse trecho da LDB que, além de colocar como dever de a família coproduzir, a lei define como dever da escola, gestores e diretores, a busca pela prestação do serviço em coprodução.

Ainda no nível federal, foi aprovada em 1990, dois anos depois da promulgação Constituição de 1988, a Lei no 8.069, também conhecida como Estatuto da Criança e do Adolescente (ECA), com o propósito de regulamentar os direitos das crianças e adolescentes no território brasileiro. O ECA dispõe sobre a participação da família na educação quando apresenta no Art.53 que "é direito dos pais ou responsáveis ter ciência do processo pedagógico, bem como participar da definição das propostas educacionais". Aqui fica claro o papel da escola de informar sobre o processo pedagógico, ação que Bovaird apresenta como um incentivo à coprodução, ao defender que usuários bem informados coproduzem mais, bem como, o papel de participar da definição das propostas educacionais, também apresentado por Bovaird como um incentivo, uma vez que usuários que participam das definições do serviço se dedicam mais ao seu sucesso.

O Estatuto da Criança e do Adolescente traz ainda como obrigação dos pais ou responsáveis, no Art.55, "matricular seus filhos ou pupilos na rede regular de ensino". Percebe-se que o estatuto explicita uma ação na qual a família é insubstituível pelo estado, ou seja, apenas a família pode ir à escola realizar a matrícula. Alford (2015) aponta a existência desse papel insubstituível na prestação do serviço como uma variável (substitutibilidade) que indica a coprodução.

Apesar de colocar a coprodução como obrigatória, o ECA não explicita ônus algum a quem descumprir a ação citada. Lista apenas, enquanto dever do gestor escolar, no Art. 56, comunicar ao Conselho Tutelar os "casos de: I - maus-tratos envolvendo seus alunos; II reiteração de faltas injustificadas e de evasão escolar, esgotados os recursos escolares; III elevados níveis de repetência." Nota-se aqui mais um papel na promoção da educação que apenas a família pode exercer - o que Alford (2015) apresenta como uma ação insubstituível, o de garantir a frequência do aluno, evitando a "reiteração de faltas injustificadas e evasão escolar". Colocando para o gestor escolar a responsabilidade de comunicar o conselho tutelar, o ECA cria um contexto onde a tutela do pai ou responsável sobre criança ou adolescente fica 
ameaçada no caso de negligência em coproduzir a educação, ficando claro um caráter involuntário da coprodução.

Foram identificados também mecanismos de incentivo do governo à coprodução, que premiam os familiares que garantirem a presença do aluno na escola. O Programa Bolsa Família (que substituiu em 2004 o Bolsa Escola, com formato semelhante) é um programa de transferência de renda sob determinadas condições, sendo uma delas a frequência escolar. No Art. $3^{\circ}$ da Lei $n^{\circ} 11.692$ de 2008 , que trata do programa, é apontado que "a frequência escolar relacionada ao benefício previsto no inciso III do caput do art. $2^{\circ}$ desta Lei considerará $75 \%$ (setenta e cinco por cento) de frequência". Assim o benefício da transferência de renda é dado aos pais ou responsáveis que garantirem a presença dos alunos.

Nesse contexto, a despeito de ser um programa social, no art. $3^{\circ}$ da Lei $n^{\circ} 10.836$, de 2004 (alterado pelo Decreto $n^{\circ}$ 6.917, de 2009) é apresentado que o Ministério da Educação é responsável pelo "acompanhamento e fiscalização do cumprimento das condicionalidades vinculadas ao Programa Bolsa Família" no que diz respeito "à frequência mínima ... da carga horária escolar mensal, em estabelecimentos de ensino regular, de crianças e adolescentes de seis a quinze anos".

Ainda no âmbito federal, foi identificada uma política que visa a aproximação das famílias à escola por meio da utilização do espaço da escola para a utilização pela comunidade. Trata-se do Programa Escola Aberta, como apresentado no Manual De Orientação para Constituição de Unidade Executora Própria. A ideia do programa é que "realizando ações de educação não-formal, desenvolvendo atividades de arte, lazer, cultura, esporte, ensino complementar e formação inicial para o trabalho e para a geração de renda, o Programa Escola Aberta promove espaços para o exercício de cidadania, para a organização comunitária e para a aproximação entre comunidade e escola com o reconhecimento e respeito aos diferentes saberes". No programa, o Governo Federal provê recursos para as escolas reformarem a estrutura de quadra poliesportiva e, como contrapartida, é demandada a realização das ações citadas acima. Nesse programa fica explícito o que Pestoff (2006) colocou como coprodução social da educação, na qual o familiar participa de eventos culturais da escola, e, por meio interação com demais membros da comunidade escolar, favorece a educação.

Outra política federal que visa incentivar a coprodução da educação é o Plano de Mobilização Social pela Educação, "resultado do chamado do Ministério da Educação à sociedade para um trabalho voluntário de mobilização das famílias e da comunidade pela 
melhoria da qualidade da educação brasileira” (Relatório de atividades 2008/2011, MEC, 2011).

\begin{abstract}
A base do Plano de Mobilização pode ser sintetizada na educação como um direito e um dever das famílias:

a) todas as famílias e responsáveis pelas crianças e jovens têm o direito de reivindicar que a escola dê uma educação de qualidade para todos os alunos. Podem e devem cobrar providências, medidas e ações para que isso ocorra.

b) todas as famílias e responsáveis pelas crianças e jovens têm o dever de ajudar a escola em casa, criando disciplina e rotina de estudos.
\end{abstract}

Dentre as ações listadas no relatório, estão o diálogo “com os públicos de interesse sobre a importância da educação", tratando do "papel de cada um como protagonista dessa agenda com amigos, vizinhos, parentes, associação de moradores, entre outros". Um dos objetivos citados é "falar sobre o papel da família na educação dos filhos". Outra ação descrita no relatório são as campanhas de conscientização, trabalho voluntário que aproxime escola e comunidade, convidando para serem voluntárias da mobilização. Apesar de o documento não relatar caso concreto de trabalho voluntário que aproxime a escola e comunidade, o texto mostra uma indicação de incentivo ao apoio da comunidade à escola, ou seja, à coprodução.

Ainda dentre as políticas federais foi identificado um Projeto de Lei - em trâmite no Senado Federal - cujo objetivo é dispor sobre "o acompanhamento pedagógico de crianças e adolescentes na escola pelos pais ou responsáveis legais". O texto inclui alterações na LDB, sugerindo um artigo que obriga as escolas a realizar duas reuniões por semestre para acompanhamento dos familiares, e sugerindo um artigo na CLT, que dá direito a empregados de até oito horas por semestre, "acompanhar os dependentes legais na escola, mediante declaração de comparecimento emitida por instituição de ensino vinculada ao Ministério da Educação".

Assim como o projeto, entretanto em nível distrital há uma lei - $\mathrm{n}^{\circ} 449$, de 17 de maio de 1993, que institui o "Abono de Ponto Bimestral" a falta dos servidores públicos do Governo do Distrito federal para ir à reunião de pais e mestre, conforme apresentado no seu Art. $1^{\circ}$. A lei concede o abono a "pais e responsáveis, funcionários da Administração Direta, Indireta, Autárquica e Fundacional do Distrito Federal, bem como do Poder Legislativo”. É interessante observar nesta lei o estado incentiva a participação da família.ao retirar um potencial impedimento à coprodução, a citar, o ônus devido à ausência do familiar no trabalho. 
A lei 449 não é a única iniciativa de incentivo à coprodução empreendida pelo Governo do Distrito Federal, no Projeto Político Pedagógico (PPP) Professor Carlos Mota SEEDF, documento que objetiva planejar, orientar e construir diretrizes para a rede pública de ensino do Distrito Federal, fica explícita a necessidade de envolvimento da comunidade escolar. No documento é utilizado o termo "corresponsabilidade" para tratar do papel da comunidade - que abrange "o grupo das famílias e responsáveis pelos estudantes" - na gestão, atividades pedagógicas e aprendizagem.

O PPP traz ainda uma política que aborda a instrução dos familiares para melhor apoiar no processo de aprendizagem, a Orientação Educacional. Esse serviço visa a "que a partir da participação de todos na escola, que orientação educacional consiga, junto com professores, estudantes, família e demais profissionais da educação, fortalecer o compromisso com uma educação transformadora”.

Em consonância com a legislação federal, em especial a Constituição e o Estatuto da Criança e do Adolescente, o Projeto Político Pedagógico traz diretrizes claras para as escolas agirem em contextos de negligência familiar frente à educação do aluno. "Sempre que o Estado toma conhecimento de que esses direitos estão ameaçados ou violados por falta, omissão ou abuso dos pais ou responsáveis, cabe a este, por meio das instâncias competentes".

Podemos verificar dentre as políticas identificadas quatro categorias: as Participativas, que garantem espaço nas decisões escolares para os familiares, como a constituição federal e as leis de repasse de recursos para escolas; as Punitivas, que criam mecanismos geram ônus aos familiares que não cumprirem com seu papel na coprodução, como por exemplo, a perda da tutela do aluno. São exemplos destas a Lei de Diretrizes e Bases da Educação e o Estatuto da Criança e do Adolescente; as instrutivas: mobilizam recursos para educar a família e torna-la mais apta a coproduzir, como o Plano de Mobilização Social pela Educação e o Serviço de Orientação Educacional; e as de Incentivo Indireto, como o bolsa família e a lei obriga as instituições a abonares as ausências dos familiares em dias de reunião de pais. 


\subsection{Ações das escola de Incentivo à coprodução da educação}

Dado a arcabouço de políticas promovidas pelo governo federal e distrital para incentivar a família a coproduzir a educação fundamental, cabe aos gestores das escolas implementá-las e julgar a necessidade de implementar estratégias complementares às políticas, ambas são apresentadas neste capítulo.

\subsubsection{Mecanismos formais das escolas de incentivo à coprodução da educação}

Com o objetivo de entender os mecanismos formais de incentivo à coprodução, ou seja, aqueles que derivam das leis, perguntou-se por meio de entrevista: A escola possui mecanismos formais de incentivo à participação da família, como conselho escolar, associação de pais e professores etc.?

Foi identificada na literatura uma ação que se mostrou incentivadora da coprodução da educação pública: Ostrom (1996), ao buscar o entendimento de como as famílias coproduziam a educação na Nigéria, notou que houve uma queda no engajamento familiar em contextos onde o governo tomou decisões que mudaram a dinâmica educacional sem consulta aos colaboradores da escola e aos familiares. Por outro lado, identificou um caso onde a coprodução era muito profícua numa escola onde a associação de pais era ativa a décadas, sem interrupção. Ainda é possível observar esse mecanismo sob o ponto de vista de Pestoff (2006) que coloca como coprodução política aquela na qual os familiares se organizam, notam e participam de decisões relevantes para a escola. Thaler e Sunstein (2009) e John et al. (2009) argumentam que os órgãos públicos incentivam comportamentos construtivos ao serviço público a partir da criação de contextos de debate entre grupos de cidadão relacionados na decisão, uma vez que as pessoas tendem a considerar opiniões de pares. Para esse mecanismo de incentivo, foi delineada a categoria "Gestão Democrática - participação nas decisões da escola".

Ainda no trabalho de Ostrom (1996), mas também no de Bitner et al. (1997) e Dafar et al. (2013), foi identificado um efeito positivo do provimento extensivo de informação aos usuários em serviços públicos - em nenhum dos casos estudados pelos autores o provimento de informação estudado era na educação pública. Os autores notaram que, uma vez detentores 
do conhecimento necessário para coproduzir, os usuários do serviço o faziam de forma mais intensa. Para esse perfil de estratégia, foi delineada a categoria “Orientação aos familiares".

No Quadro 11 - Registro da inclusão e confirmação de categorias de mecanismos

formais de coprodução é apresentado um resumo da ocorrência das categorias identificadas ao longo das 10 entrevistas.

Quadro 11 - Registro da inclusão e confirmação de categorias de mecanismos formais de coprodução

\begin{tabular}{|c|c|c|}
\hline \multirow{3}{*}{$\begin{array}{l}\text { ENTREVISTA } \\
1\end{array}$} & INCLUIU & CONFIRMOU \\
\hline & & 1. Orientação aos familiares \\
\hline & & $\begin{array}{l}\text { 2.Gestão Democrática permitindo a } \\
\text { participação nas decisões da escola }\end{array}$ \\
\hline \multirow{3}{*}{$\begin{array}{l}\text { ENTREVISTA } \\
2\end{array}$} & INCLUIU & CONFIRMOU \\
\hline & & 1. Orientação aos familiares \\
\hline & & $\begin{array}{l}\text { 2.Gestão Democrática permitindo a } \\
\text { participação nas decisões da escola }\end{array}$ \\
\hline \multirow[b]{2}{*}{$\begin{array}{l}\text { ENTREVISTA } \\
3\end{array}$} & INCLUIU & CONFIRMOU \\
\hline & $\begin{array}{l}\text { 3. Consulta à opinião dos familiares } \\
\text { quanto às atividades da escola }\end{array}$ & $\begin{array}{l}\text { 1. Orientação aos familiares } \\
\text { 2.Gestão Democrática permitindo a } \\
\text { participação nas decisões da escola }\end{array}$ \\
\hline \multirow[b]{2}{*}{$\begin{array}{l}\text { ENTREVISTA } \\
\quad 4\end{array}$} & INCLUIU & CONFIRMOU \\
\hline & & $\begin{array}{l}\text { 1. Orientação aos familiares } \\
\text { 2.Gestão Democrática permitindo a } \\
\text { participação nas decisões da escola }\end{array}$ \\
\hline \multirow[b]{2}{*}{$\begin{array}{c}\text { ENTREVISTA } \\
5\end{array}$} & INCLUIU & CONFIRMOU \\
\hline & & $\begin{array}{l}\text { 1. Orientação aos familiares } \\
\text { 2.Gestão Democrática permitindo a } \\
\text { participação nas decisões da escola }\end{array}$ \\
\hline \multirow{2}{*}{$\begin{array}{l}\text { ENTREVISTA } \\
6\end{array}$} & INCLUIU & CONFIRMOU \\
\hline & & $\begin{array}{l}\text { 2.Gestão Democrática permitindo a } \\
\text { participação nas decisões da escola }\end{array}$ \\
\hline \multirow[b]{2}{*}{$\begin{array}{l}\text { ENTREVISTA } \\
7\end{array}$} & INCLUIU & CONFIRMOU \\
\hline & & $\begin{array}{l}\text { 2.Gestão Democrática permitindo a } \\
\text { participação nas decisões da escola }\end{array}$ \\
\hline \multirow[b]{2}{*}{$\begin{array}{l}\text { ENTREVISTA } \\
8\end{array}$} & INCLUIU & CONFIRMOU \\
\hline & & $\begin{array}{l}\text { 2.Gestão Democrática permitindo a } \\
\text { participação nas decisões da escola }\end{array}$ \\
\hline \multirow{3}{*}{$\begin{array}{l}\text { ENTREVISTA } \\
9\end{array}$} & INCLUIU & CONFIRMOU \\
\hline & & $\begin{array}{l}\text { 1. Orientação aos familiares } \\
\text { 2.Gestão Democrática permitindo a } \\
\text { participação nas decisões da escola }\end{array}$ \\
\hline & & $\begin{array}{l}\text { 3. Consulta à opinião dos familiares quanto } \\
\text { às atividades da escola }\end{array}$ \\
\hline ENTREVISTA & INCLUIU & CONFIRMOU \\
\hline
\end{tabular}


O G.E. 1 citou como mecanismos formais de incentivo à participação da família a reunião de pais, o conselho escolar e a associação de pais e mestres. Quanto ao conselho escolar foi enfatizado pelo gestor que "o conselho passa por uma eleição e tem representantes da escola, ... como pais, num total de 7 pessoas". G.E.1 citou, ainda, como funções dos órgãos a tomada de decisões importantes para a escola, como os gastos e investimentos. Esses mecanismos - conselho escolar e associação de pais e mestres - dada sua semelhança quanto ao objetivo e forma, foram agrupados na categoria "Gestão Democrática - participação nas decisões da escola".

Ainda na entrevista com G.E.1 foi citada a reunião de pais, na qual os professores conversam à parte com cada familiar presente, contando como foi o bimestre do aluno e como este pode ser auxiliado pelo apoio dos pais e responsáveis. Esse mecanismo é condizente com o que Ostrom (1996), Bitner et al. (1997), Dafar et al. (2013) identificaram como um efeito positivo do provimento extensivo de informação aos usuários em serviços públicos, confirmando a categoria "Orientação aos familiares".

A segunda entrevista (G.E.2) confirmou as duas categorias. Nela o gestor escolar citou como formas de orientação a familiares as reuniões de pais e também o Serviço de Orientação Educacional, também citado no Projeto Político Pedagógico (PPP) Professor Carlos Mota - SEEDF. G.E.2 apresentou o serviço de apoio a alunos e professores, orientando a família sempre que necessário para recuperar deficiências no aprendizado. Em relação à categoria Gestão Democrática - participação nas decisões, o segundo entrevistado, além de citar o conselho escolar, apontou audiência pública prévia às eleições dos gestores escolares - diretor e vice-diretor - para que a família opinasse sobre as propostas dos candidatos.

A terceira entrevista trouxe as mesmas evidências da segunda para a categoria Orientação aos familiares, a reunião de pais e o Serviço de Orientação Educacional. Já em relação à Gestão democrática - participação nas decisões, G.E.3 citou o conselho escolar já tratado nas entrevistas anteriores, e acrescentou a abertura do conselho de classe à participação da família. Esse mecanismo formal de incentivo à participação da família se mostra interessante, pois além de permitir a coprodução política descrita por Pestoff (2006), dá abertura para a coprodução pedagógica citada pelo autor. 
Além de confirmar as duas primeiras categorias, a terceira entrevista trouxe dois diferentes mecanismos formais de incentivo à participação, o questionário "Como posso ajudar? ", aplicado anualmente, no qual os familiares indicam de que forma estariam dispostos a ajudar a escola, e o questionário de avaliação da escola e auto avaliação da família, aplicado bimestralmente, no qual a família avalia a escola e avalio o próprio trabalho. O primeiro questionário se mostra relevante, à medida que explicita o interesse da escola em ter o apoio da família. Já o segundo questionário, na visão de G.E.3, é interessante para gerar uma reflexão nos familiares e abrir espaço para correção de rumos. Dessa forma, se mostrou necessária a inclusão da categoria "consulta à opinião da família quanto às atividades da escola" como mais um mecanismo formal de incentivo.

É interessante notar que, à medida que a escola questiona os familiares quanto às respectivas opiniões, a escola já orienta a família sobre as melhores formas de ajudar na educação dos alunos, como apresentado no trecho a seguir.

O questionário começa nos avaliando, "como o senhor tem sido recebido na escola?", "quando o senhor procura a escola para resolver os seus problemas, tem sido resolvido?", "o senhor tem sido bem atendido? "... E em meados dos questionários, começa a parte deles - familiares -, até de organização de mochila a gente fala, "o senhor tem acompanhado a organização da mochila, dos materiais da criança? ", "tem assinado a agenda todos os dias, semanalmente, eventualmente? ". A gente usa essas palavras com os familiares. (G.E.3)

As demais entrevistas apenas confirmaram as categorias oriundas das três primeiras.

No Quadro 10 são listados os mecanismos identificados para cada categoria:

Quadro 12 - Relação de categorias e exemplos observados de mecanismos formais de coprodução

\begin{tabular}{|c|c|c|c|}
\hline CATEGORIAS & $\begin{array}{l}\text { 1. Orientação aos } \\
\text { familiares }\end{array}$ & $\begin{array}{l}\text { 2.Gestão Democrática } \\
\text { permitindo a participação nas } \\
\text { decisões da escola }\end{array}$ & $\begin{array}{l}\text { 3. Consulta à opinião dos } \\
\text { familiares quanto às atividades } \\
\text { da escola }\end{array}$ \\
\hline $\begin{array}{l}\text { EXEMPLOS } \\
\text { IDENTIFICADOS }\end{array}$ & $\begin{array}{l}\text { Reuniões de pais } \\
\text { SOE - serviço de } \\
\text { orientação } \\
\text { educacional }\end{array}$ & $\begin{array}{l}\text { Conselho escolar (recursos de } \\
\text { órgãos públicos) } \\
\text { Associação de pais e mestres } \\
\text { (recursos arrecadados na escola) } \\
\text { Audiência Pública Eleição } \\
\text { Caixa escolar } \\
\text { Assembleia Geral } \\
\text { Abertura do conselho de classe }\end{array}$ & $\begin{array}{l}\text { Questionário - como posso } \\
\text { ajudar } \\
\text { Questionário de avaliação da } \\
\text { escola e auto avaliação da } \\
\text { família }\end{array}$ \\
\hline
\end{tabular}

Dessa forma, com a saturação teórica ocorrendo na terceira entrevista, quando "nenhuma nova informação ou nenhum novo tema foi registrado" (Thiry-Cherques, 2009), 
atingiu-se o ponto de saturação. Foram identificadas três categorias com a análise a posteriori, a citar:

1. Orientação aos familiares

A categoria Orientação aos familiares surgiu a priori devido à identificação de Ostrom (1996), Bitner et al. (1997) e Dafar et al. (2013), do efeito positivo do provimento extensivo de informação aos usuários em serviços públicos. Ela foi confirmada em seis das dez entrevistas realizadas, em especial por meio das Reuniões de pais, o principal canal de comunicação formal entre escola e família segundo os gestores escolares, e o SOE - Serviço de orientação educacional - política pública do Governo do Distrito Federal para orientar os principais atores envolvidos na educação - professor, alunos e família.

\section{Gestão democrática - participação nas decisões}

A categoria surgiu a priori a partir do estudo de Ostrom (1996) e foi confirmada em todas as entrevistas realizadas. Nota-se que além de ter importância amplamente reconhecida dentre os gestores escolares, tal mecanismo de incentivo à coprodução é exaustivamente regulamentado, sendo abordado desde a Constituição Federal de 1988, passando pela Lei de Diretrizes e Bases da Educação e também nas leis referentes a repasses de recursos federais para as escolas.

3. Consulta à opinião da família quanto às atividades da escola.

A única categoria identificada $a$ posteriori que não havia sido delineada a priori foi a consulta à opinião da família. Tal categoria foi identificada em duas entrevistas, na terceira e na nona, com observações relativas a questionários que abordam os familiares sobre formas dos mesmos ajudarem a escola, bem como sobre a satisfação destes com o desempenho da instituição e o próprio desempenho no apoio ao aprendizado dos alunos.

\subsubsection{Estratégias das escolas para o incentivo à coprodução da educação}

Além dos mecanismos formais utilizados pelas escolas para incentivar a participação dos familiares na educação, verificaram-se também estratégias informais. A literatura de coprodução de serviços públicos traz como estratégia de incentivo a criação de sanções aos usuários que não cumprirem seu papel. Alford (2009) identificou a existência de categoria de 
usuários de serviços públicos que seriam os obrigados a coproduzir, apesar de não citar casos específicos da educação. No contexto desta estratégia, o usuário do serviço não necessariamente receberia um valor em serviço ou mercadorias, mas sim estaria suscetível a sofrer ônus do órgão público responsável pela prestação do serviço. Para essa estratégia foi delineada a categoria "Exposição e acionamento de mecanismos legais".

Outra forma de incentivo foi identificada por Ostrom (1996), o "Provimento de Informações", todavia também não identificando na pesquisa casos na educação. A autora cita a importância do amplo provimento de informação aos cidadãos, bem como da ajuda na mediação do diálogo que levou às tomadas de decisão. Thaler e Sunstein (2009) trazem uma forma de incentivo semelhante à exposta por Ostrom (1996), que se refere ao provimento de informação. Os autores levantaram que os órgãos públicos podem identificar os possíveis erros dos usuários dos serviços e estabelecer mecanismos que informem o usuário, prevenindo repetições desses erros.

Para a verificação da aderência dessas categorias ao contexto da educação pública, bem como identificação de quaisquer categorias pertinentes, nas entrevistas com gestores escolares, estes foram questionados sobre quais eram as estratégias (ou formas) de incentivo à coprodução.

O entrevistado gestor escolar G.E.1 apresentou quatro estratégias da escola sob sua gestão para incentivar a participação das famílias: conversas entre os colaboradores da escola, professores e equipe de gestão e a família, a promoção de eventos e festas, os comunicados para as famílias feitos pelas agendas dos estudantes e a explicação da legislação que coloca como dever dos responsáveis a educação (ECA, LDB e Constituição Federal). Segundo o gestor, as conversas promovidas pelos colaboradores se mostram importantes, pois criam um canal de troca com a família, tornando os pais mais abertos às informações que a escola precise passar. Tal estratégia foi considerada parte da categoria "Diálogo entre colaboradores da escola e família". A segunda estratégia citada: promoção de festas e eventos, se mostra importante por gerar integração entre os familiares de diferentes alunos e criar um ambiente convidativo na escola, onde a família possa conviver com os colaboradores. Dessa forma, a estratégia foi denominada "Integração com toda a comunidade escolar". A terceira estratégia: comunicados enviados para os familiares pela agenda, foi colocada como essencial uma vez que é o principal meio de provimento de informações à todas as famílias, sendo categorizada como "Provimento de informação". Essa estratégia condiz com o que Ostrom (1996) identificou como profícuo para a prestação em outros serviços, confirmando a pertinência da categoria para a coprodução da educação pública. 
A última estratégia descrita foi a explicação da legislação, que coloca a educação como dever dos responsáveis (ECA, LDB e Constituição Federal), segundo o G.E.1, ao estarem cientes das obrigações e possíveis consequências de não contribuir com a educação, os familiares menos engajados tendem a participar mais da educação. Tal estratégia confirmou a pertinência da categoria "Exposição e acionamento de mecanismos legais".

$\mathrm{Na}$ segunda entrevista, o G.E.2 confirmou a categoria "Diálogo entre colaboradores da escola e família" ao relatar que a escola dedica três horas dos professores ao atendimento de familiares por semana, enfatizando a importância do contato personalizado entre o professor e o responsável pelo aluno. Também foi confirmada a categoria "Integração com toda a comunidade escolar" uma vez que a escola coloca a promoção de eventos e festas como um importante incentivo à participação da família. A categoria "Provimento de informação" foi confirmada uma vez que os comunicados por agenda foram considerados relevantes para a relação com familiares, assim como a utilização de mídias sociais, onde são postadas imagens, vídeos e textos com relatos do que os gestores da escola consideram geradores do interesse da comunidade. Por último, a segunda entrevista confirmou a categoria “Exposição e acionamento de mecanismos legais", uma vez que a direção relata acionar o Conselho tutelar sempre que considera que o diálogo com a família não surte efeito no engajamento.

O terceiro entrevistado, G.E.3, confirmou as quatro categorias previamente identificadas, "Diálogo entre colaboradores da escola e família" representado por conversas sempre que consideradas necessárias pelos professores, bem como conversas entre gestores e familiares na entrada e saída das aulas; a "Integração com toda a comunidade escolar" foi confirmada pela promoção de eventos e festas, shows de talentos, gincanas, abertura da escola para comemoração do aniversário dos alunos junto aos familiares, e o campeonato de futebol com os pais; já o "Provimento de informação" foi confirmado pelo relato do envios constantes de comunicados pela agenda dos alunos; e por último, a categoria "Exposição e acionamento de mecanismos legais" foi confirmada devido à citação de acionamento do Conselho tutelar como última medida de engajamento da família.

Ainda foram relatadas duas estratégias que não se enquadraram nas categorias até aqui definidas, se mostrando necessário o delineamento de uma nova. Segundo o entrevistado G.E.3, é dada na escola grande importância à autoestima do aluno, bem como à confiança dos familiares na sua capacidade de aprender, de forma que os professores são incentivados a elogiar o desenvolvimento dos alunos para os responsáveis, chegando a dar um certificado 
para os melhores alunos ao fim dos bimestres. Foi criada a categoria "Reconhecimento dos êxitos do estudante".

Nas demais entrevistas nenhuma categoria foi incluída. No Quadro 13 - Registro da inclusão e confirmação de categorias de estratégias de incentivo à coprodução está descrita a evolução do delineamento das categorias ao longo da coleta de dados, explicitando a saturação teórica na terceira entrevista. 
Quadro 13 - Registro da inclusão e confirmação de categorias de estratégias de incentivo à coprodução

\begin{tabular}{|c|c|c|}
\hline \multirow[b]{2}{*}{$\begin{array}{c}\text { ENTREVISTA } \\
1\end{array}$} & INCLUIU & CONFIRMOU \\
\hline & $\begin{array}{l}\text { 1. Diálogo entre colaboradores da } \\
\text { escola e família } \\
\text { 2. Integração com toda a comunidade } \\
\text { escolar }\end{array}$ & $\begin{array}{l}\text { 3. Provimento de informação } \\
\text { 4. Exposição e acionamento de mecanismos legais }\end{array}$ \\
\hline \multirow[b]{2}{*}{$\begin{array}{l}\text { ENTREVISTA } \\
2\end{array}$} & INCLUIU & CONFIRMOU \\
\hline & & $\begin{array}{l}\text { 1. Diálogo entre colaboradores da escola e família } \\
\text { 2. Integração com toda a comunidade escolar } \\
\text { 3. Provimento de informação } \\
\text { 4. Exposição e acionamento de mecanismos legais }\end{array}$ \\
\hline \multirow[b]{2}{*}{$\begin{array}{l}\text { ENTREVISTA } \\
3\end{array}$} & INCLUIU & CONFIRMOU \\
\hline & $\begin{array}{l}\text { 5. Reconhecimento dos êxitos do } \\
\text { estudante }\end{array}$ & $\begin{array}{l}\text { 1. Diálogo entre colaboradores da escola e família } \\
\text { 2. Integração com toda a comunidade escolar } \\
\text { 3. Provimento de informação } \\
\text { 4. Exposição e acionamento de mecanismos legais }\end{array}$ \\
\hline \multirow[b]{2}{*}{$\begin{array}{l}\text { ENTREVISTA } \\
4\end{array}$} & INCLUIU & CONFIRMOU \\
\hline & & $\begin{array}{l}\text { 1. Diálogo entre colaboradores da escola e família } \\
\text { 2. Integração com toda a comunidade escolar } \\
\text { 3. Provimento de informação } \\
\text { 4. Exposição e acionamento de mecanismos legais } \\
\text { 5. Reconhecimento dos êxitos do estudante }\end{array}$ \\
\hline \multirow[b]{2}{*}{$\begin{array}{l}\text { ENTREVISTA } \\
5\end{array}$} & INCLUIU & CONFIRMOU \\
\hline & & $\begin{array}{l}\text { 1. Diálogo entre colaboradores da escola e família } \\
\text { 2. Integração com toda a comunidade escolar } \\
\text { 3. Provimento de informação }\end{array}$ \\
\hline \multirow[b]{2}{*}{$\begin{array}{l}\text { ENTREVISTA } \\
6\end{array}$} & INCLUIU & CONFIRMOU \\
\hline & & $\begin{array}{l}\text { 1. Diálogo entre colaboradores da escola e família } \\
\text { 2. Integração com toda a comunidade escolar } \\
\text { 4. Exposição e acionamento de mecanismos legais }\end{array}$ \\
\hline \multirow[b]{2}{*}{$\begin{array}{l}\text { ENTREVISTA } \\
7\end{array}$} & INCLUIU & CONFIRMOU \\
\hline & & $\begin{array}{l}\text { 2. Integração com toda a comunidade escolar } \\
\text { 3. Provimento de informação } \\
\text { 4. Exposição e acionamento de mecanismos legais }\end{array}$ \\
\hline \multirow[b]{2}{*}{$\begin{array}{l}\text { ENTREVISTA } \\
8\end{array}$} & INCLUIU & CONFIRMOU \\
\hline & & $\begin{array}{l}\text { 2. Integração com toda a comunidade escolar } \\
\text { 3. Provimento de informação } \\
\text { 4. Exposição e acionamento de mecanismos legais }\end{array}$ \\
\hline \multirow{2}{*}{$\begin{array}{l}\text { ENTREVISTA } \\
\quad 9 \\
\end{array}$} & INCLUIU & CONFIRMOU \\
\hline & & 2. Integração com toda a comunidade escolar \\
\hline \multirow[b]{2}{*}{$\begin{array}{c}\text { ENTREVISTA } \\
10\end{array}$} & INCLUIU & CONFIRMOU \\
\hline & & $\begin{array}{l}\text { 1. Diálogo entre colaboradores da escola e família } \\
\text { 2. Integração com toda a comunidade escolar } \\
\text { 3. Provimento de informação }\end{array}$ \\
\hline
\end{tabular}




\section{No Quadro 14 - Relação de categorias e exemplos observados de estratégias de}

incentivo à de coprodução são listadas as estratégias identificadas junto aos gestores escolares.

Quadro 14 - Relação de categorias e exemplos observados de estratégias de incentivo à de coprodução

\begin{tabular}{|c|c|c|c|c|c|}
\hline Categoria & $\begin{array}{l}\text { 1. Diálogo } \\
\text { entre } \\
\text { colaboradores } \\
\text { da escola e } \\
\text { família }\end{array}$ & $\begin{array}{l}\text { 2. Integração } \\
\text { com toda a } \\
\text { comunidade } \\
\text { escolar }\end{array}$ & $\begin{array}{l}\text { 3. Provimento de } \\
\text { informação }\end{array}$ & $\begin{array}{l}\text { 4. Exposição e } \\
\text { acionamento de } \\
\text { mecanismos } \\
\text { legais }\end{array}$ & $\begin{array}{l}5 . \\
\text { Reconheciment } \\
\text { o dos êxitos do } \\
\text { estudante }\end{array}$ \\
\hline & $\begin{array}{l}\text { Conversa } \\
3 \text { horas dos } \\
\text { professores } \\
\text { dedicadas ao } \\
\text { atendimento } \\
\text { por semana } \\
\text { Diretores } \\
\text { recebem e } \\
\text { conversam } \\
\text { com pais na } \\
\text { entrada das } \\
\text { aulas } \\
\text { Acolhida na } \\
\text { entrada dos } \\
\text { alunos } \\
\text { Convocação } \\
\text { dos } \\
\text { professores }\end{array}$ & $\begin{array}{l}\text { Eventos: } \\
\text { festas, Bazar, } \\
\text { oficinas de } \\
\text { jogos, } \\
\text { Feira literária } \\
\text { Show de } \\
\text { talentos, } \\
\text { gincanas, } \\
\text { aniversário na } \\
\text { escola, futebol } \\
\text { com pais } \\
\text { Café da manhã } \\
\text { na reunião de } \\
\text { pais } \\
\text { Casar } \\
\text { atividades } \\
\text { com reunião } \\
\text { de pais } \\
\text { Desafio "Pai } \\
\text { vrs filho no O } \\
\text { que é o que é" } \\
\text { Projetos } \\
\text { pedagógicos } \\
\text { envolvendo } \\
\text { família } \\
\text { Dia de } \\
\text { provimento de } \\
\text { serviços para a } \\
\text { família - } \\
\text { oficinas de } \\
\text { gastronomia, } \\
\text { cabelereiro, } \\
\text { etc }\end{array}$ & $\begin{array}{l}\text { Comunicados por } \\
\text { agenda } \\
\text { Fanpage Facebook } \\
\text { Apresentação no } \\
\text { início do ano letivo } \\
\text { dos projetos } \\
\text { pedagógicos e de } \\
\text { orientações sobre } \\
\text { como a família deve } \\
\text { proceder } \\
\text { Carta de convocação } \\
\text { e ligação } \\
\text { Comunicação do } \\
\text { desempenho dos } \\
\text { alunos na reunião de } \\
\text { pais e sob } \\
\text { convocação dos } \\
\text { professores } \\
\text { Convocação aos pais } \\
\text { de alunos com } \\
\text { dificuldades } \\
\text { Parceria com outros } \\
\text { órgãos públicos para } \\
\text { palestras sobre } \\
\text { temas de interesse } \\
\text { das famílias (Detran, } \\
\text { posto de saúde, } \\
\text { universidade) } \\
\text { Encontros } \\
\text { promovidos pela } \\
\text { secretaria de } \\
\text { educação }\end{array}$ & $\begin{array}{l}\text { Explicar ECA, } \\
\text { LDB e } \\
\text { constituição } \\
\text { Conselho tutelar } \\
\text { Ministério } \\
\text { Público } \\
\text { Vara da Infância }\end{array}$ & $\begin{array}{l}\text { Conversa: } \\
\text { Retornos } \\
\text { positivos } \\
\text { quanto ao } \\
\text { desenvolviment } \\
\text { o dos alunos } \\
\text { Certificado de } \\
\text { aluno destaque } \\
\text { Recompensa } \\
\text { por } \\
\text { participação } \\
\text { com "escambo" } \\
\text { (moeda da } \\
\text { escola que pode } \\
\text { ser trocado por } \\
\text { lanches nas } \\
\text { festas e objetos } \\
\text { nos bazares) }\end{array}$ \\
\hline & & & $\begin{array}{l}\text { Ligar para as } \\
\text { famílias dos alunos } \\
\text { que faltam }\end{array}$ & & \\
\hline
\end{tabular}


Como observado no Quadro 14 - Relação de categorias e exemplos observados de estratégias de incentivo à de coprodução, feita a análise a posteriori, foram identificadas cinco categorias, discutidas nos cinco itens dispostos nos parágrafos seguintes.

1. Diálogo entre colaboradores da escola e família: A categoria não foi delineada $a$ priori, mas foi identificada em sete das dez entrevistas, com observações de estratégias como conversa entre os gestores ou professores e familiares - na entrada das aulas a partir de convocação realizar por professores, ou mesmo em ligações quando alunos são faltantes, dedicação de três horas por semana de cada professor da escola para o atendimento de familiares. Foi relatado pelos gestores escolares que o diálogo gera uma aproximação dos familiares em relação à escola, que sentem maior abertura e assim tendem a colaborar mais.

2. Integração com toda a comunidade escolar: com 100\% de ocorrência nas dez entrevistas realizadas, a integração com a comunidade escolar se mostrou como uma categoria de incentivo dominada pelas diversas escolas, que possuem várias estratégias nela enquadradas, como os eventos festivos (festa junina, dia das mães, natal), eventos diversos (bazar, oficinas de jogos, feira literária, show de talentos, gincanas, aniversário na escola, futebol com pais, dia de provimento de serviços para a família - oficinas de gastronomia, cabelereiro etc.), momentos de integração dentro de reuniões deliberativas (café da manhã na reunião de pais), envolvimento da comunidade nos projetos pedagógicos (em especial na culminância, momento no qual os resultados dos trabalhos dos alunos são apresentados). Apesar ter-se encontrado nenhum incentivo à coprodução de educação na literatura que se enquadre nessa categoria, nota-se a relação dela com a forma de coprodução Social, apresentada por Pestoff (2006), na qual familiares contribuem com a educação participando e prestigiando os momentos coletivos promovidos pela escola.

3. Provimento de informação: essa categoria, delineada a priori devido à contribuição de Ostrom (1996) e Thaler e Sunstein (2009) representa as estratégias da escola em munir os familiares com informação adequada e tempestiva para que a coprodução ocorra. Ao longo das entrevistas foram observados diversos exemplos desta forma de incentivo, algumas com o perfil de informação abordado por Ostrom (1996), na qual informações gerais sobre o serviço são providas, como os comunicados por agenda, a fanpage na rede social Facebook, a apresentação no início do ano letivo dos projetos pedagógicos (e da forma como deve proceder em relação a eles), eventos com palestra ministradas por outros órgãos públicos (Detran, posto de saúde, universidade) e pela própria secretaria de educação. Outros exemplos se mostraram mais alinhados com o perfil de informação trazido por Thaler e Sunstein (2009), na qual informações tempestivas sobre algo que não está dentro do que o órgão público 
considera ideal são passadas ao usuário, como envio de carta de convocação e ligação nos casos de necessidade eminente de participação dos familiares, comunicação do desempenho dos alunos na reunião de pais e sob convocação dos professores (em especial aos familiares de alunos com dificuldades).

4. Exposição e acionamento de mecanismos legais: respaldados pela legislação que rege a educação pública brasileira, gestores escolares usam frequentemente argumentos legais com os familiares que negligenciam seu papel no aprendizado dos alunos. Sete dos dez gestores entrevistados apontaram a utilização da estratégia. Os familiares são colocados numa situação que Alford (2009) traz como "obligatees" ou obrigados a coproduzir, na qual eles ficam susceptíveis a algum ônus caso não coproduzam, no caso da educação, risco de perder a tutela do aluno, como apresentado no Estatuto da Criança e do Adolescente. Foram citadas como estratégias tanto a um aviso de que mecanismos legais seriam acionados - o que, segundo a opinião dos gestores, tende a funcionar -, assim como o acionamento propriamente dito. Os mecanismos citados foram o Conselho Tutelar, o Ministério Público e a Vara da Infância.

5. Reconhecimento dos êxitos do estudante: a quinta estratégia identificada tem como objetivo aumentar a motivação dos familiares com a educação pública, representada pela escola, a partir do reconhecimento dos êxitos dos alunos. Segundo os gestores, os familiares tendem a ter uma ideia de que a escola só contata a família para reclamar das atitudes da criança ou pedir alguma colaboração, contexto em que o contato feito pela escola é percebido com maus olhos por quaisquer familiares. Fazendo contatos com um teor positivo, a escola geraria maior motivação à coprodução. Exemplos das estratégias que foram enquadradas nessa categoria são o certificado de aluno destaque, recompensa por participação com "escambo" (moeda da escola que pode ser trocada por lanches nas festas e objetos nos bazares), bem como a promoção de contatos dos professores para dar retornos positivos quanto ao desenvolvimento dos alunos aos familiares.

\subsection{Influência do perfil do usuário nas formas de coprodução}

Para entender a influência do perfil sociodemográfico dos familiares de alunos nas formas de produção foi considerada uma amostra que incluiu 270 familiares de estudantes de 10 escolas da região do Distrito Federal, um dos sujeitos respondeu apenas questões 
referentes ao perfil sóciodemográfico, sendo retirado da pesquisa, retando 269 casos para análise.

\subsubsection{Perfil sociodemográfico da amostra}

A amostra é formada por uma maioria do sexo feminino (82.4\%) e tem idade entre 25 e 44 anos (82.8\%), sendo a média de idade de 36.9 anos. Predominam os familiares com o Ensino Médio (52.9\%), seguindo-se os que têm Graduação (20.7\%), o Ensino Fundamental (19.2\%) e uma Pós-graduação (7.3\%). Quanto à ocupação, 64.9\% são trabalhadores ativos: $33.6 \%$ são empregados do setor privado, $21.0 \%$ são autônomos e $10.3 \%$ são servidores públicos. Existem ainda $17.2 \%$ dono(a)s de casa, $10.3 \%$ desempregados e $7.6 \%$ estudantes. A grande maioria das famílias reside no mesmo bairro da escola que os estudantes frequentam $(78.4 \%)$.

Tabela 4 - Perfil sociodemográfico da amostra.

\begin{tabular}{|c|c|c|c|}
\hline VARIÁVEIS & Categorias & $\mathbf{n}$ & $\%$ \\
\hline \multirow[t]{2}{*}{ Gênero $(\mathrm{N}=261)$} & Masculino & 46 & $17.6 \%$ \\
\hline & Feminino & 215 & $82.4 \%$ \\
\hline Idade $(\mathrm{N}=257)$ & De 19 a 24 anos & 10 & $3.9 \%$ \\
\hline Mínimo - máximo: 19 - 73 & De 25 a 34 anos & 97 & $37.7 \%$ \\
\hline \multirow[t]{4}{*}{ Média (desvio-padrão): 36.9 (8.5) } & De 35 a 44 anos & 116 & $45.1 \%$ \\
\hline & De 45 a 54 anos & 25 & $9.7 \%$ \\
\hline & De 55 a 64 anos & 5 & $1.9 \%$ \\
\hline & De 65 a 73 anos & 4 & $1.6 \%$ \\
\hline \multirow[t]{4}{*}{ Nível de escolaridade $(\mathrm{N}=261)$} & Ensino Fundamental & 50 & $19.2 \%$ \\
\hline & Ensino Médio & 138 & $52.9 \%$ \\
\hline & Graduação & 54 & $20.7 \%$ \\
\hline & Pós-graduação & 19 & $7.3 \%$ \\
\hline \multirow[t]{6}{*}{ Ocupação $(\mathrm{N}=262)$} & Autônomo & 55 & $21.0 \%$ \\
\hline & Servidor Público & 27 & $10.3 \%$ \\
\hline & Empregado do Setor Privado & 88 & $33.6 \%$ \\
\hline & Dono(a) de casa (familiar que é 'do lar') & 45 & $17.2 \%$ \\
\hline & Estudante & 20 & $7.6 \%$ \\
\hline & Desempregado & 27 & $10.3 \%$ \\
\hline \multirow{2}{*}{$\begin{array}{l}\text { Reside no mesmo bairro da escola } \\
(\mathrm{N}=269)\end{array}$} & Não & 58 & $21.6 \%$ \\
\hline & Sim & 211 & $78.4 \%$ \\
\hline \multirow[t]{5}{*}{ Escola $(\mathrm{N}=269)$} & Escola 1 & 8 & $3.0 \%$ \\
\hline & Escola 2 & 15 & $5.6 \%$ \\
\hline & Escola 3 & 22 & $8.2 \%$ \\
\hline & Escola 4 & 32 & $11.9 \%$ \\
\hline & Escola 5 & 34 & $12.6 \%$ \\
\hline
\end{tabular}


A caracterização das famílias quanto a hábitos familiares é apresentada na Tabela 5 Caraterização da amostra quanto aos hábitos familiares.. Ver televisão destaca-se como a forma de lazer mais frequente da família, referida por mais de 3 em cada 4 participantes (77.7\%). Com percentagens muito inferiores (menos de metade) seguem-se o cinema $(36.1 \%)$, a leitura $(34.9 \%)$, o esporte $(28.3 \%)$ e o teatro $(5.6 \%)$.

Quanto a práticas familiares, mais de metade das famílias realiza controle e planejamento financeiro, contendo a renda familiar e as diversas despesas (75.8\%), faz lista de compras para ir ao supermercado $(71.8 \%)$ e possui o hábito de se comunicar pela escrita, com bilhetes, mensagens etc. (62.0\%). Uma percentagem inferior escreve lista de tarefas a fazer para organizar e controlar as atividades domésticas (38.7\%) e faz um planejamento das refeições listando o que será servido (26.2\%).

Em média, cada família gasta 3.9 horas semanais lendo, com cerca de metade a referir que gasta mais do que zero até 2 horas $(51.1 \%)$. Apenas $6.8 \%$ referiram que não gastam nenhuma com leitura. Quanto às horas de interação com o estudante, mais de metade referiu mais do que zero até 10 horas, sendo o tempo médio de interação semanal de 15.9 horas. Apenas $2.1 \%$ referiram não ter qualquer tempo de interação com o estudante. A grande maioria (84.9\%) referiu que conhece alguma forma de apoiar o aluno.

Tabela 5 - Caraterização da amostra quanto aos hábitos familiares.

\begin{tabular}{|c|c|c|}
\hline VARIÁVEIS & $\mathbf{n}$ & $\%$ \\
\hline \multicolumn{3}{|l|}{ Formas de lazer da família ${ }^{(1)}(\mathrm{N}=269)$} \\
\hline Televisão & 209 & $77.7 \%$ \\
\hline Cinema & 97 & $36.1 \%$ \\
\hline Leitura & 94 & $34.9 \%$ \\
\hline Esporte & 76 & $28.3 \%$ \\
\hline Teatro & 15 & $5.6 \%$ \\
\hline Outro & 49 & $18.2 \%$ \\
\hline \multicolumn{3}{|l|}{ Práticas familiares $^{(1)}$} \\
\hline Possui o hábito de se comunicar pela escrita, com bilhetes, mensagens etc. $(\mathrm{N}=255)$ & 158 & $62.0 \%$ \\
\hline Fazer lista de compras para ir ao supermercado $(\mathrm{N}=252)$ & 181 & $71.8 \%$ \\
\hline Fazer um planejamento das refeições listando o que será servido ( $\mathrm{N}=248)$ & 65 & $26.2 \%$ \\
\hline Escrever lista de tarefas a fazer para organizar e controlar as atividades domésticas $(\mathrm{N}=248)$ & 96 & $38.7 \%$ \\
\hline $\begin{array}{l}\text { Realizar controle e planejamento financeiro, contendo a renda familiar e as diversas despesas ( } \mathrm{N} \\
=248)\end{array}$ & 188 & $75.8 \%$ \\
\hline
\end{tabular}




\begin{tabular}{|c|c|c|}
\hline \multicolumn{3}{|c|}{ Horas semanais que os membros da família gastam lendo $(\mathrm{N}=221)$} \\
\hline \multicolumn{3}{|c|}{ Mínimo - máximo: $0-24 ;$ Mediana = 2; Média (desvio-padrão) = 3.9 (4.5) } \\
\hline 0 horas & 15 & $6.8 \%$ \\
\hline ]0-2] horas & 113 & $51.1 \%$ \\
\hline ]2-4] horas & 27 & $12.2 \%$ \\
\hline ]4-6] horas & 23 & $10.4 \%$ \\
\hline ]6-8] horas & 16 & $7.2 \%$ \\
\hline ]8-10] horas & 11 & $5.0 \%$ \\
\hline ]10-12] horas & 4 & $1.8 \%$ \\
\hline$>12$ horas & 12 & $5.4 \%$ \\
\hline
\end{tabular}

\begin{tabular}{|c|c|c|}
\hline \multicolumn{3}{|c|}{ Horas semanais de interação do estudante com a família $(\mathrm{N}=237)$} \\
\hline \multicolumn{3}{|c|}{ Mínimo - máximo: 0 - 90; Mediana: 8; Média (desvio-padrão) = 15.9 (17.8) } \\
\hline 0 horas & 5 & $2.1 \%$ \\
\hline ]0-10] horas & 132 & $55.7 \%$ \\
\hline ]10-20] horas & 27 & $11.4 \%$ \\
\hline ]20-30] horas & 45 & $19.0 \%$ \\
\hline ]30-40] horas & 6 & $2.5 \%$ \\
\hline ]40-50] horas & 9 & $3.8 \%$ \\
\hline ]50-60] horas & 5 & $2.1 \%$ \\
\hline$>60$ horas & 8 & $3.4 \%$ \\
\hline \multicolumn{3}{|c|}{ Conhece alguma forma de apoiar $\mathrm{o}$ aluno? $(\mathrm{N}=258)$} \\
\hline Não & 39 & $15.1 \%$ \\
\hline Sim & 219 & $84.9 \%$ \\
\hline \multicolumn{3}{|c|}{ Expectativa de escolaridade do estudante $(\mathrm{N}=263)$} \\
\hline Ensino Fundamental & 24 & $9.1 \%$ \\
\hline Ensino Médio & 26 & $9.9 \%$ \\
\hline Graduação & 71 & $27.0 \%$ \\
\hline Pós-graduação & 142 & $54.0 \%$ \\
\hline
\end{tabular}

Os participantes revelaram ter expectativas elevadas relativamente à escolaridade dos estudantes, com mais de metade a referir pós-graduação (54.0\%). Cerca de um em cada quatro (27.0\%) graduação e menos de 10\% referiram Ensino Médio (9.9\%) ou Ensino Fundamental $(9.1 \%)$.

O cruzamento da escolaridade dos familiares com a expectativa de escolaridade (Tabela 6 - Escolaridade dos familiares vs. expectativa quanto à escolaridade dos alunos. mostra que familiares com maior nível de escolaridade têm expectativas mais elevadas em relação à escolaridade dos estudantes sob sua responsabilidade. De fato, a expectativa depende significativamente da escolaridade dos familaires (Teste Qui-quadrado: $p<0.001$ ) e observa-se uma correlação positiva entre ambas as variáveis $(\mathrm{R}=0.332 ; p<0.001)$. É notável também que a maioria dos familiares $(71,38 \%)$ tem a expectativa de que seus tutelados tenham um nível de escolaridade superior ao próprio nível, representado pelas ocorrências ressaltadas em cinza na Tabela 6 - Escolaridade dos familiares vs. expectativa quanto à escolaridade dos alunos. 
Tabela 6 - Escolaridade dos familiares vs. expectativa quanto à escolaridade dos alunos.

\begin{tabular}{|c|c|c|c|c|c|}
\hline \multirow[b]{2}{*}{$\begin{array}{l}\text { ESCOLARIDADE } \\
\text { FAMILIARES }\end{array}$} & \multirow[b]{2}{*}{ DOS } & \multicolumn{4}{|c|}{ EXPECTATIVA DE ESCOLARIDADE } \\
\hline & & Ens. Fundamental & Ensino Médio & Graduação & Pós-graduação \\
\hline Ensino Fundamental $(\mathrm{n}=48)$ & & $8(16.7 \%)$ & $5(10.4 \%)$ & $20(41.7 \%)$ & $15(31.3 \%)$ \\
\hline Ensino Médio $(\mathrm{n}=137)$ & & $10(7.3 \%)$ & $18(13.1 \%)$ & $43(31.4 \%)$ & $66(48.2 \%)$ \\
\hline Graduação $(\mathrm{n}=54)$ & & $4(7.4 \%)$ & $0(0.0 \%)$ & $8(14.8 \%)$ & $42(77.8 \%)$ \\
\hline Pós-graduação (n = 19) & & $2(10.5 \%)$ & $0(0.0 \%)$ & $0(0.0 \%)$ & $17(89.5 \%)$ \\
\hline
\end{tabular}

Segundo Alves et al. (2013, p. 586), “os grupos sociais que mais dependem do sucesso escolar para ascender socialmente tenderiam a apresentar níveis de aspiração e graus de investimento mais elevados na escolarização dos seus filhos." Os autores apresentam que a classe média tenderia a explicitar maiores expectativas, ao passo que as elites econômicas teriam menores, uma vez que possuiriam outros recursos e assim depederiam menos da educação, e as classes mais populares não criariam tal expectativa por possuir menor capital cultural. Dessa forma, os resultados apresentados na Tabela 6 - Escolaridade dos familiares vs. expectativa quanto à escolaridade dos alunos.indicam um perfil de expectativa familiar quanto a educação positiva à coprodução, apesar de o nível de escolaridade não se mostrar elevado.

\subsubsection{Relação entre Perfil e as formas de coprodução Educação}

Para uma análise mais detalhada dos fatores que influenciam a coprodução foram conduzidos modelos de regressão logística para estudar os fatores que influenciam cada uma das formas de coprodução da educação pública tratadas na pesquisa: Participar de festas e eventos da escola - coprodução social; Participar do Conselho Escolar ou Associação de Pais e Professores - coprodução política; Apoiar na elaboração das tarefas de casa e Pedir conselhos da escola sobre como auxiliar o filho - coprodução pedagógica; Executar atividades de desenvolvimento da escola e Doar recursos financeiros ou de outros tipos coprodução econômica. Os resultados são apresentados nas Tabela 7 - Modelos de regressão logística com a coprodução social e a coprodução política como variáveis dependentes., Tabela 8 - Modelos de regressão logística com cada um dos 2 itens da coprodução pedagógica como variáveis dependentes. e Tabela 9 - Modelos de regressão logística com cada um dos 2 itens da coprodução econômica como variáveis dependentes. 
Tabela 7 - Modelos de regressão logística com a coprodução social e a coprodução política como variáveis dependentes.

\begin{tabular}{|c|c|c|c|c|}
\hline \multirow{3}{*}{ VARIÁVEIS INDEPENDENTES } & \multicolumn{4}{|c|}{ VARIÁVEL DEPENDENTE } \\
\hline & \multicolumn{2}{|c|}{$\begin{array}{c}\text { COPRODUÇÃO } \\
\text { SOCIAL } \\
\text { Participar de festas e } \\
\text { eventos da escola } \\
\end{array}$} & \multicolumn{2}{|c|}{$\begin{array}{l}\text { COPRODUÇÃO POLÍTICA } \\
\text { Participar do Conselho Escolar } \\
\text { ou Ass. de Pais e Professores }\end{array}$} \\
\hline & OR & $p$ & OR & $p$ \\
\hline \multicolumn{5}{|l|}{ VARIÁVEIS SOCIODEMOGRÁFICAS } \\
\hline \multicolumn{5}{|l|}{ Gênero (Ref: masculino) } \\
\hline Feminino & 0.83 & 0.629 & 1.69 & 0.139 \\
\hline Idade & 1.01 & 0.439 & 1.00 & 0.870 \\
\hline \multicolumn{5}{|l|}{ Escolaridade (Ref: Ens. Fundamental) } \\
\hline Ensino Médio & 1.10 & 0.793 & 0.70 & 0.277 \\
\hline Graduação/Pós-graduação & 1.50 & 0.340 & 0.41 & $\mathbf{0 . 0 2 0}$ \\
\hline \multicolumn{5}{|l|}{ Ocupação (Ref: Trabalhador ativos) } \\
\hline Dono(a) de casa & 2.30 & 0.101 & 1.75 & 0.097 \\
\hline Desempregado & 0.49 & 0.104 & 1.47 & 0.361 \\
\hline Estudante & 0.29 & $\mathbf{0 . 0 1 0}$ & 0.61 & 0.362 \\
\hline \multicolumn{5}{|l|}{ Reside no mesmo bairro da escola (Ref: não) } \\
\hline $\operatorname{Sim}$ & 1.16 & 0.648 & 1.36 & 0.329 \\
\hline \multicolumn{5}{|l|}{ HÁBITOS FAMILIARES } \\
\hline \multicolumn{5}{|l|}{ Formas de lazer (Ref: Não) } \\
\hline Televisão (Sim) & 1.10 & 0.779 & 0.91 & 0.757 \\
\hline Cinema (Sim) & 7.07 & $<0.001$ & 0.65 & 0.110 \\
\hline Leitura (Sim) & 2.55 & 0.005 & 1.07 & 0.791 \\
\hline Esporte (Sim) & 1.93 & 0.056 & 0.67 & 0.157 \\
\hline Teatro (Sim) & 5.02 & 0.123 & 0.80 & 0.685 \\
\hline \multicolumn{5}{|l|}{ Práticas familiares (Ref: Não) } \\
\hline Hábito de se comunicar pela escrita (Sim) & 2.86 & $<0.001$ & 0.79 & 0.386 \\
\hline Faz lista de compras supermercado (Sim) & 1.22 & 0.527 & 1.13 & 0.667 \\
\hline Faz planejamento das refeições (Sim) & 1.30 & 0.454 & 3.72 & $<0.001$ \\
\hline Escreve lista de tarefas (Sim) & 1.36 & 0.327 & 2.14 & 0.005 \\
\hline Realiza controle e planejamento financeiro (Sim) & 1.26 & 0.491 & 1.62 & 0.130 \\
\hline Horas semanais de leitura & 1.02 & 0.532 & 0.98 & 0.595 \\
\hline Horas semanais de interação & 1.02 & 0.046 & 0.99 & 0.216 \\
\hline$R^{2}$ de Nagelkerke & \multicolumn{2}{|c|}{$32.0 \%$} & \multicolumn{2}{|c|}{$20.6 \%$} \\
\hline
\end{tabular}

Quanto à participação em festas e eventos da escola, que representa a coprodução social, observou-se que a ocupação, as formas de lazer e as horas de interação com o estudante têm influência significativa. Comparativamente com os trabalhadores ativos servidores públicos, autônomos e no setor privado, os dono(a)s de casa têm 2.3 vezes mais chances de participar de festas e eventos da escola ( $\mathrm{OR}=2.30 ; p=0.101)$. Por outro lado, os desempregados $(\mathrm{OR}=0.49 ; p=0.104)$ e os estudantes $(\mathrm{OR}=0.29 ; p=0.010)$ têm menos chances de participar do que os trabalhadores ativos (efeito apenas significativo no caso dos 
estudantes). Essa relação condiz com o achado de Parrado et al. (2013) de que, na Dinamarca, estar ativo no mercado de trabalho tem uma relação negativa com a coprodução do cuidado com o meio ambiente. Todavia, no mesmo estudo foi identificado um efeito positivo da ocupação na coprodução da segurança pública na Alemanha e Reino Unido. Uma vez que a participação em eventos escolares envolve algum gasto financeiro, é possível que a menor participação de desempregados e estudantes se dê devido à tendência de estes terem, em geral, menor renda.

Quanto às formas de lazer, os familaires que referem o cinema $(\mathrm{OR}=7.07 ; p<$ $0.001)$, a leitura $(\mathrm{OR}=2.55 ; p=0.005)$ e o esporte $(\mathrm{OR}=1.93 ; p=0.056)$ têm mais chance de participar de festas e eventos da escola, comparativamente com os que não referiram essas atividades. O hábito de ir ao cinema se destacou fortemente, tendo uma família com este hábito sete vezes mais chances de participar de eventos sociais da escola. As variáveis independentes consideradas na Tabela 7 - Modelos de regressão logística com a coprodução social e a coprodução política como variáveis dependentes.explicam $32.0 \%$ da participação dos familiares neste tipo de coprodução.

No que se refere a participar do Conselho Escolar ou da Associação de Pais e Professores, que repesenta a coprodução política, a chance de participar diminui com o aumento da escolaridade, sendo o efeito significativo no caso dos familiares com graduação ou pós-graduação. Estes têm $59 \%$ menos chances $(\mathrm{OR}=0.41 ; p=0.020)$ de participar do que os pais que têm o Ensino Fundamental. Isso vai de encontro aos resultados de Parrado et al. (2013), que encontraram uma relação positiva entre a escolaridade e as práticas de coprodução de perfil mais consultivo, condizente com a coprodução política Os familiares que fazem planejamento das refeições ( $\mathrm{OR}=3.72 ; p<0.001)$ e que escrevem lista de tarefas $(\mathrm{OR}=2.14 ; p=0.005)$ têm mais chance de participar do Conselho Escolar ou da Associação de Pais e Professores. Nenhuma das outras variáveis apresentadas na Tabela 7 - Modelos de regressão logística com a coprodução social e a coprodução política como variáveis dependentes. influencia significativamente a participação do Conselho Escolar ou da Associação de Pais e Professores.

As variáveis independentes consideradas na Tabela 7 - Modelos de regressão logística com a coprodução social e a coprodução política como variáveis dependentes. explicam 20.6\% da participação do Conselho Escolar ou da Associação de Pais e Professores.

$\mathrm{Na}$ Tabela 8 - Modelos de regressão logística com cada um dos 2 itens da coprodução pedagógica como variáveis dependentes. são apresentados os resultados do estudo da influência dos fatores sociodemográficos e familiares na coprodução pedagógica 
(apoiar na elaboração das tarefas de casa/ pedir conselhos da escola sobre como auxiliar o filho) e em cada uma das formas de coprodução pedagógica tratadas na pesquisa. Cada uma das variáveis foi dicotomizada $(0=$ nenhuma atividade; $1=$ pelo menos uma das duas atividades) e considerada como variável dependente em modelos de regressão logística.

Tabela 8 - Modelos de regressão logística com cada um dos 2 itens da coprodução pedagógica como variáveis dependentes.

\begin{tabular}{|c|c|c|c|c|c|c|}
\hline \multirow{4}{*}{ VARIÁVEIS INDEPENDENTES } & \multicolumn{6}{|c|}{ VARIÁVEIS DEPENDENTES } \\
\hline & \multicolumn{6}{|c|}{ COPRODUÇÃO PEDAGÓGICA } \\
\hline & \multicolumn{2}{|c|}{$\begin{array}{l}\text { Coprodução } \\
\text { pedagógica }\end{array}$} & \multicolumn{2}{|c|}{$\begin{array}{l}\text { Apoiar na elaboração } \\
\text { das tarefas de casa }\end{array}$} & \multicolumn{2}{|c|}{$\begin{array}{l}\text { Pedir conselhos da } \\
\text { escola sobre como } \\
\text { auxiliar o filho }\end{array}$} \\
\hline & OR & $\mathbf{p}$ & OR & $p$ & OR & $p$ \\
\hline \multicolumn{7}{|l|}{ VARIÁVEIS SOCIODEMOGRÁFICAS } \\
\hline \multicolumn{7}{|l|}{ Gênero (Ref: masculino) } \\
\hline Feminino & 1.50 & 0.335 & 1.11 & 0.786 & 1.40 & 0.313 \\
\hline Idade & 1.00 & 0.919 & 0.98 & 0.179 & 1.02 & 0.139 \\
\hline \multicolumn{7}{|l|}{ Escolaridade (Ref: Ens. Fundamental) } \\
\hline Ensino Médio & 0.68 & 0.436 & 0.96 & 0.911 & 0.97 & 0.932 \\
\hline Graduação/Pós-graduação & 0.86 & 0.783 & 1.62 & 0.277 & 1.27 & 0.516 \\
\hline \multicolumn{7}{|l|}{ Ocupação (Ref: Trabalhador ativos) } \\
\hline Dono(a) de casa & 1.19 & 0.742 & 0.97 & 0.947 & 1.36 & 0.364 \\
\hline Desempregado & 0.52 & 0.206 & 0.56 & 0.191 & 0.55 & 0.178 \\
\hline Estudante & 0.45 & 0.153 & 0.52 & 0.190 & 1.06 & 0.900 \\
\hline \multicolumn{7}{|l|}{ Vive no mesmo bairro da escola (Ref: não) } \\
\hline Sim & 0.62 & 0.314 & 0.80 & 0.532 & 1.02 & 0.946 \\
\hline \multicolumn{7}{|l|}{ HÁBITOS FAMILIARES } \\
\hline \multicolumn{7}{|l|}{ Formas de lazer (Ref: Não) } \\
\hline Televisão (Sim) & 1.24 & 0.589 & 0.97 & 0.925 & 0.85 & 0.574 \\
\hline Cinema (Sim) & 1.15 & 0.702 & 1.10 & 0.748 & 0.76 & 0.284 \\
\hline Leitura (Sim) & 1.25 & 0.555 & 0.86 & 0.623 & 1.96 & 0.009 \\
\hline Esporte (Sim) & 0.58 & 0.129 & 0.83 & 0.542 & 0.92 & 0.773 \\
\hline Teatro (Sim) & (1) & (1) & (1) & (1) & 1.15 & 0.799 \\
\hline \multicolumn{7}{|l|}{ Práticas familiares (Ref: Não) } \\
\hline Hábito de se comunicar pela escrita (Sim) & 1.16 & 0.677 & 1.14 & 0.670 & 1.39 & 0.208 \\
\hline Faz lista de compras supermercado (Sim) & 2.04 & 0.055 & 1.42 & 0.279 & 1.89 & 0.031 \\
\hline Faz planejamento das refeições (Sim) & 4.21 & 0.021 & 2.53 & 0.024 & 1.91 & 0.026 \\
\hline Escreve lista de tarefas (Sim) & 1.18 & 0.660 & 1.15 & 0.655 & 1.64 & 0.059 \\
\hline $\begin{array}{l}\text { Realiza controle e planejamento financeiro } \\
\text { (Sim) }\end{array}$ & 1.99 & 0.084 & 1.69 & 0.117 & 1.98 & 0.029 \\
\hline Horas semanais de leitura & 0.98 & 0.699 & 0.99 & 0.788 & 1.03 & 0.260 \\
\hline Horas semanais de interação & 0.99 & 0.486 & 1.00 & 0.963 & 0.99 & 0.160 \\
\hline $\mathbf{R}^{2}$ de Nagelkerke & \multicolumn{2}{|c|}{$R^{2}=14.4 \%$} & \multicolumn{2}{|c|}{$16.6 \%$} & \multicolumn{2}{|c|}{$20.3 \%$} \\
\hline
\end{tabular}

OR - Odds Ratio; $p$ - valor de significância. (1) não é possível estimar os OR devido a frequência zero: 100\% dos familiares que referem teatro apoiam nas tarefas e $75 \%$ dos familiares que não referem teatro apoiam nas tarefas (Teste Exato de Fisher: $\mathrm{p}=0.026)$

Os resultados mostram que os familiares que fazem lista de compras para o supermercado $(\mathrm{OR}=2.04 ; p=0.055)$ e que fazem planejamento das refeições $(\mathrm{OR}=4.21 ; p$ 
$=0.021)$ aumentam as chances de coprodução pedagógica. Nenhuma das outras variáveis influencia significativamente a coprodução pedagógica.

O apoio na elaboração das tarefas de casa apenas é influenciado significativamente pela variável "faz planejamento das refeições" ( $\mathrm{OR}=2.83 ; \mathrm{p}=0.052)$. Neste caso, os familiares que fazem planejamento das refeições têm 2.83 vezes mais chances de apoiar na elaboração das tarefas de casa. No caso do teatro, observa-se que $100 \%$ dos familiares que citam teatro apoiam na elaboração das tarefas de casa e $75 \%$ dos familiares que não citam teatro apoiam nas tarefas. Por não ser possível estimar os OR devido à frequência zero em uma das células, foi realizado o Teste Exato de Fisher que foi significativo $(p=0.026)$, ou seja, os familiares de alunos que citam teatro como forma de lazer têm mais chance de apoiar na elaboração das tarefas de casa.

Os familiares que fazem lista de compras para o supermercado $(\mathrm{OR}=1.89 ; \mathrm{p}=$ 0.031), os que fazem planejamento das refeições $(\mathrm{OR}=1.91 ; \mathrm{p}=0.026)$, os que escrevem lista de tarefas $(\mathrm{OR}=1.64 ; \mathrm{p}=0.059)$ e os que realizam controle e planejamento financeiro $(\mathrm{OR}=1.98 ; \mathrm{p}=0.029)$ têm mais chances de pedir conselhos da escola sobre como auxiliar o filho do que os que não o fazem. Nenhuma das outras variáveis influencia significativamente o pedido de conselhos da escola sobre como auxiliar o filho. Esses achados são condizentes com os resultados auferidos por Alves et al. (2013) de que a ordem racional doméstica (representada pelos hábitos citados) influencia positivamente o aprendizado. É importante ressaltar que Alves et al. (2013) estudaram o impacto da ordem racional doméstica diretamente no aprendizado, e não na coprodução, todavia os próprios autores explicam que a a ordem racional doméstica afeta o aprendizado por meio da influência da família no aluno.

As variáveis independentes consideradas na Tabela 8 - Modelos de regressão logística com cada um dos 2 itens da coprodução pedagógica como variáveis dependentes. explicam $16.5 \%$ do apoio na elaboração das tarefas de casa e $20.3 \%$ do pedido de conselhos da escola sobre como auxiliar o filho.

Na Tabela 9 - Modelos de regressão logística com cada um dos 2 itens da coprodução econômica como variáveis dependentes.são apresentados os resultados do estudo da influência dos fatores sociodemográficos e familiares na coprodução econômica (executar atividades de desenvolvimento da escola/ doar recursos financeiros ou de outros tipos). Cada uma das variáveis foi dicotomizada ( $0=$ nenhuma atividade; $1=$ pelo menos uma das duas atividades) e considerada como variável dependente em modelos de regressão logística. 
Tabela 9 - Modelos de regressão logística com cada um dos 2 itens da coprodução econômica como variáveis dependentes.

\begin{tabular}{|c|c|c|c|c|c|c|}
\hline \multirow{4}{*}{ VARIÁVEIS INDEPENDENTES } & \multicolumn{6}{|c|}{ VARIÁVEIS DEPENDENTES } \\
\hline & \multicolumn{6}{|c|}{ COPRODUÇÃO ECONÔMICA } \\
\hline & \multicolumn{2}{|c|}{$\begin{array}{l}\text { Coprodução } \\
\text { econômica }\end{array}$} & \multicolumn{2}{|c|}{$\begin{array}{c}\text { Executar atividades } \\
\text { de desenvolvimento } \\
\text { da escola }\end{array}$} & \multicolumn{2}{|c|}{$\begin{array}{c}\text { Doar recursos } \\
\text { financeiros ou de } \\
\text { outros tipos }\end{array}$} \\
\hline & OR & $p$ & OR & $p$ & OR & $p$ \\
\hline \multicolumn{7}{|l|}{ VARIÁVEIS SOCIODEMOGRÁFICAS } \\
\hline \multicolumn{7}{|l|}{ Gênero (Ref: masculino) } \\
\hline Feminino & 0.59 & 0.103 & 0.81 & 0.562 & 0.69 & 0.278 \\
\hline Idade & 1.02 & 0.316 & 1.02 & 0.177 & 1.03 & 0.050 \\
\hline \multicolumn{7}{|l|}{ Escolaridade (Ref: Ens. Fundamental) } \\
\hline Ensino Médio & 1.95 & 0.055 & 1.30 & 0.505 & 2.30 & 0.052 \\
\hline Graduação/Pós-graduação & 2.58 & 0.014 & 1.25 & 0.610 & 3.87 & 0.003 \\
\hline \multicolumn{7}{|l|}{ Ocupação (Ref: Trabalhador ativos) } \\
\hline Dono(a) de casa & 1.08 & 0.814 & 1.14 & 0.724 & 1.17 & 0.667 \\
\hline Desempregado & 1.55 & 0.296 & 1.57 & 0.310 & 1.17 & 0.727 \\
\hline Estudante & 0.67 & 0.410 & 0.56 & 0.366 & 0.58 & 0.356 \\
\hline \multicolumn{7}{|l|}{ Reside no mesmo bairro da escola (Ref: não) } \\
\hline Sim & 1.05 & 0.877 & 2.11 & 0.057 & 0.70 & 0.255 \\
\hline \multicolumn{7}{|l|}{ HÁBITOS FAMILIARES } \\
\hline \multicolumn{7}{|l|}{ Formas de lazer (Ref: Não) } \\
\hline Televisão (Sim) & 0.95 & 0.868 & 1.14 & 0.694 & 0.75 & 0.350 \\
\hline Cinema (Sim) & 1.19 & 0.500 & 0.88 & 0.657 & 1.67 & 0.061 \\
\hline Leitura (Sim) & 1.94 & 0.011 & 1.56 & 0.125 & 2.42 & 0.001 \\
\hline Esporte (Sim) & 1.10 & 0.734 & 0.98 & 0.947 & 1.30 & 0.358 \\
\hline Teatro (Sim) & 4.68 & 0.020 & 3.70 & 0.015 & 2.83 & 0.052 \\
\hline \multicolumn{7}{|l|}{ Práticas familiares (Ref: Não) } \\
\hline Hábito de se comunicar pela escrita (Sim) & 1.21 & 0.455 & 1.44 & 0.228 & 1.30 & 0.356 \\
\hline Faz lista de compras supermercado (Sim) & 2.07 & 0.013 & 1.80 & 0.092 & 2.76 & 0.004 \\
\hline Faz planejamento das refeições (Sim) & 1.82 & 0.040 & 1.84 & 0.052 & 2.97 & $<0.001$ \\
\hline Escreve lista de tarefas (Sim) & 1.14 & 0.625 & 1.09 & 0.763 & 1.74 & 0.049 \\
\hline Realiza controle e planejamento financeiro (Sim) & 2.33 & 0.008 & 1.41 & 0.344 & 2.99 & 0.005 \\
\hline Horas semanais de leitura & 1.03 & 0.334 & 1.01 & 0.824 & 1.05 & 0.134 \\
\hline Horas semanais de interação & 0.99 & 0.380 & 0.99 & 0.331 & 1.00 & 0.960 \\
\hline $\mathbf{R}^{2}$ de Nagelkerke & \multicolumn{2}{|c|}{$R^{2}=18.3 \%$} & \multicolumn{2}{|c|}{$29.5 \%$} & \multicolumn{2}{|c|}{$31.1 \%$} \\
\hline
\end{tabular}

OR - Odds Ratio; $p$ - valor de significância. (1) não é possível estimar os OR devido a frequência zero: 100\% dos familiares que referem teatro apoiam nas tarefas e $75 \%$ dos familiares que não referem teatro apoiam nas tarefas (Teste Exato de Fisher: $\mathrm{p}=0.026)$

As chances de coprodução econômica aumentam com o aumento da graduação (significativo no caso dos familiares com graduação/pós-graduação: OR $=2.58 ; p=0.014$ ). Também neste caso, os familiares que fazem lista de compras do supermercado $(\mathrm{OR}=2.07 ; p$ $=0.013)$ e que fazem planejamento das refeições $(\mathrm{OR}=1.82 ; p=0.040)$ têm mais chances de coprodução econômica. As chances de coprodução econômica são também mais elevadas entre familiares de citam o teatro com forma de lazer ( $\mathrm{OR}=4.68 ; p=0.020)$ e aqueles que realizam controle e planejamento financeiro $(\mathrm{OR}=2.33 ; p=0.008)$. 
Os familiares que residem no mesmo bairro da escola ( $\mathrm{OR}=2.11 ; p=0.057)$, os que referem a ida ao teatro como forma de lazer ( $\mathrm{OR}=3.70 ; p=0.015)$ e os que fazem planejamento das refeições $(\mathrm{OR}=1.84 ; p=0.052)$ têm maiores chances de executar atividades de desenvolvimento da escola. Nenhuma das outras variáveis influencia significativamente a execução de atividades de desenvolvimento da escola.

A chance de doar recursos financeiros ou de outros tipos aumenta com o aumento da idade $(\mathrm{OR}=1.03 ; p=0.050)$ e com o aumento do nível de escolaridade: os familiares com Ensino Médio têm 2.3 vezes mais chances $(\mathrm{OR}=2.30 ; p=0.052)$ e os familiares com graduação ou pós-graduação têm 3.87 vezes mais chances $(\mathrm{OR}=3.87 ; p=0.003)$ de doar recursos financeiros ou de outros tipos, comparativamente com os familiares com o Ensino Fundamental. É possível inferir que essa relação entre nível de escolaridade, idade e doação de recursos financeiros seja mediada pela tendência de aumento da renda famíliar à medida que os familiares ficam mais velhos e têm maior escolaridade. Nas pesquisas sobre a influência do perfil dos usuários nas formas de coprodução, como em Parrado et al. (2013) e Bovaird et al. (2014), as explicações referentes à variável idade, sempre se relacionaram ao fato de determinadas idades serem mais propensas a utilizar mais intensamente determinados serviços, como idosos e serviços de saúde. No caso da educação pública, todos os usuários utilizam o serviço com a mesma intensidade, de forma que tal interpretação não pode ser feita.

Quanto aos hábitos familiares, os que referem o cinema ( $\mathrm{OR}=1.67 ; p=0.061$ ), a leitura $(\mathrm{OR}=2.42 ; p=0.001)$ e o teatro $(\mathrm{OR}=2.83 ; p=0.052)$ têm mais chances de doação de recursos financeiros ou de outros tipos. Observa-se ainda que os familiares que fazem lista de compras supermercado $(\mathrm{OR}=2.76 ; p=0.004)$, fazem planejamento das refeições $(\mathrm{OR}=$ 2.97; $p<0.001)$, escrevem lista de tarefas $(\mathrm{OR}=1.74 ; p=0.049)$ e realizam controle e planejamento financeiro $(\mathrm{OR}=2.99 ; p=0.005)$ têm mais chances de doar recursos financeiros ou de outros tipos.

As variáveis independentes consideradas na Tabela 9 - Modelos de regressão logística com cada um dos 2 itens da coprodução econômica como variáveis dependentes.explicam $31.1 \%$ de doação de recursos financeiros ou de outros tipos e $29.5 \%$ da execução de atividades de desenvolvimento da escola, mas ao considerarmos a coprodução econômica como o todo. 


\subsubsection{Relação entre perfil e a coprodução individual e coletiva da Educação}

A literatura de coprodução de serviços públicos, em estudos realizados em países desenvolvidos, identificou que "a coprodução individual é muito mais comum que a coletiva" Alford e Yates (2015, p.6). Estes autores sugerem que a maioria das atividades nas quais a coprodução se mostrou mais frequente foi do tipo individual devido ao fato de não requererem interação com outras pessoas. Já a coprodução coletiva, que demanda interação com autoridades ou pares, teria se mostrado com menor frequência. Os autores ainda identificaram que as atividades que produzem majoritariamente valor individual Coprodução Individual - são mais frenquentes, ao passo que as menos observadas são aquelas que geram um valor coletivo, com um menor componente de valor privado.

Dessa forma, para estudar os fatores que influenciam a coprodução, foram conduzidos modelos de regressão linear considerando-se as variáveis coprodução coletiva e individual como variáveis dependentes e os hábitos familiares e as variáveis sociodemográficas como independentes. A análise dos coeficientes de assimetria e curtose próximos de zero mostram que não existem desvios significativos à normalidade dos dados que coloquem em causa a utilização desta técnica estatística - coprodução coletiva: coeficiente de assimetria $=0.320$ e coeficiente de curtose $=-0.351$; coprodução individual: coeficiente de assimetria $=0.111$ e coeficiente de curtose $=-0.639$.

Os resultados apresentados na Tabela 10 - Modelos de regressão linear com a coprodução coletiva e a coprodução individual como variáveis dependentes.levam a constatar que o gênero e a idade não exercem influência significativa na coprodução coletiva, tampouco na individual. O estudo de Alford e Yates (2015) identificou, conforme os resultados desta análise, que para os serviços de segurança pública e cuidado com o meio ambiente, não há relação significativa entre a coprodução e o gênero do usuário do serviço. Esse achado se diferencia do estudo conduzido por Bovaird et al. (2015), que avaliaram a coprodução individual em cinco cidades inglesas - Barnet, Bristol, Derbyshire Dales, Swansea e Wolverhampton, e identificaram apenas 20\% de associação com o gênero, sendo esta associação positiva para o gênero masculino em um caso e negativa em outro), porém verificou-se uma forte associação negativa entre a coprodução individual e a idade em $40 \%$ casos analisados. 
Tabela 10 - Modelos de regressão linear com a coprodução coletiva e a coprodução individual como variáveis dependentes.

\begin{tabular}{|c|c|c|c|c|c|c|}
\hline \multirow[b]{3}{*}{ VARIÁVEIS INDEPENDENTES } & \multicolumn{6}{|c|}{ VARIÁVEL DEPENDENTE } \\
\hline & \multicolumn{3}{|c|}{ Coprodução coletiva } & \multicolumn{3}{|c|}{ Coprodução individual } \\
\hline & $\mathbf{B}$ & $\boldsymbol{\beta}$ & $p$ & B & $\boldsymbol{\beta}$ & $p$ \\
\hline \multicolumn{7}{|l|}{ VARIÁVEIS SOCIODEMOGRÁFICAS } \\
\hline Gênero (Ref: masculino) & 0.043 & 0.020 & 0.746 & 0.019 & 0.009 & 0.891 \\
\hline \multicolumn{7}{|l|}{ Feminino } \\
\hline Idade & 0.006 & 0.064 & 0.305 & 0.008 & 0.078 & 0.211 \\
\hline \multicolumn{7}{|l|}{ Escolaridade (Ref: Ens. Fundamental) } \\
\hline Ensino Médio & -0.021 & -0.013 & 0.874 & 0.129 & 0.074 & 0.364 \\
\hline Graduação/Pós-graduação & -0.091 & -0.050 & 0.545 & 0.406 & 0.210 & 0.011 \\
\hline \multicolumn{7}{|l|}{ Ocupação (Ref: Trabalhadores ativos) } \\
\hline Dono(a) de casa & 0.274 & 0.128 & 0.040 & 0.105 & 0.046 & 0.471 \\
\hline Desempregado & 0.037 & 0.014 & 0.823 & -0.221 & -0.078 & 0.218 \\
\hline Estudante & -0.471 & -0.155 & 0.013 & -0.218 & -0.067 & 0.288 \\
\hline \multicolumn{7}{|l|}{ Reside no mesmo bairro da escola (Ref: não) } \\
\hline Sim & 0.224 & 0.114 & 0.063 & -0.112 & -0.054 & 0.381 \\
\hline \multicolumn{7}{|l|}{ HÁBITOS FAMILIARES } \\
\hline \multicolumn{7}{|l|}{ Formas de lazer (Ref: Não) } \\
\hline Televisão (Sim) & 0.021 & 0.011 & 0.861 & -0.110 & -0.053 & 0.386 \\
\hline Cinema (Sim) & 0.159 & 0.094 & 0.124 & 0.059 & 0.033 & 0.589 \\
\hline Leitura (Sim) & 0.262 & 0.154 & 0.012 & 0.330 & 0.183 & 0.003 \\
\hline Esporte (Sim) & 0.016 & 0.009 & 0.881 & 0.003 & 0.001 & 0.982 \\
\hline Teatro (Sim) & 0.442 & 0.125 & 0.041 & 0.531 & 0.142 & 0.020 \\
\hline \multicolumn{7}{|l|}{ Práticas familiares (Ref: Não) } \\
\hline Hábito de se comunicar pela escrita (Sim) & 0.215 & 0.130 & 0.038 & 0.159 & 0.089 & 0.157 \\
\hline Faz lista de compras supermercado (Sim) & 0.172 & 0.094 & 0.135 & 0.404 & 0.211 & 0.001 \\
\hline Faz planejamento das refeições (Sim) & 0.486 & 0.262 & $<0.001$ & 0.542 & 0.281 & $<0.001$ \\
\hline Escreve lista de tarefas (Sim) & 0.252 & 0.153 & 0.016 & 0.265 & 0.153 & 0.016 \\
\hline Realiza controle e planejamento financeiro (Sim) & 0.213 & 0.114 & 0.073 & 0.456 & 0.232 & $<0.001$ \\
\hline Horas semanais de leitura & 0.002 & 0.009 & 0.899 & 0.017 & 0.090 & 0.184 \\
\hline \multirow[t]{2}{*}{ Horas semanais de interação } & -0.001 & -0.012 & 0.860 & -0.002 & -0.049 & 0.449 \\
\hline & \multicolumn{3}{|c|}{$R^{2}=19.7 \%$} & \multicolumn{3}{|c|}{$\mathbf{R}^{2}=24.4 \%$} \\
\hline
\end{tabular}

B - Coeficiente de Regressão não estandardizado; $\beta$ - Coeficiente de Regressão estandardizado; $p$ - valor de significância.

Relações entre a coprodução e o gênero foram identificadas por Parrado et al. (2013), Bovaird et al. (2014) e Alford e Yates (2015) ao estudarem o serviço de cuidado à saúde, que apontam que as mulheres são mais propensas a mudar sua dieta, ir ao médico e participar de grupos relacionados aos cuidados com a saúde. Conforme discutido por Bovaird et al. (2014, p.15-16) é relevante considerar que a coprodução do serviço de cuidado com a saúde tem característica majoritariamente individual, o que teria levado a uma relação positiva entre o gênero feminino e este tipo de coprodução, resutlado que não se repetiu quando o autor considerou as formas coletivas de coprodução. 
Apesar de a análise não ter identificado indícios de uma relação relevante entre gênero e a coprodução, é válido ressaltar que o simples fato de mais de $80 \%$ dos sujeitos de pesquisa terem se declarado do sexo feminino já demonstra maior propensão das mulheres em participar da educação dos seus tutelados, haja vista que a coleta de dados foi realizada em reunião de pais e por meio da agenda dos estudantes, e estar na reunião de pais bem como responder a agenda são em si formas de coprodução da educação pública.

O resultado referente à relação entre idade e a coprodução, não significativo, difere dos achados de Parrado et al. (2013) - que identificaram que em serviços de segurança pública, usuários mais velhos tendem a participar mais -, de Bovaird et al. (2014) - que identificaram relação fortemente negativa entre a idade e a coprodução coletiva de diferentes serviços públicos na República Tcheca e Reino Unido, e relação positiva quanto à coprodução individual. Os achados de Bovaird et al. (2014) se mostram intrigantes, como apresentado pelos próprios autores, que sugerem que pessoas mais velhas tedem a necessitar e se engajar mais no serviço de cuidados com a saúde, que é majoritariamente coproduzido individualmente, de forma que a idade se mostra positivamente relacionada com este serviço, mas não com os outros, cuja coprodução coletiva é mais relevante.

No estudo conduzido por Alford e Yates (2015), a idade também se mostrou relevante, mas apenas quando analisadas cada forma de coprodução a parte. A coprodução individual se mostrou mais provável de ocorrer junto a certas faixas etárias, como idosos coproduzindo segurança pública ao observar a casa dos vizinhos que estão viajando ou jovens coproduzindo o cuidado com o meio ambiente ao orientar pessoas que jogam lixo na rua a não fazê-lo.

Conforme apresentado na Tabela 10 - Modelos de regressão linear com a coprodução coletiva e a coprodução individual como variáveis dependentes., a escolaridade não tem influência significativa na coprodução coletiva, mas tem na individual. Neste caso, comparativamente com os familiares com o Ensino Fundamental, foi observado que os familiares com graduação ou pós-graduação são levados a apresentar atividades de coprodução individual $(\beta=0.210 ; \mathrm{p}=0.011)$. Esse resultado vai de encontro com o identificado por Bovaird et al. (2014, p.15): indivíduos com altos níveis educacionais têm a uma visão mais ampla, e assim estão mais preocupados com questões coletivas e na suas soluções se engajam mais." Dessa forma, segundo os resutlados de Bovaird et al. (2014), quanto maior a escolaridade, maior a propensão a coproduzir coletivamente em relação a propensão a coproduzir individualmente. 
Alford e Yates (2015) não indentificaram diferença relevante entre o nível educacional do usuário do serviço e a coprodução, todavia, identificaram a relação com a ocupação, resultados semelhante ao do estudo de Parrado et al. (2013). Estes concluíram que o nível de instrução tem uma relação fraca e inconsistente com os comportamentos de coprodução de diversos setores e países, inclusíve que indivíduos graduados se mostram de alguma forma menos propensos a coproduzir - resultado contrátio ao identificado na educação pública nesta pesquisa. Parrado et al. (2013) sugerem que o nível de educação influencia mais em participações "consultivas" dos usuários quanto ao serviço, não na prestação do serviço em si, ao passo que na educação pública, a coprodução política (que mais se assemelha às participações consultivas), se mostrou influênciada negativamente pelo fato de o familiar de graduado.

Quanto à ocupação, observa-se que comparativamente com os familiares que trabalham (autônomos, servidor públicos ou empregados do Setor Privado), os dono(a)s de casa têm maiores níveis de coprodução coletiva $(\beta=0.128 ; \mathrm{p}=0.040)$ e os estudantes têm menores níveis de coprodução coletiva $(\beta=-0.155 ; \mathrm{p}=0.013)$. A ocupação não tem influência significativa na coprodução individual. A maior propensão de donos de casa a coproduzir coletivamente condiz com o achado de Bovaird et al. (2014, p.16), de que a atividade econômica não tem relação com a coprodução individual, mas que no Reino Unido "estar inativo enquanto trabalhador tem uma forte correlação com o comportamento de coprodução coletiva."

Parrado et al. (2013), apontaram que estar ativo no mercado de trabalho tem relação fraca e inconsistente com o comportamento de coprodução, tendo um efeito positivo na coprodução da segurança pública em alguns países, Alemanha e Reino Unido, e negativo na coprodução do cuidado com o meio ambiente na Dinamarca. De toda forma, o autor não avaliou sob a ótica do tipo de coprodução, individual ou coletiva.

Residir no mesmo bairro da escola não apresentou, nesta pesquisa, influência na coprodução individual, mas sim na coletiva $(\beta=0.114 ; \mathrm{p}<0.10)$ : os familiares que vivem no mesmo bairro da escola têm maiores níveis de coprodução coletiva. Uma possível razão é que a coprodução individual, na maioria dos caso, pode ser remota, ou seja, pode ser feita de casa, como nos exemplos de formas de coprodução tratados na pesquisa, ajudar o alunos na lição de casa, e pedir conselhor aos profissionais da escola, o que pode ser feito remotamente, por exempo, por telefone. Por outro lado, a coprodução coletiva da educação pública demanda, muitas vezes, a presença na escola, como no caso da participação nos eventos, execução de atividades de desenvolvimento da escola ou participação no conselho escolar. 
A literatura sobre coprodução de serviços públicos tem tratado a variável local de residência definindo-a com as opções urbano e rural, o que não se aplicou nesta pesquisa, uma vez que a representatividade das residências rurais é irrelevante na região tratada.

Parrado et al. (2013) identificaram grau de relação entre viver em áreas urbanas e coproduzir. Já Bovaird et al. (2014) indentificaram uma associação baixa e positiva no caso da coprodução individual, não apontando relação no caso da coletiva.

Quanto aos hábitos familiares, especificamente às formas de lazer, os familiares que referem a leitura e o teatro têm maiores níveis de ambos os tipos de coprodução. Ver televisão, ir ao cinema e praticar esporte não têm influência significativa na coprodução, seja coletiva ou individual.

Os pais e responsáveis que fazem planejamento das refeições, os que escrevem lista de tarefas e os realizam controle e planejamento financeiro apresentam maiores níveis de coprodução individual e coletiva. . Essas relações vão ao encontro dos resultados auferidos por Alves et al. (2013) de que tais hábitos influenciam positivamente o aprendizado possivelmente pela coprodução da educação pelos familiares. O hábito de comunicar pela escrita tem influência positiva na coprodução coletiva, mas não na individual. Por outro lado, fazer lista de compras para o supermercado tem influência positiva na coprodução individual, mas não na coletiva. As horas semanais de leitura e de interação com o estudante não influenciam nem a coprodução coletiva nem a individual.

Observa-se que as variáveis sociodemográficas e relacionadas com os hábitos familiares explicam $19.7 \%$ da variabilidade da coprodução coletiva e $24.4 \%$ da variabilidade da coprodução individual. Bovaird et al. (2014), sem incluir variáveis referentes a hábitos familiares, chegaram a um nível de explicação que variou de 7,6\% e 12,4 \% entre os diferentes países análisados, explicitando a relevância do entendimento dos hábiots familiares para a previsão de um comportamento de coprodução.

Em especial quando se trata cada forma de coprodução à parte, a previsibilidade trazida pelas váriáveis sócio-demográficas e hábitos familiares varia de 16,6\% a 32\% (conforme Tabela 6, Tabela 7 e Tabela 8), uma influência relevante, haja vista a dificuldade relatada pelos gestores escolares em prever e incentivar a coprodução de familiares. 


\section{CONCLUSÕES}

Este estudo teve como objetivo geral identificar como o governo e escolas têm fomentado o ensino fundamental público por meio do incentivo à coprodução de familiares de alunos, e como o perfil destes familiares influencia as formas de coprodução. Para alcançar o objetivo geral, foram cumpridos quatro objetivos específicos: identificar políticas de incentivo à coprodução de familiares no ensino fundamental promovidas pelos governos federal e do distrito federal; identificar as ações de incentivo à coprodução do ensino fundamental promovidas pelas escolas; identificar formas pelas quais a coprodução de familiares ocorre na oferta do ensino fundamental; e verificar a influência do perfil de familiares de alunos nas formas de coprodução.

A partir do estudo foi possível observar um foco das políticas públicas brasileiras em incentivar a coprodução da educação a partir da geração de mecanismos que obriguem os familiares a fazê-lo, mas também que obriguem a escola a garantir mecanismos formais de coprodução política - os conselhos escolares. Já as escolas, além de cumprir com as diretrizes trazidas pelos governos, tendem a lançar mão de estratégias de informação e diálogo, mas também utilizam os mecanismos legais que obrigam os familiares a participar da educação dos alunos. Essa estratégia de forçar os familiares a coproduzir é principalmente voltada a um tipo de coprodução não identificada nos estudos conduzidos por Pestoff (2007) na Europa e Ostrom (1996) na Nigéria, a coprodução de suporte básico, nas qual as famílias garantem todo cuidado necessário para que os alunos possam aprender plenamente - saúde, nutrição, higiene, suporte afetivo. O estudo explicitou que a coprodução individual - dentro da qual se enquadra o suporte básico - é influenciada principalmente pela escolaridade e hábitos familiares que aumentam o capital cultural da família, leitura e teatro - mostrando que a busca pelo aumento da instrução e cultura das famílias pode ser uma estratégia de incentivo à coprodução, e assim, de desenvolvimento do aprendizado no ensino fundamental.

Assim, esta pesquisa contribui com o entendimento da coprodução de serviços públicos ao propor um framework de coprodução de serviços públicos, que pode ser utilizado tanto para o aprofundamento das pesquisas quanto a coprodução da educação, quanto replicado para a outros serviços públicos. Também contribui ao investigar a educação pública no Brasil, mesmo serviço estudado por Pestoff (2006) na Europa e Ostrom (1996) na Nigéria, 
permitindo entender como a coprodução de serviços públicos pode se diferenciar conforme o nível de desenvolvimento econômico do país.

A coleta de dados junto a familiares de alunos se limitou ao questionário respondido pelo sujeito de pesquisa, excluindo a participação de analfabetos, e se limitou à coleta pela agenda do aluno e na reunião de pais, excluindo a participação dos familiares que menos coproduzem. Para pesquisas futuras, se mostra necessário trabalhar com entrevistas em profundidade com diversos perfis de familiares de alunos, inclusive aqueles que possuem baixo nível de instrução e renda e que, mesmo assim, estão dispostos a coproduzir, e os que não o fazem de forma alguma. Dessa forma a pesquisa abrangerá os familiares analfabetos. Além disso, se mostra necessário um esforço de ir até o familiar, garantindo a participação dos que menos coproduzem. 


\section{REFERÊNCIAS}

Alford, J. (2002). Why Do Public-Sector Clients Coproduce Toward a Contingency Theory?, Administration \& Society, 34(1):32-56.

Alford, J. (2009). Engaging public sector clients. From service delivery to co-production. New York: Palgrave Macmillian.

Alford, J., \& Yates, S. (2015). Co-Production of Public Services in Australia: The Roles of Government Organisations and Co-Producers. Australian Journal of Public Administration, 75(2):159-175.

Alford, J. (2015). The Multiple Facets of Co-Production: Building on the Work of Elinor Ostrom. Public Management Review 16 (3), 299-316.

Alves, M. T., Nogueira, M. A., Marques, C., \& de Freitas, T. (2013) Fatores Familiares e Desempenho Escolar: Uma Abordagem Multidimensional Dados. Revista de Ciências Sociais, 56(3), 571-603.

Baker, D. P., Goesling, B., \& LeTendre, G. K. (2002). Socioeconomic Status, School Quality, and National Economic Development: A Cross-National Analysis of the "Heyneman-Loxley Effect" on Mathematics and Science Achievement. Comparative Education Review, 46(3), 291-312.

Bardin, L. (2009). Análise de Conteúdo. Lisboa: Edições 70.

Bitner, M., Faranda, W., Hubbert, A., \& Zeithaml, V. (1997), Customer contributions and roles in service delivery. International Journal of Service Industry Management, 8(3), 193-205.

Bovaird, T. (2007). Beyond Engagement and Participation: User and Community Coproduction of Public Services. Public Administration Review, 67(5), 846-860.

Bovaird, T., \& Loeffler, E. (2012). From Engagement to Co-Production: The Contribution of Users and Communities to Outcomes and Public Value. International Society of Third Sector Research, 23(4), 1119-1138.

Bovaird, T., Van Ryzin, G., Loefflerand, E., \& Parrado, S. (2014). Activating Citizens to Participate in Collective Co-Production of Public Services. Journal of Social Policy, 44(1), 1-22.

Bovaird, T., Stoker, Jones, T., G., Loeffler, E., \& Rocancio, M. (2015). Activating collective co-production of public services: influencing citizens to participate in complex governance mechanisms in the UK. International Review of Administrative Sciences, 82(1), 47-68.

Brudney J. L., \& England R. E. (1983). Toward a definition of the coproduction concept. Public Administration Review, 43(1), 59-65. 
Chathoth, P. K., Altinay, L., Harrington, R.J., Okumus, F. \& Chan, E. (2013). Co-production versus co-creation: A process based continuum in the hotel service context. International Journal of Hospitality Management, 32(1), 11-20.

Christophe, M., Elacqua, G., Martinez, M., \& Araújo e Oliveira, J. (2015). Educação Baseada em Evidências: Como saber o que funciona em Educação. Brasília: Instituto Alfa e Beto.

Chubb, J. E., \& Moe, T. M. (1990) Market forces in education. American Political Science Review, 84(2), 549-567.

Constituição da república federativa do brasil de 1988. (1988). Presidência da República. Brasília. Disponível em:

<http://www.planalto.gov.br/ccivil_03/constituicao/constituicao.htm> Acesso em 12 de mai. 2016

Dadfar, H., Brege, S., Sarah, S., \& Semnani, E. (2013). Customer involvement in service production, delivery and quality: the challenges and opportunities. International Journal of Quality and Service Sciences. 5(1), 46-65.

Davis, G., \& Ostrom, E. (1991). A Public Economy Approach to Education: Choice \& CoProduction, International Political Science Review, 12(4), 313-335.

Decreto 5.209, de 17 de setembro de 2004. (2004). Altera artigos do programa Bolsa Família. Presidência da República. Brasília. Disponível em: < http://www.planalto.gov.br/ccivil_03/_ato2004-2006/2004/decreto/d5209.htm> Acessado em 12 de mai. 2016

Decreto 6.916, de 30 de julho de 2009. (2009). Altera artigos do programa Bolsa Família. Presidência da República. Brasília. Disponível em: <http://www.planalto.gov.br/ccivil_03/_Ato2007-2010/2009/Decreto/D6916.htm> Acessado em 12 de mai. 2016

Edvardsson, B., Gustafsson, A., Kristensson, P., \& Witell, L. (2010). Costumer integration in service innovation. Handbook of innovation and services, Windrum P., \& Garcia-Goni, M. (eds); Springer US.

Etgar, M. (2008). A descriptive model of the consumer co-production process, Journal of the Academy of Marketing Science, 36(1), 97-108.

Fundo Nacional De Desenvolvimento Da Educação Básica (2010). Resolução $n^{o} 3$, de $1^{\circ}$ de abril de 2010. Brasília. Disponível em < http://portal.mec.gov.br/index.php?option=com_docman\&view=download\&alias=5120resolucao10-programa-escola-acessivel-14052010\&category_slug=maio-2010pdf\&Itemid=30192 > Acessado em 10 de mai. 2016.

Gallouj, F., \& Weinstein, O. (1997). Innovation in services, Research Policy, 26(4-5), 537556.

Gamoran, A., \& Long, D. A. (2007). Equality of educational opportunity: A 40 year retrospective. En $\mathrm{R}$. Teese, S. Lamb, e M. DuruBellat, International studies in educational inequality, theory and policy (pp. 23-48). Dordecht, Netherlands: Springer. 
Governo do Distrito Federal. (2014). Relatório de gestão e políticas públicas 2011-2014, Brasília. Disponível em:

<http://www.cre.se.df.gov.br/ascom/documentos/suplav/relatorio_gestao_sedf_2011_20 14.pdf> Acesso em 10 de mai. 2016.

Governo do Distrito Federal. (2015a). Regimento Escolar da Rede Pública de Ensino do Distrito Federal, $6^{\circ}$ Ed, Brasília. Disponível em: < http://agenciabrasilia.df.gov.br/wpconteudo/uploads/2016/10/regimento-escolar-rede-publica-de-ensino-df.pdf > Acesso em 10 de mai. 2016.

Governo do Distrito Federal. (2015b). Relatório de Gestão SEEDF 2015, Brasília. Disponível em: < http://www.cre.se.df.gov.br/ascom/documentos/Relatorio_Anual_2015.pdf > Acesso em 10 de mai. 2016.

Governo do Distrito Federal. (2015c). Planejamento estratégico da SEEDF 2015-2018, Brasília. Disponível em: < http://www.cre.se.df.gov.br/ascom/documentos/suplav/planejamento_estrategico_mar16. pdf > Acesso em 10 de mai. 2016.

Governo do Distrito Federal. (2015d). Projeto Político Pedagógico Professor Carlos Mota, Brasília. Disponível em:

http://www.cre.se.df.gov.br/ascom/documentos/ppp_professor_carlos_mota.pdf Acesso em 10 de mai. 2016.

Hair, J.F., Black, W., Babin, B., Anderson, R.E., \& Tatham, R.L. (2005). Multivariate data analysis (5th ed.). Upper Saddle River, NJ: Prentice Hall.

Lei Distrital no 449 de 17 de maio de 1993. (1993). Brasília. Governo do Distrito Federal. Disponível em:

http://www.tc.df.gov.br/SINJ/Arquivo.ashx?id_norma_consolidado=48408> Acessado em 10 de mai. 2016.

Lei ${ }^{\circ}$ 9.394, de 20 de dezembro de 1996. (1996). Estabelece as diretrizes e bases da educação nacional. Presidência da República. Brasília. Disponível em: https://www.planalto.gov.br/ccivil_03/Leis/L9394.htm>. Acessado em 12 de mai. de 2016.

Lei $\mathrm{n}^{\circ}$ 8.069, d 13 de junho de 1990. (1990). Dispõe sobre o Estatuto da Criança e do Adolescente. Presidência da República. Brasília. Disponível em: <https://www.planalto.gov.br/ccivil_03/leis/L8069.htm> Acessado em 12 de mai. de 2016.

Lei ${ }^{\circ} 10.836$ de 9 de janeiro de 2004. (2004a). Cria o programa Bolsa família. Presidência da República. Brasília. Disponível em: https://www.planalto.gov.br/ccivil_03/Leis/L10.836.htm> Acessado em 12 de mai. de 2016.

Lei $n^{\circ} 11.947$, de 16 de junho de 2009. (2009b). Dispõe sobre o atendimento à alimentação escolar e Programa Dinheiro Direto na Escola. Presidência da República. Brasúlia. Disponível em: < http://www.planalto.gov.br/ccivil_03/_ato20072010/2009/lei/l11947.htm > Acessado em 12 de mai. 2016 
Loeffler, E., Parrado, S., Bovaird, T., \& Van Ryzin, G. (2008). If You Want to Go Fast, Walk Alone. If You Want to Go Far, Walk Together. Citizens and the Co-Production of Public Services. Paris: French Ministry of the Treasury.

Marôco, J. (2011). Análise Estatística com o SPSS Statistics. 5 ${ }^{\mathrm{a}}$ ed. Pêro Pinheiro: Editora Report Number.

Ministério da Educação (2014). Manual de orientação para constituição de unidade executora própria. Brasília. Disponível em: < http://www.fnde.gov.br/arquivos/category/191consultas?download=9059: manual-de-orientacao-para-constituicao-de-unidadeexecutora-propria-07082014 > Acessado em 12 de mai. 2016

Osborne, S. P., \& Strokosch, K. (2013). It Takes Two to Tango? Understanding the CoProduction of Public Services by Integrating the Services Management and Public Administration Perspectives. British Journal of Management, 24(1), S31-S47.

Ostrom V., \& Ostrom E. (1977) Public goods and public choices. In: Savas, ES (ed.) Alternatives for Delivering Public Services: Toward Improved Performance. Boulder, CO: Westview Press, 7-49.

Ostrom, E., Parks, R. B., Whitaker, G. P., \& Percy, S. L. (1978). The Public Service Production Process: A Framework for Analyzing Police Services. Policy Studies Journal 7(S1), 381-389.

Ostrom, E. (1996). Crossing the Great Divide: Coproduction, Synergy, and Development. World Development, 24(6), 1073-1087.

Ostrom, E. (2009). Social Cooperation in Collective-Action Situations. In Contributions of Cooperative Self-Help to Economic and Social Development. Hans Jurgen Rosner and Frank Schulz-Nieswandt, eds. Berlin: LIT Verlag. (Neue Kolner Genossenschaftswissenschaft, Bd. 5).

Parrado, S., Van Ryzin, G., Bovaird, T., \& E. Loeffler. (2013). Correlates of Co-Production: Evidence from a Five-Nation Survey of Citizens. International Public Management Journal, 16(1), 85-112.

Parks, R., Baker, P., Kiser, L., Oakerson, R., Ostrom, E., Ostrom, V., Percy, S. L., Vandivort, M. B., Whitaker, G. P., \& Wilson, R. (1981). Consumers as Co-Producers of Public Services: Some Economic and Institutional Considerations. Policy Studies Journal, 9(7), 1001-1011.

Pestoff, V. (2006); Citizens as Co-Producers of Welfare Services: preschool services in eight European countries, Public Management Review, 8(4), 503-520

Pestoff, V. (2009). Towards a Paradigm of Democratic Participation: Citizen Participation and Co-Production of Personal Social Services in Sweden. Annals of Public and Cooperative Economics, 80(2), 197-224.

Pestoff, V. (2012). New Public Governance, CoProduction and Third Sector Social Services in Europe: Crowding In and Crowding Out'. In V. Pestoff, T. Brandsen and B. 
Verschuere (eds.), New Public Governance, the Third Sector and Co-Production, 361380. New York: Routledge.

Pestoff, V. (2014). Collective action and the sustainability of co-production. Public Management Review, 16(3), 383-401.

Rosentraub, M. S., \& Sharp, E. B. (1981). Consumers and producers of social services: Coproduction and the level of social services. Southern Review of Public Administration, 4(4), 502-539.

Sharp, E. (1980). Toward a new understanding of urban services and citizen participation: The coproduction concept. Midwest Review of Public Administration, 14(2), 105-118.

Thaler, R., \& Sunstein, C. (2009) Nudge: Improving Decisions about Health, Wealth, and Happiness. Chicago: Penguim editon.

Thiry-Cherques, H. R. (2009) Saturação em pesquisa qualitativa: estimativa empírica de dimensionamento. Revista Brasileira de Pesquisas de Marketing (PMKT), 9(1), 20-27.

Troye, S.V., \& Supphellen, M. (2012), Consumer participation in coproduction: "I made it myself" effects on consumers' sensory perceptions and evaluations of outcome and input product, Journal of Marketing, 76(2), 33-46.

Verschuere, B., Brandsen, T., \& Pestoff, V. (2012). Co-Production: The State of the Art in Research and the Future Agenda. Voluntas: International Journal of Voluntary and Nonprofit Organizations, 23(4), 1083-1101.

Whitaker, G. (1980). Coproduction: Citizen Participation in Service Delivery. Public Administration Review, 40(2), 240-246.

Windrum P., \& Garcia-Goni, M. (2008). A neo-Schumpeterian model of health services innovation. Research Policy, 34(4), 649-672 


\section{Apêndices}

\section{Apêndice A - TCLE e Roteiro da Entrevista}

\section{Termo de Consentimento Livre e Esclarecido - Entrevista}

$\mathrm{O}$ (a) senhor(a) está convidado(a) a participar de uma pesquisa sobre Participação de Familiares na educação pública, elaborada pela Professora Doutora Josivania Silva Farias, do Programa de Pósgraduação em Administração da UnB, e pelo mestrando em Administração Guilherme Soares com o objetivo de entendimento dos fatores relacionados à participação das famílias na educação dos alunos. Esta pesquisa se endereça a gestores de escolas públicas do Distrito Federal. A sua participação ocorrerá por meio de entrevista, para a qual utilizaremos um roteiro de perguntas e será realizada na própria escola em data(s) e horário(s) a ser(em) combinado(s) com o(a) $\operatorname{Sr}(a)$, estimando-se como tempo de duração para sua realização um período entre 20 e 45 minutos. Informamos que o(a) Senhor(a) pode se recusar a responder quaisquer perguntas caso não se sinta à vontade, podendo desistir de participar da pesquisa em qualquer momento de sua ocorrência, sem nenhum prejuízo para o(a) senhor(a). Sua participação é voluntária e não há gratificação por sua colaboração. Os resultados da pesquisa poderão ser divulgados pela Universidade de Brasília (UnB).

Precisamos de sua sinceridade nas respostas. Lembre-se de que não há respostas certas ou erradas. Todas são corretas desde que correspondam ao que você pensa.

Para esclarecer dúvidas e fazer comentários a qualquer momento ou mesmo para conhecer os resultados desta pesquisa, não hesite em contatar: guilhermefsoares@ gmail.com.

Este documento foi elaborado em duas vias: uma ficará com o pesquisador responsável e a outra com o sujeito da pesquisa.

Nome / assinatura

Pesquisador Responsável

Nome e assinatura

Brasília, de de 


\title{
Roteiro de entrevista com gestores de escolas de ensino fundamental do Distrito Federal
}

\author{
Abertura: \\ Explicação sobre a pesquisa e solicitação de informações básicas: \\ 1. Nome, gênero, idade. \\ 2. Experiência no serviço de educação pública (tempo e função). \\ 3. Função atual, titulação/formação

\section{Perguntas sobre o tema:}

\section{Mecanismos de incentivo} \\ 4. A escola possui mecanismos formais de incentivo à participação da família, como \\ conselho escolas, associação de pais e professores etc.? \\ 5. Descreva estratégias (ou formas) de incentivo. \\ 6. Os objetivos dos incentivos têm sido alcançados nesta escola? \\ 7. A quais fatores você atribui a motivação de familiares a participar da oferta do ensino \\ fundamental na rede pública do DF?

\section{Formas de participação} \\ 8. Qual a importância da participação de familiares no aprendizado? \\ 9. Familiares de alunos participam do processo educacional? \\ 10. Em caso positivo, quais as formas pelas quais os familiares têm participado da \\ educação dos alunos? \\ 11. Descreva as formas de participação quanto à periodicidade, tempo de ocorrência, \\ esforço e custo para os familiares e relevância para a escola.
}




\section{Apêndice B - Questionário de entendimento do perfil e formas de coprodução da educação para aplicação junto a familiares}

\section{Apresentação}

Você está convidado (a) a participar de uma pesquisa sobre Participação de Familiares na educação pública, elaborada pela Professora Doutora Josivania Silva Farias, do Programa de Pósgraduação em Administração da UnB, e pelo mestrando em Administração Guilherme Soares com o objetivo de entendimento dos fatores relacionados à participação das famílias na educação dos alunos.

Esta pesquisa se endereça a adultos responsáveis por alunos que estejam matriculados entre o primeiro e quinto ano das Escolas Classe do Distrito Federal. O tempo estimado para responder às questões é entre 10 a 15 minutos.

Precisamos de sua sinceridade nas respostas. Lembre-se de que não há respostas certas ou erradas. Todas são corretas desde que correspondam ao que você pensa. É importante ressaltar que as questões sobre o seu perfil sociodemográfico buscam apenas caracterizar a amostra da pesquisa. Por isto, os dados desta pesquisa são confidenciais e serão utilizados para fins acadêmicos, de modo agrupado, não sendo possível identificar os sujeitos participantes individualmente.

Para esclarecer dúvidas e fazer comentários a qualquer momento ou mesmo para conhecer os resultados desta pesquisa, não hesite em contatar: guilhermefsoares@gmail.com.

Agradecemos sua colaboração! 


\section{Termo de Consentimento Livre e Esclarecido - TCLE - Questionário}

O(a) senhor(a) está convidado(a) a participar de uma pesquisa sobre Participação de Familiares na educação pública, elaborada pela Professora Doutora Josivania Silva Farias, do Programa de Pósgraduação em Administração da UnB, e pelo mestrando em Administração Guilherme Soares com o objetivo de entendimento dos fatores relacionados à participação das famílias na educação dos alunos. Esta pesquisa se endereça a adultos responsáveis por alunos que estejam matriculados entre o primeiro e quinto ano das Escolas Classe do Distrito Federal. A sua participação ocorrerá por meio de um questionário, estimando-se como tempo de duração para sua realização um período entre 10 e 15 minutos. Informamos que o(a) Senhor(a) pode se recusar a responde-lo caso não se sinta à vontade, podendo desistir de participar da pesquisa em qualquer momento de sua ocorrência, sem nenhum prejuízo para o(a) senhor(a). Sua participação é voluntária e não há gratificação por sua colaboração. Os resultados da pesquisa poderão ser divulgados pela Universidade de Brasília (UnB).

Precisamos de sua sinceridade nas respostas. Lembre-se de que não há respostas certas ou erradas. Todas são corretas desde que correspondam ao que você pensa. É importante ressaltar que as questões sobre o seu perfil sociodemográfico buscam apenas caracterizar a amostra da pesquisa. Por isto, os dados desta pesquisa são confidenciais e serão utilizados para fins acadêmicos, de modo agrupado, não sendo possível identificar os sujeitos participantes individualmente.

Para esclarecer dúvidas e fazer comentários a qualquer momento ou mesmo para conhecer os resultados desta pesquisa, não hesite em contatar: guilhermefsoares@ gmail.com.

Este documento foi elaborado em duas vias: uma ficará com o pesquisador responsável e a outra com o sujeito da pesquisa.

Nome / assinatura

Pesquisador Responsável

Nome e assinatura

Brasília, de de 


\section{Parte I - Dados sociodemográficos}

1. Idade: (digite apenas os anos, sem os meses):

2. Gênero: ( )Masculino ( )Feminino

3. Qual seu nível de escolaridade? Indique a opção já concluída:
( ) Ensino fundamental
( ) Ensino médio
( ) Graduação
( ) Pós-graduação

4. Qual é a sua ocupação?
( ) Autônomo
( ) Servidor Público
( ) Empregado do Setor Privado
( ) Estudante
( ) Aposentado
( ) Desempregado
( ) Dono(a) de casa (familiar que é 'do lar').
( ) Outro. Cite:

5. Em que região administrativa você reside?
( ) Plano Piloto
( ) Gama
( ) Riacho Fundo
( ) Taguatinga
( ) Brazlândia
( ) Lago Norte
( ) Sobradinho
( ) Candangolândia
( ) Planaltina
( ) Paranoá
( ) Núcleo Bandeirante
( ) Águas Claras
( ) Riacho Fundo II
( ) Sudoeste/Octogonal
( ) Ceilândia
( ) Varjão
( ) Park Way
( ) Guará
( ) SCIA
( ) Cruzeiro
( ) Sobradinho II
( ) Samambaia
( ) Jardim Botânico
( ) Santa Maria
( ) Itapoã
( ) São Sebastião
( ) SIA
( ) Recanto das Emas
( ) Vicente Pires
( ) Fercal
( ) Lago Sul
( ) Fora do Distrito Federal

6. Em que região administrativa se localiza a escola do(s) aluno(s) pelo(s) qual(is) você é responsável?
( ) Plano Piloto
( ) Riacho Fundo
( ) Gama
( ) Lago Norte
( ) Taguatinga
( ) Candangolândia
( ) Brazlândia
( ) Águas Claras
( ) Sobradinho
( ) Riacho Fundo II 
( ) Planaltina

( ) Paranoá

( ) Núcleo Bandeirante

( ) Ceilândia

( ) Guará

( ) Cruzeiro

( ) Samambaia

( ) Santa Maria

( ) São Sebastião

( ) Recanto das Emas

( ) Lago Sul
( ) Sudoeste/Octogonal

( ) Varjão

( ) Park Way

( ) SCIA

( ) Sobradinho II

( ) Jardim Botânico

( ) Itapoã

( ) SIA

( ) Vicente Pires

( ) Fercal

( ) Fora do Distrito Federal

\section{Parte II - Hábitos familiares}

7. Quais formas de lazer da família
( ) Leitura
( ) Cinema
( ) Teatro
( ) Televisão
( ) Esporte
( ) Outro. Cite:

8. A família possui o hábito de se comunicar pela escrita, com bilhetes, mensagens etc.?

( ) Sim ( ) Não

9. A família possui quais dessas práticas?

Fazer lista de compras para ir ao supermercado ( ) Sim ( ) Não

Fazer um planejamento das refeições listando o que será servido ( ) Sim ( ) Não

Escrever Lista de tarefas a fazer para organizar e controlar as atividades domésticas ( ) $\operatorname{Sim}$ ( ) Não

Realizar controle e planejamento financeiro, contendo a renda familiar e as diversas despesas.

( ) Sim ( ) Não

10. Quantas horas em médias por semana os membros da família gastam lendo? __ horas (digite apenas as horas, sem minutos).

11. Qual é a sua expectativa de escolaridade do estudante que está sob sua responsabilidade?

( ) Ensino fundamental

( ) Ensino médio

( ) Graduação (Faculdade)

( ) Pós-graduação

12. Quantas horas o aluno sob sua responsabilidade interage com a família por semana? horas (digite apenas as horas, sem minutos).

13. Você conhece alguma forma de apoiar o aluno? ( ) Sim ( ) Não

14. Se a resposta anterior foi "Sim", cite as formas de apoio ao aluno que o senhor (a) conhece. 
Parte III - Formas de coprodução entre família e escola na oferta de educação

\section{fundamental pública}

15. A quais das atividades a seguir você se dedica voluntariamente para ajudar a tornar a educação melhor? (você poderá assinalar mais de uma opção).

Executar atividades de desenvolvimento da escola (trabalhar em reformas, ( ) eventos)

Doar recursos financeiros ou de outros tipos (materiais etc.)

Participar de festas e eventos promovidos pela escola

Apoiar na elaboração das tarefas de casa

Pedir conselhos da escola sobre como auxiliar o filho

Participar do Conselho escolar ou Associação de Pais e Professores 